2. To: (Receiving Organization)

Distribution

3. From: (originating organization) Characterization Support

5. Proi./Prog./Dept./Div.:

6. cog. Engr.:

B. C. Simpson

WM/Characterization

8. Originator Remarks:

Tank Characterization Report for Double-Shell Tank 241-AP102. This report contributes to the fulfillment of TPA Milestone M-44-05

11. Receiver Renarks:

13. Permit/Permit Applicstion No.: NA

14. Required Response Date:

Aug. 31, 1994

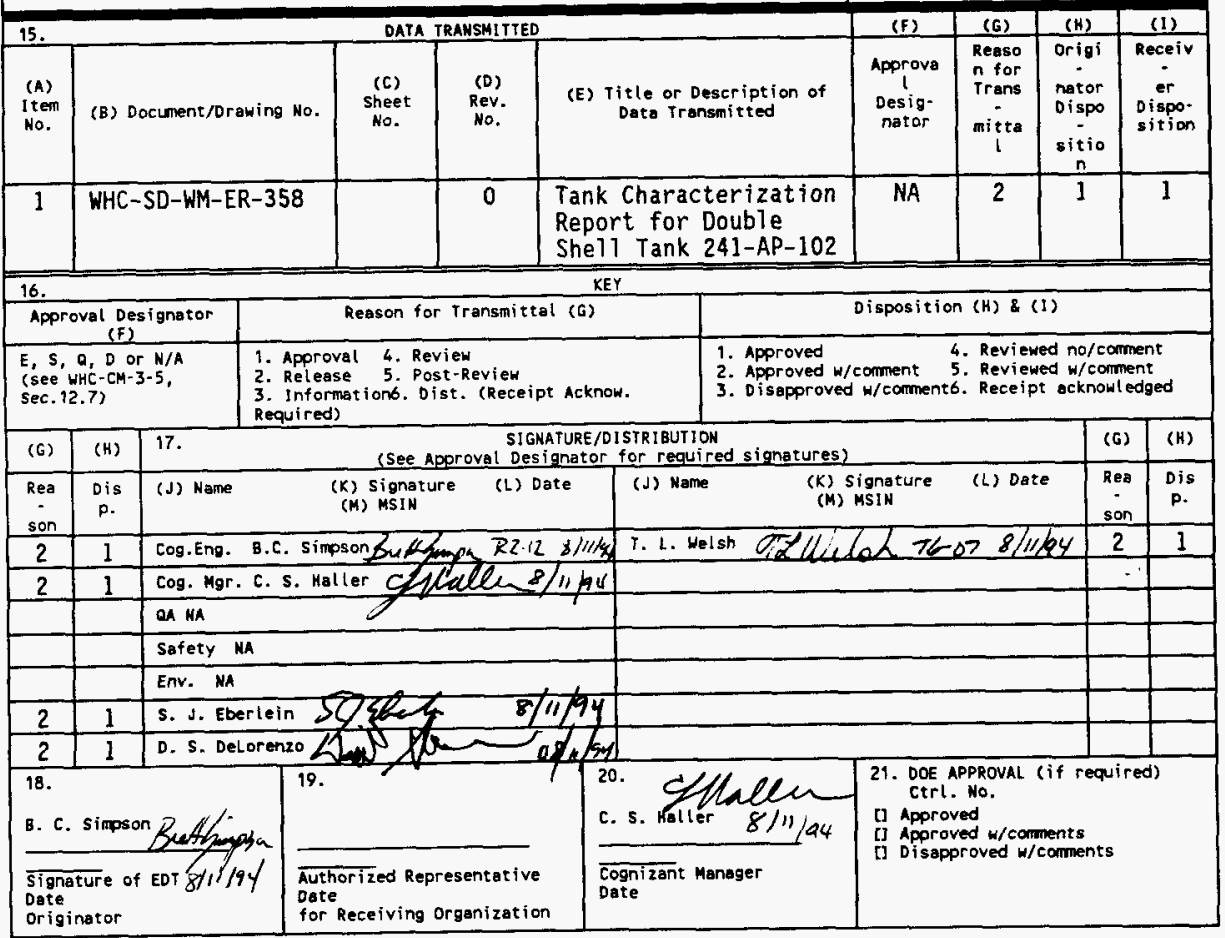

BD-7400-172-2 (04/94) GEF097 
THSPAGE NTENTIONALULET BUNH 


\section{RELEASE AUTHORIZATION}

Document Number: WHC-SD-WH-ER-358 REVISION 0

Document Title: Tank Characterization Report for Double-Shell Tank 241-AP-102

Release Date: $\quad 9 / 6 / 94$

This document was reviewed following the procedures described in WHC-CM-3-4 and is:

APPROVED FOR PUBLIC RELEASE

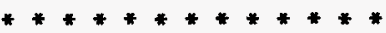

WHC Information Release Administration Specialist:

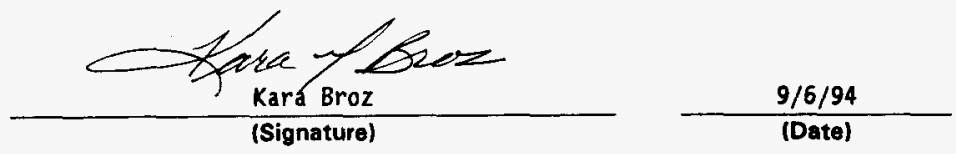


THIS PAGE INTENTIONALLY LET BLANK 


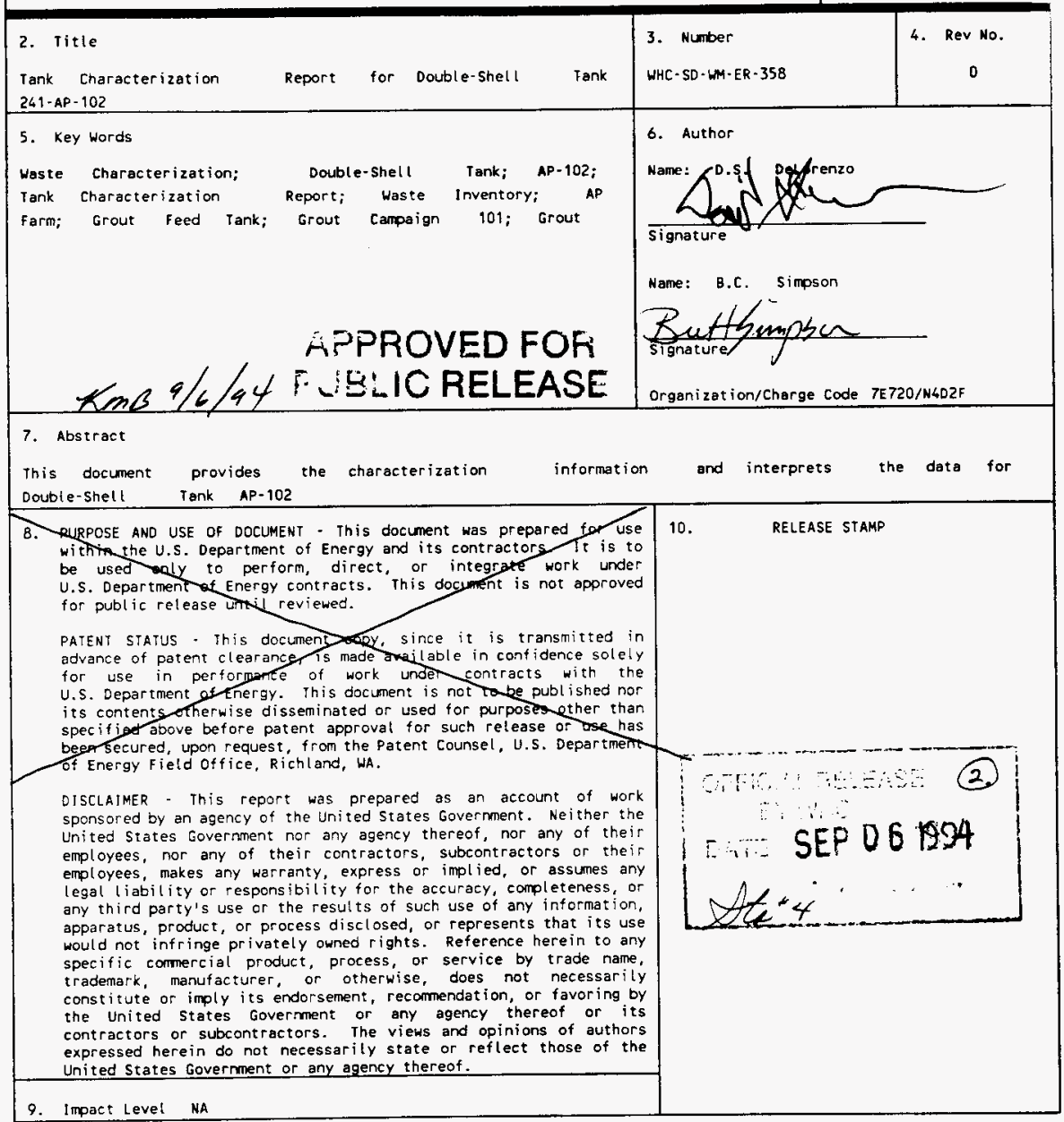




$$
\text { THIS PAGE INTENTIONALLY LEFT BLANK }
$$




\title{
Tank Characterization Report for Double-Shell Tank 241-AP-102
}

\author{
D. S. De Lorenzo \\ A. T. DiCenso \\ L. C. Amato \\ M. I. Weyns-Rollosson \\ D. J. Smith \\ Los Alamos Technical Associates, Incorporated
}

\author{
B. C. Simpson \\ T. L. Welsh \\ Westinghouse Hanford Company
}

Date Published

August 1994

Prepared for Westinghouse Hanford Company by Los Alamos Technical Associates 8633 Gage Bivd.

Kennewick, WA 99336 
THIS PAGE NTENTONALLYLETT BLANK 
WHC-SD-WM-ER-358 REV 0

\section{EXECUTIVE SUMMARY}

Double-Shell Tank 241-AP-102 is a radioactive waste tank most recently sampled in April of 1993. Sampling and characterization of the waste in Tank 241-AP-102 fulfills Milestone M-44-05 of the Hanford Federal Facility Agreement and Consent Order.

Tank 241-AP-102, located in the 200 East Area AP Tank Farm, was constructed and went into service in 1986 as the feed tank for the Grout Treatment Facility. With the cancellation of the Grout Program, the final disposal of the waste in Tank 241-AP. 102 will be as high- and low-level glass fractions. Tank 241-AP-102 has a operational capacity of $1,140,000$ gallons and currently contains 1,104,000 gallons of concentrated phosphate and dilute noncomplexed waste. All of the waste is liquid. The tank is not classified as a Watch List tank and is considered to be sound. There are no Unreviewed Safety Questions associated with Tank 241-AP-102 at this

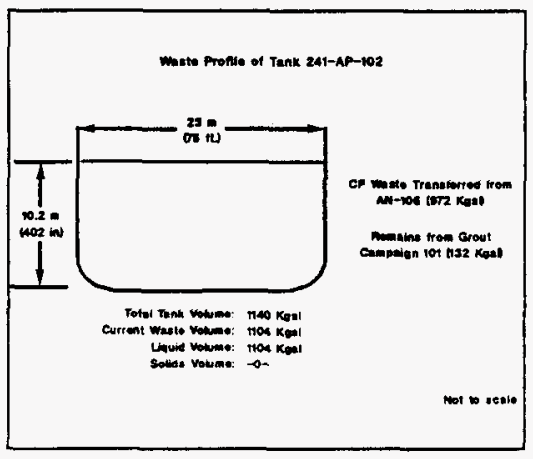
time.

The waste in Tank 241-AP-102 exists as an aqueous solution of inorganic salts and radionuclides, with limited amounts of organic complexants. At current in-tank temperatures (above $80^{\circ} \mathrm{F}$, no solids form. The most prevalent solubie analytes include aluminum, phosphorus, potassium, sodium, chloride, hydroxide, nitrate, nitrite, phosphate, and sulfate. The major radionuclide constituent is ${ }^{137} \mathrm{Cs}$. The calculated $\mathrm{pH}$ of 13.7 is above the Resource Conservation and Recovery Act established limit in corrosivity. In addition, cadmium and chromium concentrations were found in concentrations greater than their regulatory thresholds. Careful regard should be given to any future evaporation processing of this waste. Substantial reduction of the water content of the waste could increase the TOC levels of concentrations of concern to processing. Comparisons to established limits of concern for selected analytes can be made by referring to the Tank Characterization Reference Guide (De Lorenzo et al., 1994).

The results of the analyses have been compared to the dangerous waste codes in the Washington Dangerous Waste Regulations (WAC 173-303). This assessment was conducted by comparing tank analyses against dangerous waste characteristics (" $D$ " waste codes) and against state waste codes. It did not include checking tank analyses against " $U$ ", "P", " $F$ ", or " $K$ " waste codes since application of these codes is dependent on the source of the waste and not on particular constituent concentrations. The results indicate that the waste in this tank is adequately described in the Dangerous Waste Permit Application for the Double-Shell Tank System; this permit is discussed in the Tank Characterization Reference Guide (De Lorenzo, et al., 1994). 


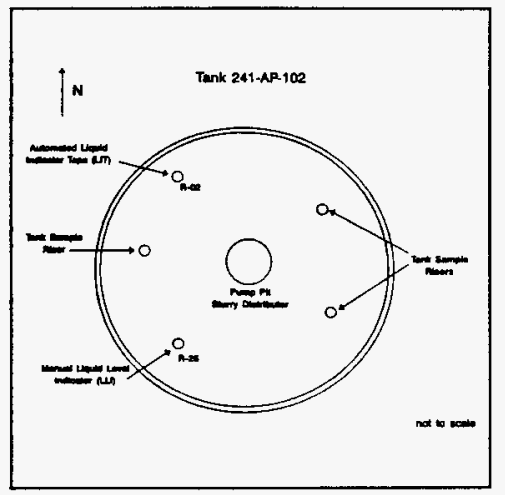

\begin{tabular}{|c|c|}
\hline \multicolumn{2}{|c|}{ TANK 24i-AP-102 } \\
\hline \multicolumn{2}{|c|}{ TANK DESCRIPTION } \\
\hline Type: & Double-Sheil \\
\hline Constructed: & 1986 \\
\hline In Service: & 1986 \\
\hline Diameter: & $75^{\prime}(23 \mathrm{~m})$ \\
\hline Usable Depth: & $35^{\prime}(10.7 \mathrm{~m})$ \\
\hline Capacity: & $\begin{array}{l}1,140,000 \mathrm{gal} \\
(4,320,000 \mathrm{~L})\end{array}$ \\
\hline Bottom Shape: & Flat \\
\hline \multirow[t]{2}{*}{$\begin{array}{l}\text { Hanford } \\
\text { Coordinates: }\end{array}$} & $40.666^{\circ}$ North \\
\hline & $46.968^{\circ}$ West \\
\hline Ventilation: & Operating Exhauster \\
\hline \multicolumn{2}{|c|}{ TANK STATUS: as of April, 1994} \\
\hline Contents: & Concentrated Phosphate \\
\hline Total Waste: & $\begin{array}{l}1,104,000 \mathrm{gal} \\
(4,195,000 \mathrm{~L})\end{array}$ \\
\hline Liquid Volume: & $\begin{array}{l}1,104,000 \mathrm{gal} \\
(4,195,000 \mathrm{~L})\end{array}$ \\
\hline $\begin{array}{l}\text { Drainable Interstitial } \\
\text { Liquid: }\end{array}$ & -0 \\
\hline $\begin{array}{l}\text { Manual Tape } \\
\text { Surface Level }\end{array}$ & 401 inches \\
\hline FIC Surface Level: & Out of Service $1 / 27 / 93$ \\
\hline Integrity Category: & Sound \\
\hline
\end{tabular}

\begin{tabular}{|c|c|c|}
\hline \multicolumn{3}{|c|}{$\begin{array}{l}\text { Double-Shell Tank } 241-A P-102 \\
\text { Concentrations and inventorles for Critical Lst Analytes }\end{array}$} \\
\hline Total Tank Volume & \multicolumn{2}{|c|}{$1,140,000$ gallons $(4,320,000 \mathrm{~L})$} \\
\hline $\begin{array}{l}\text { Total Waste Volume and } \\
\text { Mass }\end{array}$ & \multicolumn{2}{|c|}{ 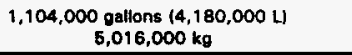 } \\
\hline Liquid Volume and Mass & \multicolumn{2}{|c|}{$\begin{array}{c}1,104,000 \text { gallons }(4,180,000 \mathrm{~L}) \\
5,016,000 \mathrm{~kg}\end{array}$} \\
\hline \multicolumn{3}{|l|}{ Ptixsical Properties } \\
\hline Density & \multicolumn{2}{|c|}{$1.20 \mathrm{~g} / \mathrm{cm}^{3}$} \\
\hline $\mathrm{H}_{2} \mathrm{O}$ & \multicolumn{2}{|c|}{$75.0 \mathrm{wt} \% 3,762,000 \mathrm{~kg}$ inventory } \\
\hline Temperature & \multicolumn{2}{|c|}{$82^{\circ} \mathrm{F}$ (end of December, 1993) } \\
\hline $\mathrm{pH}$ & \multicolumn{2}{|c|}{13.7} \\
\hline Estimated Heat Load & \multicolumn{2}{|c|}{$4.60 \mathrm{~kW}$} \\
\hline $\begin{array}{l}\text { Chemicel } \\
\text { Constituents }\end{array}$ & $\begin{array}{l}\text { Averege } \\
\text { Concentration }\end{array}$ & $\begin{array}{l}\text { Butik } \\
\text { Invontory }\end{array}$ \\
\hline Al (Aluminum) & $0.97 w t \%$ & $48,500 \mathrm{~kg}$ \\
\hline P (Phosphorus) & $0.26 w t \%$ & $12,800 \mathrm{~kg}$ \\
\hline $\mathrm{K}$ (Potassium) & $0.11 w t \%$ & $5,390 \mathrm{~kg}$ \\
\hline $\mathrm{Na}$ (Sodium) & $8.50 w+\%$ & $426,000 \mathrm{~kg}$ \\
\hline $\mathrm{CO}_{3}{ }^{2}$ (Carbonate) & $2.23 w+\%$ & $112,00 \mathrm{~kg}$ \\
\hline Cl' (Chloride) & $0.24 w t \%$ & $12,100 \mathrm{~kg}$ \\
\hline $\mathrm{OH}^{\circ}$ (Hydroxide) & $0.76 w t \%$ & $38,200 \mathrm{~kg}$ \\
\hline $\mathrm{NO}_{3}{ }^{\circ}$ (Nitrate) & $6.52 w \%$ & $327,000 \mathrm{~kg}$ \\
\hline $\mathrm{NO}_{2}^{-}$(Nitrite) & $3.17 w t \%$ & $159,000 \mathrm{~kg}$ \\
\hline $\mathrm{PO}_{4}{ }^{3-}$ (Phosphate) & $0.97 w \%$ & $48,500 \mathrm{~kg}$ \\
\hline $\mathrm{SO}_{4}=$ (Sulfate) & $0.38 w+\%$ & $19,800 \mathrm{~kg}$ \\
\hline Total Organic Carbon & $0.27 w \pi$ & $13.700 \mathrm{~kg}$ \\
\hline \multicolumn{3}{|l|}{ Radionuclides } \\
\hline Total Plutonium & $<0.177 \mu \mathrm{Ci} / \mathrm{L}$ & $<00466 \mathrm{~kg}$ \\
\hline Total Uranium & $3.85 \mathrm{E}-04 \mathrm{wt} \%$ & $19.3 \mathrm{~kg}$ \\
\hline${ }^{137} \mathrm{Cs}$ & $228,000 \mu \mathrm{Ci} / \mathrm{L}$ & 953,000 \\
\hline Heat Generation & $\cdots$ & $4.48 \mathrm{~kW}$ \\
\hline
\end{tabular}




\section{CONTENTS}

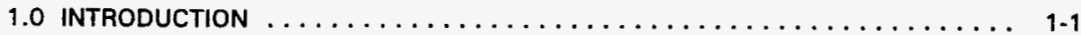

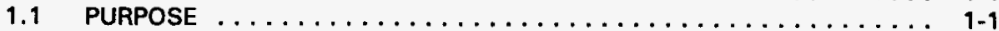

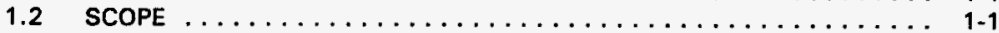

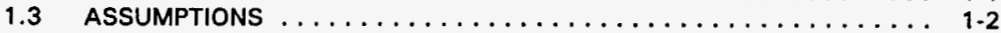

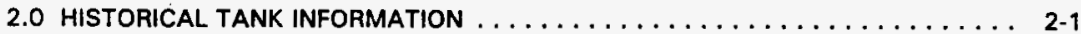

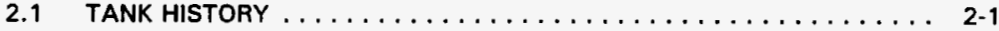

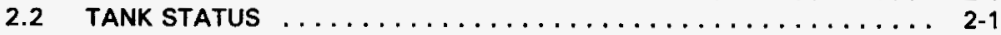

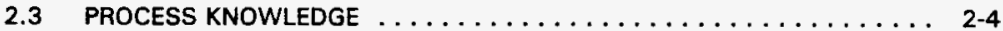

2.4 HISTORICAL ESTIMATION OF THE CONTENTS OF TANK 241-AP-102 $\ldots$ 2-6

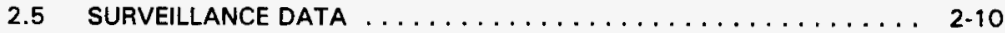

2.5.1 Surface Level Readings ................. 2-10

2.5.2 Internal Tank Temperatures ................ 2-10

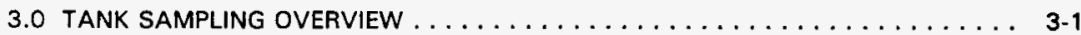

3.1 DESCRIPTION OF SAMPLING EVENT $\ldots \ldots \ldots \ldots \ldots \ldots \ldots \ldots \ldots \ldots \ldots$

3.2 SAMPLE NUMBERS AND REQUESTED ANALYTES $\ldots \ldots \ldots \ldots \ldots \ldots .1$

4.0 SAMPLE HANDLING AND ANALYTICAL SCHEME $\ldots \ldots \ldots \ldots \ldots \ldots \ldots \ldots$

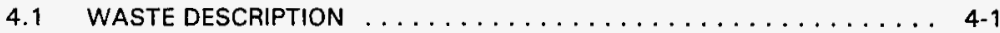

4.2 HOLD TIME CONSIDERATIONS .................. 4-1

4.2.1 WHC - Process and Analytical Laboratories ... . . . . . . . . . 4-1

4.2.2 Pacific Northwest Laboratory - Analytical Chemistry Laboratory . . 4-2

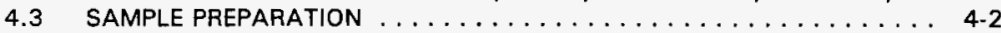

4.3.1 Adjustments Due to Solid Precipitate . . . . . . . . . . . 4-2

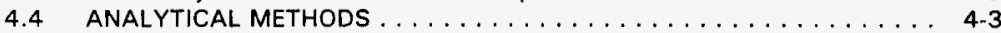

4.4.1 Physical Tests . . . . . . . . . . . . . . . . 4-3

4.4.2 Homogeneity of Waste . . . . . . . . . . . . . 4-3

4.4.3 Chemical and Radionuclide Constituent Analysis .......... 4.4

4.4.4 Volatile and Semivolatile Organic Constituent Analysis ..... . . . 4-5

4.4.5 Preparation of Composite Sample . . . . . . . . . . . . . 4-5

4.4 .6 Grout Product Tests . . . . . . . . . . . . . . . . 4-5

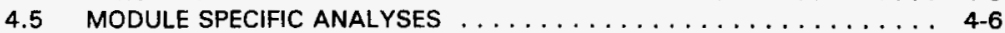

5.0 ANALYTICAL RESULTS AND WASTE INVENTORY $\ldots \ldots \ldots \ldots \ldots \ldots \ldots$

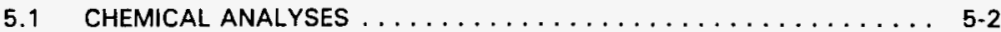

5.1 .1 Elemental Constituents . . . . . . . . . . . . . 5-2

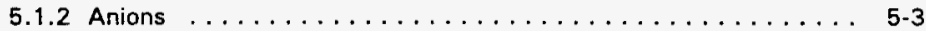

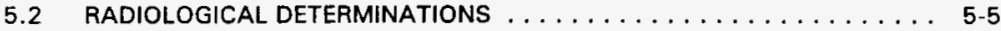

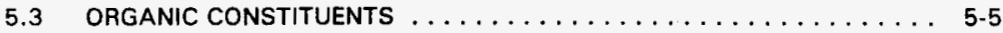

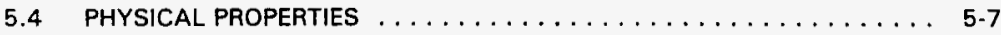

5.4.1 Specific Gravity, Percent Water, and pH . . . . . . . . . 5-7

5.4 .2 Rheology ......................... 5-7

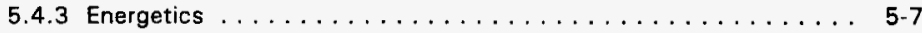

5.5 DATA PRESENTATION $\ldots \ldots \ldots \ldots \ldots \ldots \ldots \ldots \ldots \ldots \ldots$

LATA-TCR-9401, Rev. 1 
6.0 ANALYTICAL RESULTS INTERPRETATION . . . . . . . . . . . . 6-1

6.1 TANK WASTE PROFILE . . . . . . . . . . . . . . . . 6-1

6.2 WASTE SUMMARY AND CONDITIONS $\ldots \ldots \ldots \ldots \ldots \ldots \ldots \ldots$

6.2.1 In-Tank Chemistry ..................... 6-1

6.2.2 Regulatory Limits . . . . . . . . . . . . . . . 6.1

6.3 PROGRAM ELEMENT SPECIFIC ANALYSES $\ldots \ldots \ldots \ldots \ldots \ldots \ldots \ldots .2$

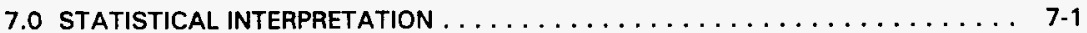

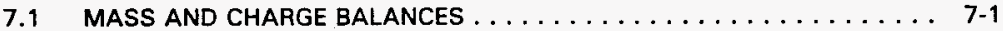

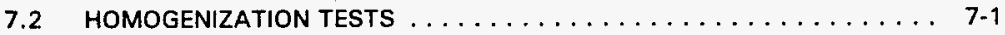

7.3 ANALYTICAL ERROR ESTIMATION $\ldots \ldots \ldots \ldots \ldots \ldots \ldots \ldots \ldots$

8.0 CONCLUSIONS AND RECOMMENDATIONS $\ldots \ldots \ldots \ldots \ldots \ldots \ldots \ldots$

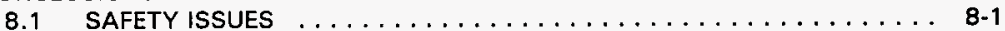

8.2 FURTHER CHARACTERIZATION NEEDS $\ldots \ldots \ldots \ldots \ldots \ldots \ldots$ 8-1

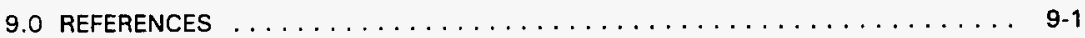

Appendix A. Analytical Results Presentation . . . . . . . . . . . . . . . A

Appendix 8. Statistical Analysis Presentation $\ldots \ldots \ldots \ldots \ldots \ldots \ldots \ldots \ldots$. . . . .

\section{LIST OF FIGURES}

2-1. Double-Shell Tank Configuration $\ldots \ldots \ldots \ldots \ldots \ldots \ldots \ldots \ldots \ldots \ldots$

2-2. Location of the 241 -AP Tank Farm . . . . . . . . . . . . . 2-3

2-3. Waste Volume History of Tank $241-A P-102 \ldots \ldots \ldots \ldots \ldots$

2-4. Tank 241-AP-102 Thermocouple Tree Raw Temperature Plot . . . . . . . 2-13

2-5. Tank 241-AN-106 Thermocouple Tree Raw Temperature Plot . . . . . . . . 2-15

3-1. Double-Shell Tank 241-AP-102 Sample Locations and 222-S Sample Numbers . . 3-2 


\section{LIST OF TABLES}

2-1. Characterization of Tank 241-AN-106 Constituents . . . . . . . . . . 2-7

2-2. Estimated Constituent Concentrations of the DP Waste in Tank 241-AP-102

Prior to Transfer . . . . . . . . . . . . . . . . . . . . . . . 2-9

2-3. Estimated Waste Composition of Tank 241-AP-102 . . . . . . . . . 2-11

3-1. WHC Sample Numbers $\ldots \ldots \ldots \ldots \ldots \ldots \ldots \ldots \ldots \ldots \ldots \ldots$

3-2. PNL Sample Numbers $\ldots \ldots \ldots \ldots \ldots \ldots \ldots \ldots \ldots \ldots \ldots \ldots \ldots$

3-3. 102-AP Samples and Requested Analytes . . . . . . . . . . . . . 3-4

4-1. Analytical Methods . . . . . . . . . . . . . . . . . . 4-4

5-1. Analytical Data Presentation Tables ................... 5-1

5-2. Comparison of Analytical and Historical Estimates of Elemental Constituents in Tank 241-AP-102 ........................ 5-3

5-3. Solubility of Common Sodium Salts $\ldots \ldots \ldots \ldots \ldots \ldots \ldots \ldots \ldots$

5-4. Comparison of Analytical and Historical Estimates of Anionic Constituents in

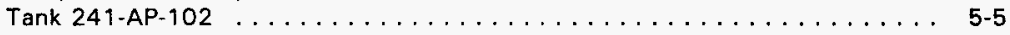

5-5. Comparison of Analytical and Historical Isotopic Resuits for Tank 241-AP-102 . 5-6

5-6. Organic Complexant Concentration Data . . . . . . . . . . . . . . 5-6

5-7. Tank Characterization Report Data for Double-Shell Tank 241-AP-102 . . . . . 5-8

6-1. Tank 241-AP-102 Radionuclide Inventory and Projected Heat Load ... . . . . 6-2

6-2. Applicability of Characterization Information to the Data Needs of the TWRS

Program Elements .......................

7-1a. Mass and Charge Balance ................... 7-2

7-1b. Mass and Charge Balance Totals $\ldots \ldots \ldots \ldots \ldots \ldots \ldots \ldots \ldots$

7-2. Na Data $\ldots \ldots \ldots \ldots \ldots \ldots \ldots \ldots \ldots \ldots \ldots \ldots \ldots \ldots \ldots$

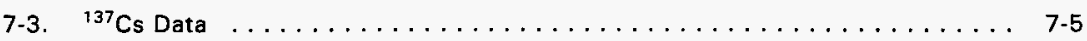

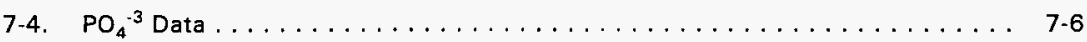

7-5. Measurement Error Estimates $\ldots \ldots \ldots \ldots \ldots \ldots \ldots \ldots \ldots \ldots$

LATA-TCR-9401, Rev. 1 


\section{LIST OF TERMS}

\begin{tabular}{|c|c|}
\hline AA & atomic absorption \\
\hline ANOVA & $\begin{array}{l}\text { alpha energy analysis } \\
\text { analysis of variance }\end{array}$ \\
\hline APC & alpha proportional counting \\
\hline BPC & beta proportional counting \\
\hline CFR & Code of Federal Regulations \\
\hline CLP & Contract Laboratory Program \\
\hline $\mathrm{CP}$ & concentrated phosphate \\
\hline CVAA & cold vapor atomic absorption [waste] \\
\hline DN & dilute non-complexed [waste] \\
\hline DP & dilute phosphate [waste] \\
\hline DNFSB & Defense Nuclear Facilities Safety Board \\
\hline DOE & United States Department of Energy \\
\hline DSC & differential scanning calorimetry \\
\hline DST & Double-Shell Tank \\
\hline EPA & United States Environmental Protection Agency \\
\hline FAA & flame atomic absorption \\
\hline FIC & Food Instrument Corporation \\
\hline GC & gas chromatography \\
\hline GEA & gamma energy analysis \\
\hline GFAA & graphite furnace atomic absorption \\
\hline GHAA & gaseous hydride atomic absorption \\
\hline GTF & Grout Treatment Facility \\
\hline HPLC & high performance liquid chromatography \\
\hline HGDP & Hanford Grout Disposal Program \\
\hline HWVP & Hanford Waste Vitrification Plant \\
\hline IC & Ion Chromatograph \\
\hline ICP & Inductively Coupled Plasma Atomic Emission Spectrometry \\
\hline IDL & instrument detection limit \\
\hline ISE & ion selective electrode \\
\hline LDR & Land Disposal Restrictions \\
\hline LE & low energy \\
\hline LSC & liquid scintillation counting \\
\hline MDL & method detection limit \\
\hline MW & mixed waste \\
\hline PAL & 222-S Process and Analytical Laboratory (Westinghouse Hanford Company) \\
\hline PNL & Pacific Northwest Laboratory \\
\hline PUREX & Plutonium-Uranium Extraction Plant \\
\hline RPD & relative percent difference \\
\hline RSD & relative standard deviation \\
\hline SpG & specific gravity \\
\hline SVOA & semivolatile organic analysis \\
\hline TCLP & toxicity characteristic leach procedure \\
\hline TCR & Tank Characterization Report \\
\hline TGA & thermogravimetric analysis \\
\hline
\end{tabular}


WHC-SD-WM-ER-358 REV O

LIST OF TERMS (continued)

TIC total inorganic carbon

TOC total organic carbon

TWRS Tank Waste Remediation System

VOA volatile organic analysis

WHC Westinghouse Hanford Company 
THISPAGE NTENTONALLY LEFT BLANK 


\subsection{INTRODUCTION}

In April 1993, Double-Shell Tank 241-AP-102 was sampled to determine waste feed characteristics for the Hanford Grout Disposal Program. This Tank Characterization Report presents an overview of that tank sampling and analysis effort, and contains observations regarding waste characteristics, expected bulk inventory, and concentration data for the waste contents based on this latest sampling data and information on the history of the tank. Finally, this report makes recommendations and conclusions regarding tank operational safety issues.

\subsection{PURPOSE}

The purpose of this Tank Characterization Report is to describe and characterize the waste in Double-Shell Tank 241-AP-102 (hereafter Tank 241-AP-102) based on information given from various sources. This report summarizes this available information, and arranges it in a useful format for making management and technical decisions concerning this particular waste tank. In addition, conclusions and recommendations based on safety issues and further characterization needs are given. This report presents a comprehensive overview of the material in Tank 241-AP-102. Specific objectives reached by the sampling and characterization of the waste in Tank 241-AP-102 are:

- Contribute toward the fulfillment of the Hanford Federal Facility Agreement and Consent Order (Tri-Party Agreement) Milestone M-44-05 concerning the characterization of Hanford Site high-level radioactive waste tanks (Ecology, EPA and DOE, 1993).

- Complete safety screening of the contents of Tank 241-AP-102 to meet the characterization requirements of the Defense Nuclear Facilities Safety Board (DNFSB) Recommendation 93-05 (Conway, 1993).

- Provide tank waste char acterization information to the Tank Waste Remediation Systern (TWRS) Program Elements in accordance with the TWRS Tank Waste Characterization Plan, WHC-SD-WM-PLN-047, Rev. O (Bell, 1993).

\subsection{SCOPE}

This report presents a broad background of historical information that was available prior to the latest sampling activity. The result of this review is the detailed estimation of the contents of Tank 241-AP-102 based on historical process information and detailed transaction records. Next, the results of the sampling and analysis effort are summarized, and interpreted both qualitatively and quantitatively. The information obtained from historical sources is then compared with the actual waste measurements to arrive at final waste inventory and concentration estimates. Finally, specific safety issues and program element needs are addressed based on the results of the waste characterization. 


\subsection{ASSUMPTIONS}

The concentration and inventory estimates derived for this report are considered by the authors and by the Westinghouse Hanford Company Characterization Program to be the most accurate, defensible, technically valid, and contemporary data concerning Double-Shell Tank 241-AP-102. This Tank Characterization Report incorporates all available previous sampling, characterization, and transfer data concerning Tank 241-AP-102. In addition, estimates of the current tank contents based on process knowledge and waste transaction records provide important cross-checks and corroboration to the inventory estimates derived from recent analytical data. Based on the statistical determination that the tank waste is homogenous, and given that the analytical data is valid and defensible, this report is therefore the definitive characterization of the contents of Tank 241-AP-102.

The term "analytical results" is used in this report to denote sample results from the most recent sampling event, the characterization of Tank 241-AP-102 waste for the Hanford Grout Disposal Program. Characterization data from these samples are used for the analytical section of this report, Section 5.0. The historical characterization of this tank, Section 2.0, is based on the available "historical results" prior to the 1993 sampling. 


\subsection{HISTORICAL TANK INFORMATION}

The purpose of this section is to describe Tank 241-AP-102 based on historical tank information, and to use this information to predict the constituents of the tank and their concentrations. This section is divided into six parts. A brief description and historical background of the tank comprise the first two parts, followed by the current tank status, a summary of the process sources that contributed to the tank waste, and an estimation of the contents of Tank 241-AP-102 based on historical information. The final part details the surveillance data taken on the tank.

\subsection{TANK HISTORY}

Double-Shell Tank 241-AP-102 is a tank-in-tank design consisting of a heat-treated primary steel liner, inside a second steel liner. The tank has a design capacity for storing 1.16 million gallons of waste; however, safety considerations require a maximum operating capacity of 1.14 million gallons. Instruments access the tank through risers and monitor the pressure, temperature, liquid level and other bulk tank characteristics (Bell, 1993). A detailed diagram of a double-shell tank is presented in Figure 2-1.

Tank 241-AP-102 was constructed and went into service in 1986 as the feed tank for the Grout Treatment Facility (GTF), and is located in Hanford's 200 East Area between the PUREX Plant and the GTF and Disposal Site. Figure 2-2 contains a map showing the location of the 241-AP Tank Farm.

241-AP-102 is used to collect and store solutions from several sources. These sources include the Plutonium-Uranium Extraction Plant (PUREX) Ammonia Scrubber supernate from Tank 241-AN-106, which contained decontamination waste from Hanford's 100 Area NReactor, Tank 241-AP-104, waste consisting of dilute phosphate and dilute non-complexed waste from the $100 \mathrm{~N}$ area, and miscellaneous flush water.

During Grout Campaign 101, in which grout was blended and poured into Vault 101 , all of the contents of Tank 241-AP-102 were transferred to grout, except for a residual "heel" of dilute phosphate (DP) waste which originated in Tank 241-AP-104. The leachate and excess drainable liquids resulting from the grout curing process were returned back to Tank 241-AP-102 and combined with this heel. PUREX Ammonia Scrubber Feed (PASF), consisting of neutralizing agents, were then added to Tank 241-AP-102 to ensure waste compatibility by raising the $\mathrm{pH}$ of the waste. The majority of the tank's present contents were then received in several transfers of concentrated phosphate (CP) solution from Tank 241-AN-106 in the third and fourth quarters of 1992.

\subsection{TANK STATUS}

Tank 241-AP-102 currently contains $1,104,000$ gallons of concentrated phosphate (CP) and dilute phosphate (DP) waste. The waste is entirely composed of liquid with no sludge or salt cake (Hanlon, 1994). The tank is at $97 \%$ capacity (volume) with the waste occupying approximately the bottom 401 inches of the tank. Tank surveillance thermocouple data indicate the tank temperature to be $82^{\circ} \mathrm{F}$ as of $12 / 93$. The tank is not currently 


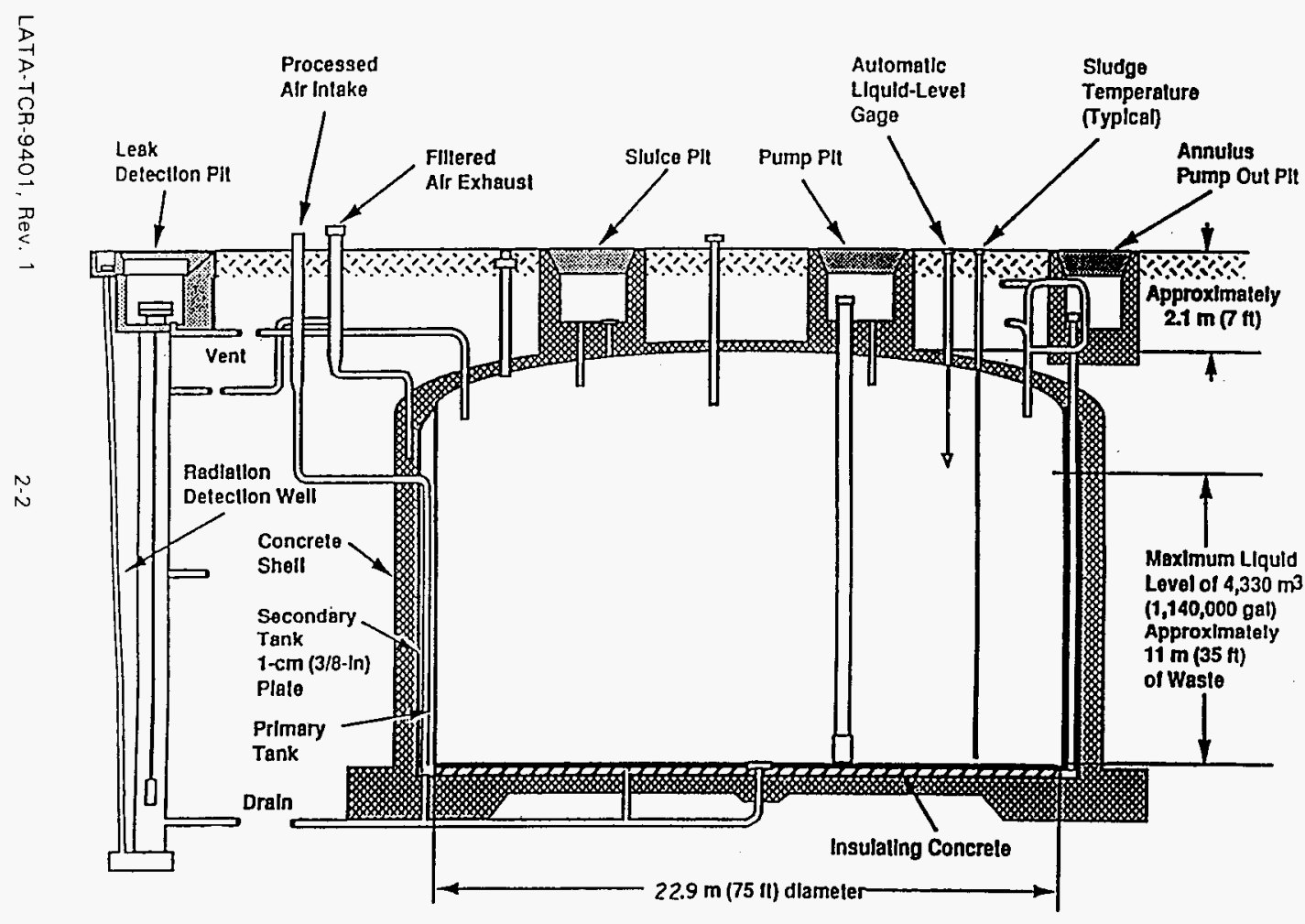

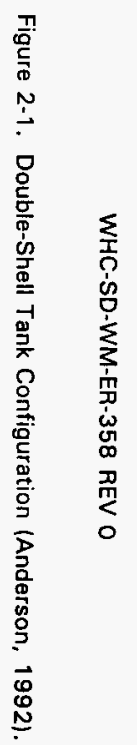


Figure 2-2. Location of the 241-AP Tank Farm (Husa et al., 1993)

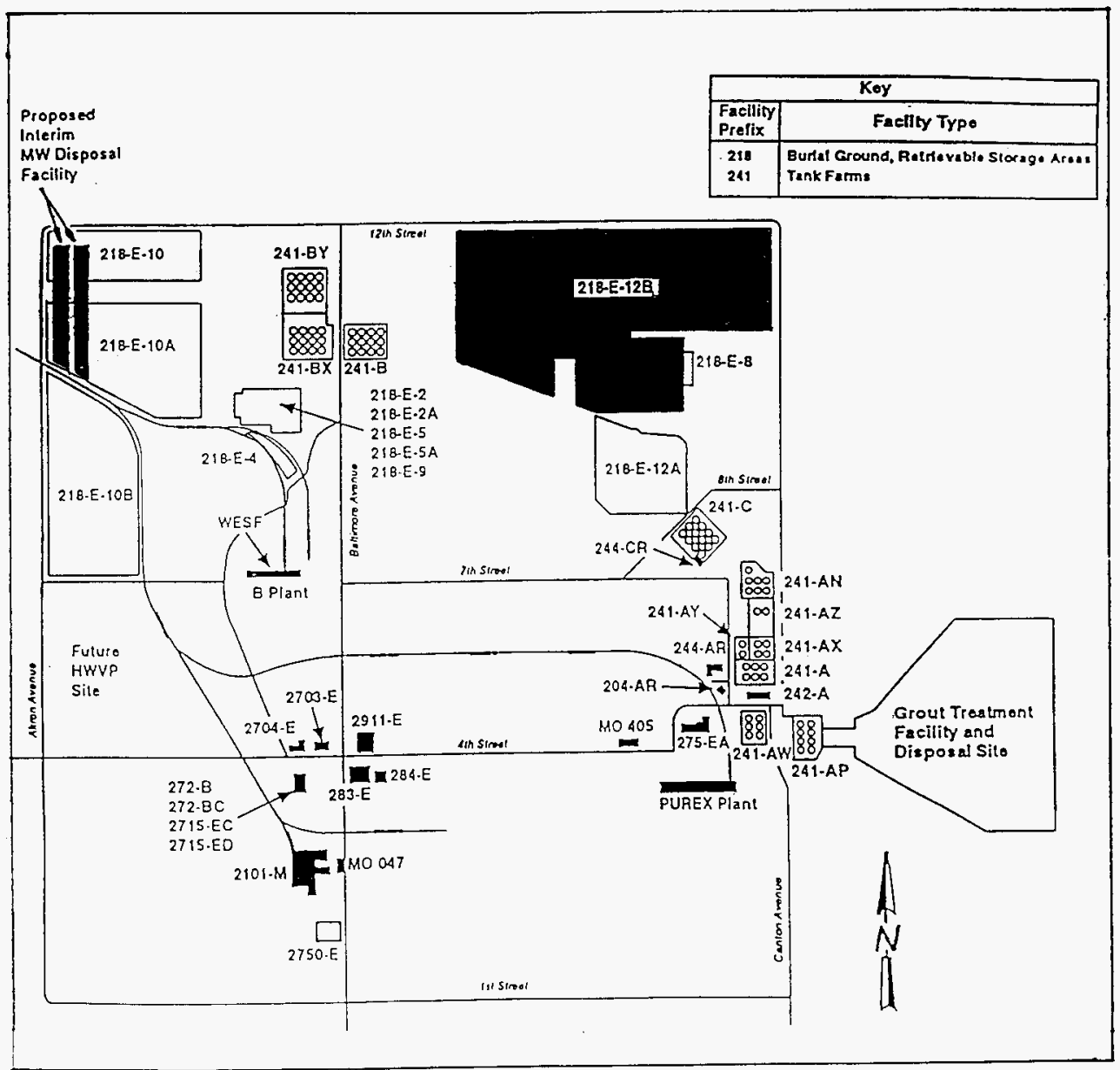


designated as a watch list tank and the tank integrity is classified as sound. There are no Unreviewed Safety Questions (USOs) associated with Tank 24 1-AP-102 at this time. Tank 241-AP-102 remains in active service for waste management operations. The tank contains a mixing pump which stopped working prior to sampling.

\subsection{PROCESS KNOWLEDGE}

Figure 2-3 depicts the fill history of Tank 241-AP-102 for the time period from 1986 , when the tank became operational, to the first quarter 1993, the time at which the most recent samples were collected. The waste volume presented in this figure corresponds to the data contained in the Waste Volume Projection Database (Koreski, 1994). The entries contained in this database are broken down by waste type and by quarter. As seen in Figure 2-3, only two general types of waste were added to Tank 241-AP-102: concentrated phosphate waste from Tank 241-AN-106; and dilute phosphate waste from Tank 241-AP104, the PUREX Ammonia Scrubber, Grout product leachate returns, and flush water from miscellaneous sources.

A detailed description of the events that contributed to waste being added to or transferred from this tank, and an estimated characterization of the waste types, follows. (Several sources were used to write this section; however, the actual volume measurements are taken from the Waste Volume Projection Database [Koreski, 1994] unless noted otherwise.) Volume measurement discrepancies that were detected between reference sources have also been noted in this section.

Waste from Tank 241-AP.104, consisting of dilute phosphate waste from the $100 \mathrm{~N}$ Area, and flush water from miscellaneous sources were added to Tank 241-AP-102 between 1986 and 1988 . Grout Campaign 101 began in the third quarter of 1988 and continued through the third quarter of 1989 . This campaign consisted of the cementitious disposal of phosphate/sulfate waste from the $100 \mathrm{~N}$-Reactor decontamination activities. During Campaign 101, nearly all of the contents from Tank 241-AP-102 were retrieved and grouted. At the completion of this campaign, approximately 72,000 gallons of the original dilute phosphate feed material remained in Tank $241-A P-102$ as a residual "heel" of liquid (Hendrickson et al., 1993).

After the grout product was cured, approximately 55,000 gallons of excess liquid and leachate from disposal Vault 101 were returned to Tank 241-AP-102 in July 1989. Uncertainties in waste $\mathrm{pH}$ compatibility to the tank required that two small transfers of sodium nitrite/sodium hydroxide solution from the PUREX Ammonia Scrubber be conducted during September and October 1989 to protect the steel liner of Tank 241-AP-102. According to Hendrickson et al., (1993) this transfer involved approximately 7,150 gallons. However, only 5,000 gallons are noted by Koreski (1994) as being transferred from the PUREX Ammonia Scrubber to Tank 241-AP-102. Leachate which had developed over a longer period from Vault 101 was subsequently transferred into Tank 241-AP-102 in two small transfers totalling 2,550 gallons (Hendrickson et al., 1993). The tank activity between the first quarter of 1990 and third quarter 1992 consisted of numerous gains and losses of no more than 3,000 gallons each that were attributed to unknown sources. These fluctuations may be attributed to several causes; possibly evaporation, moisture gain from the air in the tank, flushing the tank with water, or even measurement inconsistencies, since an inch on the measuring tape is equivalent to approximately 2,750 gallons of waste.

LATA-TCR-9401, Rev. 1 
WHC-SD-WM-ER-358 REV 0

Figure 2-3. Waste Volume History of Tank 241-AP-102.

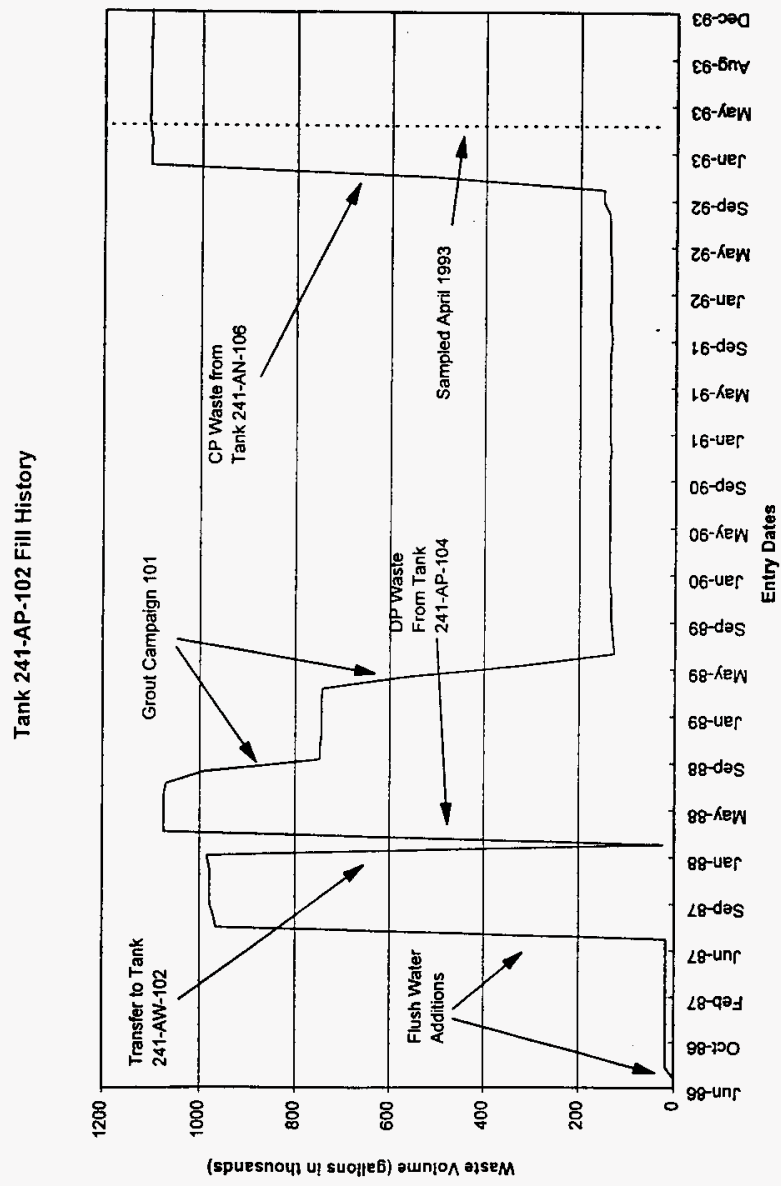


Tank 241-AP-102 contained approximately 137,000 gallons of dilute phosphate (DP) waste in the third quarter 1992, prior to the addition of the majority of the tank's current waste from Tank 241-AN-106. The resident DP waste was composed of residual phosphate/sulfate waste, leachate returns from Vault 101, and chemical additions from PUREX to increase the alkalinity of the leachates; this waste comprises 12 percent of the current tank waste volume. In November and December of 1992, the tank received approximately 88 percent of its final volume with the transfer of supernatant liquor contents from Tank 241-AN-106, consisting primarily of concentrated phosphate (CP) waste. The CP waste was partially evaporated phosphate waste resulting from the decontamination of Hanford's N-Reactor. The volume for this transfer was estimated at $\mathbf{9 7 2 , 0 0 0}$ gallons by Koreski (1994) and by Hendrickson et al., (1993); however, according to Welsh (1993) this volume equaled 973,500 gallons. The discrepancy between the sources is not significant in this case.

Following the transfer of CP waste from Tank 241-AN-106, the tank's fill activity was minimal. The transfers that took place between first quarter 1993 and fourth quarter 1993 consisted of several smail gains and losses, each of no more than 4,000 gallons that were attributed to unknown sources. The final volume for the tank was reported at $1,104,000$ gallons at the end of fourth quarter 1993: 970,000 gallons of CP waste and 134,000 gallons of DP waste.

\subsection{HISTORICAL ESTIMATION OF THE CONTENTS OF TANK 241-AP-102}

By reviewing the historical characterization data for Tank 241-AP-102, a preliminary estimate of its present waste constituents can be made and used as a baseline for comparison. This estimate then appears as the Historic Tank Content Estimated in Table 5-4. Following are descriptions of the tables that were created using these historical sources to generate concentration and inventory estimates.

Table 2-1 presents the estimated waste composition of Tank 241-AN-106 when it was fully mixed prior to its transfer to Tank 241-AP-102 (Hendrickson et al., 1993). As explained in Section 2.4, 88 percent of the waste currently in Tank 241-AP-102 resulted from several transfers of concentrated phosphate (CP) waste from Tank 241-AN-106. Results are reported to three significant digits; those reported with a less than $(<)$ sign were below the detection limit of the analytical procedure, meaning they may be present at any concentration less than this value or not present at all.

Table 2-2 presents the estimated waste composition of Tank 241-AP-102 prior to the transfer of Tank 241-AN-106 (hendrickson et al., 1993). Twelve percent of the tank's current contents is comprised of dilute phosphsate (DP) waste that occupied the tank prior to the Tank 241-AN-106 transfer of CP waste in the fourth quarter of 1992. The most recent historical sample results from Tank 241-AP-102 were taken in April 1988 prior to Grout Campaign 101. The analytical results from these samples have been used as a basis for the characterization of the tank's contents prior to the grout transfer. It should be noted that these results can only provide an estimated characterization of the waste in the tank prior to the transfer, since numerous transfers involving large percentages of the tank's contents took place between the sampling in 1988 and the addition of the CP waste in 1992. However, the 1988 samples were the most recent results, and were therefore considered the best available source for characterization.

LATA-TCR-9401, Rev. 1 
WHC-SD-WM-ER-358 REV O

Table 2-1. Characterization of Tank 241-AN-106 Constituents (Hendrickson et al., 1993). (2 pages)

\begin{tabular}{|c|c|}
\hline Analyte & $\begin{array}{l}\text { Analytical Data Reault } \\
\text { Composite Mean }\end{array}$ \\
\hline Metais & $(\mu g / L)$ \\
\hline Al & $9.28 E+06$ \\
\hline As & 72 \\
\hline $\mathrm{Ba}$ & $<11,100$ \\
\hline $\mathrm{Bi}$ & $<145,000$ \\
\hline $\mathrm{Cd}$ & $<49,600$ \\
\hline $\mathrm{Ca}$ & 90,200 \\
\hline $\mathrm{Cr}$ & 564,000 \\
\hline $\mathrm{Cu}$ & $<3,750$ \\
\hline $\mathrm{Fe}$ & $<6,900$ \\
\hline $\mathrm{Pb}$ & $<460,000$ \\
\hline $\mathrm{Mg}$ & 2,780 \\
\hline Mn & $<55,700$ \\
\hline $\mathrm{Hg}$ & $<50$ \\
\hline Mo & $<66,600$ \\
\hline $\mathrm{Np}$ & $<3,000$ \\
\hline$P$ & $6.11 E+06$ \\
\hline $\mathrm{K}$ & $1.08 E+06$ \\
\hline $\mathrm{Se}$ & 134 \\
\hline $\mathrm{Ag}$ & $<3,630$ \\
\hline $\mathrm{Na}$ & $9.03 E+07$ \\
\hline $\mathrm{Ti}$ & $<3,510$ \\
\hline$u$ & 4,000 \\
\hline $\mathrm{Zn}$ & $<9,440$ \\
\hline $\mathrm{Zr}$ & $<27,800$ \\
\hline lons & $(\mu \mathrm{g} / \mathrm{L})$ \\
\hline $\mathrm{NH}_{3}$ & 123,000 \\
\hline $\mathrm{CO}_{3}{ }^{2-}$ & $1.962 \mathrm{E}+07$ \\
\hline $\mathrm{Cl}^{-}$ & $2.46 \mathrm{E}+06$ \\
\hline
\end{tabular}


Table 2-1. Characterization of Tank 241-AN-106 Constituents (Hendrickson et al., 1993). (2 pages)

\begin{tabular}{|c|c|}
\hline Analyte & $\begin{array}{l}\text { Analytical Data Result } \\
\text { Composito Mean }\end{array}$ \\
\hline Ions (continued) & $(\mu g / L)$ \\
\hline $\mathrm{CN}^{-}$ & 6,000 \\
\hline $\mathrm{OH}^{-}$ & $8.06 E+06$ \\
\hline$F^{*}$ & $<61,600$ \\
\hline $\mathrm{NO}_{2}^{-}$ & $2.96 E+07$ \\
\hline $\mathrm{NO}_{3}{ }^{-}$ & $6.85 E+07$ \\
\hline $\mathrm{PO}_{4}{ }^{3 \cdot}$ & $1.84 E+07$ \\
\hline $\mathrm{SO}_{4}{ }^{2}$ & $2.15 E+06$ \\
\hline Radionuclides & $(\mu \mathrm{Ci} / \mathrm{L})$ \\
\hline${ }^{241} \mathrm{Am}$ & 0.606 \\
\hline${ }^{14} \mathrm{C}$ & 0.335 \\
\hline${ }^{134} \mathrm{Cs}$ & $<24$ \\
\hline${ }^{137} \mathrm{Cs}$ & 205,000 \\
\hline${ }^{60} \mathrm{Co}$ & $<9$ \\
\hline${ }^{243} \mathrm{Cm}$ & 0.0470 \\
\hline 129$\}$ & $<0.0750$ \\
\hline${ }^{94} \mathrm{Nb}$ & $<23$ \\
\hline${ }^{238} \mathrm{Pu}$ & 0.0200 \\
\hline${ }^{239 / 240} \mathrm{Pu}$ & 0.0378 \\
\hline${ }^{106} \mathrm{Ru} / \mathrm{Rh}$ & $<1,390$ \\
\hline${ }^{79} \mathrm{Se}$ & 0.240 \\
\hline${ }^{90} \mathrm{Sr}$ & 2,230 \\
\hline${ }^{99} \mathrm{Tc}$ & 69 \\
\hline${ }^{3} \mathrm{H}$ & 3 \\
\hline Physical Properties & - \\
\hline Water & $77.6 \%$ \\
\hline Density & $1.23 \mathrm{~g} / \mathrm{cm}^{3}$ \\
\hline TOC & $3.26 \mathrm{E}+06 \mu \mathrm{g} / \mathrm{L}$ \\
\hline
\end{tabular}


Table 2-2. Estimated Constituent Concentrations of the DP Waste in Tank 241-AP-102 Prior to Transfer (Hendrickson et al., 1993).

\begin{tabular}{|c|c|}
\hline Analyte & Analytical Date Result \\
\hline Metals ${ }^{(1)}$ & $(\mu \mathrm{g} / \mathrm{L})$ \\
\hline B & 5,000 \\
\hline $\mathrm{Ca}$ & 5,300 \\
\hline $\mathrm{Cr}$ & 1,700 \\
\hline $\mathrm{Fe}$ & 1,900 \\
\hline $\mathrm{Mg}$ & 1,500 \\
\hline $\mathbf{P}$ & $5.59 E+06$ \\
\hline $\mathrm{Si}$ & 4,000 \\
\hline $\mathrm{Na}$ & $1.25 E+07$ \\
\hline Ions & $(\mu \mathrm{g} / \mathrm{L})$ \\
\hline $\mathrm{CO}_{3}{ }^{2-}$ & $2.01 E+06$ \\
\hline $\mathrm{Cl}^{-}$ & 15,500 \\
\hline$F^{-}$ & 12,600 \\
\hline $\mathrm{NO}_{2}^{-}$ & 810 \\
\hline $\mathrm{NO}_{3}^{-}$ & 123,000 \\
\hline $\mathrm{PO}_{4}{ }^{3-}$ & $1.48 \mathrm{E}+07$ \\
\hline $\mathrm{SO}_{4}{ }^{2-}$ & $1.42 E+06$ \\
\hline Radionuclides $^{(2)}$ & $(\mu \mathrm{Ci} / \mathrm{L})$ \\
\hline${ }^{241} \mathrm{Am}$ & 7.44 E-03 \\
\hline${ }^{137} \mathrm{Cs}$ & 0.489 \\
\hline${ }^{60} \mathrm{Co}$ & 6.35 \\
\hline${ }^{242} \mathrm{Cm}$ & $9.34 \mathrm{E}-03$ \\
\hline${ }^{244} \mathrm{Cm}$ & 0.0366 \\
\hline${ }^{89 / 90} \mathrm{Sr}$ & 0.0341 \\
\hline Total $a$ & 0.0333 \\
\hline
\end{tabular}

(1) Values reported for metals and anions based on single sample result.

(2) Values reported for radionuclides based on highest reported activity of four sample results. 
Table 2-3 presents the final estimated waste composition of Tank 241-AP-102 based on historical sample results. The final historical result has been derived for each constituent by taking a weighted sum of the two sets of characterization data. Specifically, the historical estimate is derived by adding $88 \%$ of the value in Table $2-1$ and $12 \%$ of the value in Table 2-2. Several assumptions were necessary in deriving these final values. First, in the case where an analyte was present at a value less than the instrument detection limit, the detection limit value was maintained as the tank estimate. This provides a conservative estimate which does not attempt to alter the predetermined lower limit of quantitation. Second, the number of analytes reported in Table $2-2$ is considerably smaller than those reported in Table 2-1, because only a limited number of analyses were requested in the characterization of Tank 241-AP-102. Since these constituents were not analyzed, they were assumed to be zero (even though they may be present), and $88 \%$ of the result in Table 2-1 was taken as the historical estimate of the concentration of that particular analyte in the tank. Finally, an exception to the above method applied to the density and percent water values. These values were only available for the characterization of Tank 241-AN-106 and were assumed to be characteristic of the waste currently in the tank.

\subsection{SURVEILLANCE DATA}

\subsubsection{Surface Level Readings}

Tank 241-AP-102 is equipped with a liquid level gauge manufactured by the Food Instrument Corporation ( $\mathrm{FIC}$ ) which can be monitored either automatically or manually. The FIC indicator uses a conductivity probe to detect the level of the tank's contents and, in the automatic mode, is electrically connected to a computer for data transmission via the Computer Automated Surveillance System. Tank 241-AP-102 is also equipped with a manual tape from which readings are taken when the FIC indicator is out of service. The most recent liquid level measurement available was 401 inches on March 4, 1994 based on manual tape readings (Rios, 1994). The FIC indicator has been out of service since January 1993 (Hanlon, 1994).

\subsubsection{Internal Tank Temperatures}

Tank 241-AP-102, as well as all other double-shell tanks, is equipped with thermocouples (thermoelectric temperature measuring devices) in the tank interior, the annular space and in the concrete outer shell. A thermocouple tree with eighteen thermocouples assembled in a pipe and inserted into a waste tank, is used to monitor the waste temperatures at various levels in the primary tank, usually every two feet. Temperature readings for Tank 241-AP-102 have been automatically and manually recorded since July 1989 by surveillance analysis computer systems. The maximum waste temperatures from the weekly manual readings has been plotted over time and are presented in Figure 2-4 (Rios, 1994). Maximum temperatures are typically reported from thermocouples located in the vertical center of the tank, and a slight negative temperature gradient exists with waste depths above and below the tank center. 
Table 2-3. Estimated Waste Composition of Tank 241-AP-102. (2 pages)

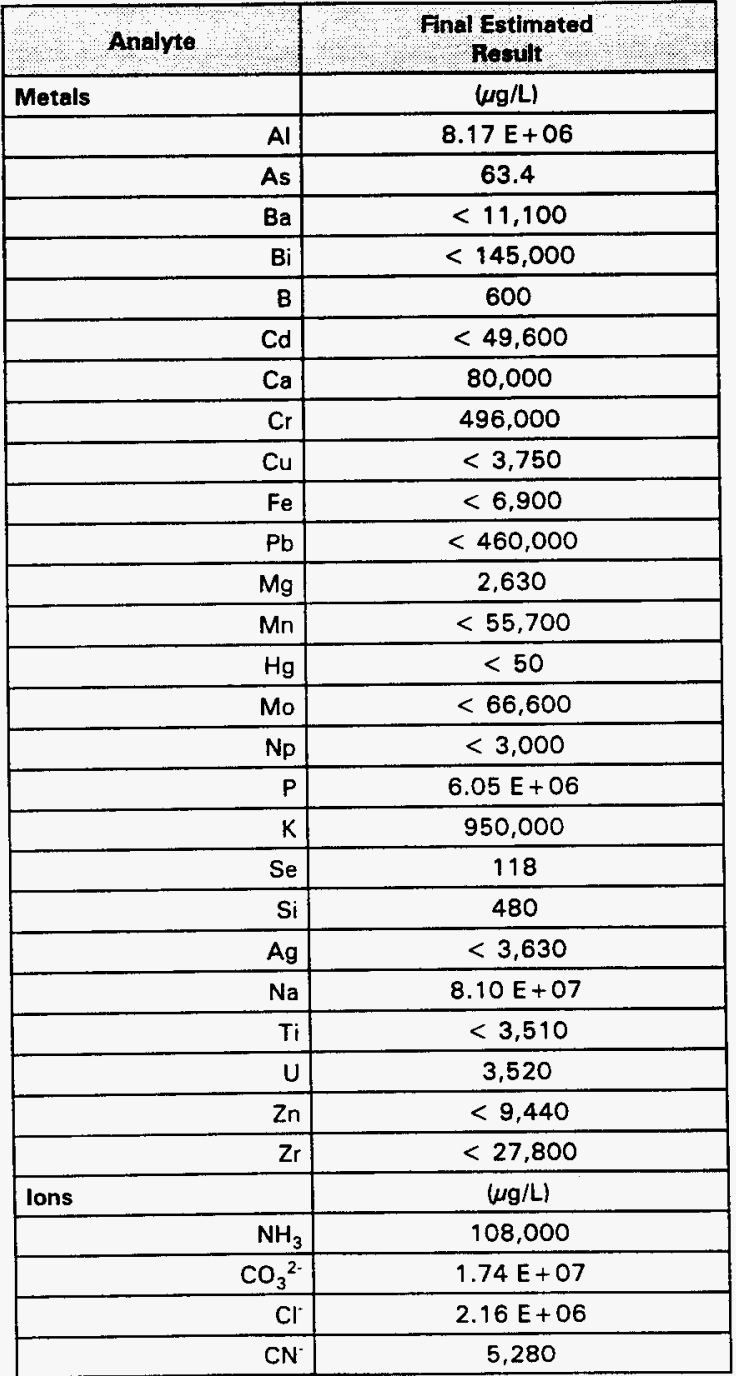


Table 2-3. Estimated Waste Composition of Tank 241-AP-102. (2 pages)

\begin{tabular}{|c|c|}
\hline Analyte & $\begin{array}{l}\text { Final Estimated } \\
\text { Result }\end{array}$ \\
\hline lons (continued) & $(\mu \mathrm{g} / \mathrm{L})$ \\
\hline $\mathrm{OH}^{-}$ & $7.09 E+06$ \\
\hline$F^{-}$ & $<61,600$ \\
\hline $\mathrm{NO}_{2}^{-}$ & $2.6 E+07$ \\
\hline $\mathrm{NO}_{3}^{-}$ & $6.03 \mathrm{E}+07$ \\
\hline $\mathrm{PO}_{4}{ }^{3-}$ & $1.8 E+07$ \\
\hline $\mathrm{SO}_{4}{ }^{2-}$ & $2.06 \mathrm{E}+06$ \\
\hline Radionuclides & $(\mu \mathrm{Ci} / \mathrm{L})$ \\
\hline${ }^{241} \mathrm{Am}$ & 0.534 \\
\hline${ }^{14} \mathrm{C}$ & 0.295 \\
\hline${ }^{134} \mathrm{Cs}$ & $<24$ \\
\hline${ }^{137} \mathrm{Cs}$ & 180,000 \\
\hline${ }^{60} \mathrm{Co}$ & $<9$ \\
\hline${ }^{242} \mathrm{Cm}$ & $1.12 \mathrm{E}-03$ \\
\hline${ }^{243} \mathrm{Cm}$ & 0.0414 \\
\hline${ }^{244} \mathrm{Cm}$ & $4.39 \mathrm{E}-03$ \\
\hline $129 \mathrm{I}$ & $<0.0750$ \\
\hline${ }^{94} \mathrm{Nb}$ & $<23$ \\
\hline${ }^{238} \mathrm{Pu}$ & 0.0176 \\
\hline $239 / 240 \mathrm{Pu}$ & 0.0333 \\
\hline${ }^{106} \mathrm{Ru} / \mathrm{Rh}$ & $<1390$ \\
\hline${ }^{79} \mathrm{Se}$ & 0.211 \\
\hline${ }^{89 / 90} \mathrm{Sr}$ & 1,960 \\
\hline$T c^{99}$ & 60.7 \\
\hline Total $a$ & $4.00 \mathrm{E}-03$ \\
\hline${ }^{3} \mathrm{H}$ & 2.6 \\
\hline \multicolumn{2}{|l|}{ Physical Properties } \\
\hline Water $^{(1)}$ & $77.6 \%$ \\
\hline $\mathrm{pH}$ & 13.62 \\
\hline Density $^{(1)}$ & $1.23 \mathrm{~g} / \mathrm{cm}^{3}$ \\
\hline TOC & $2.87 \mathrm{E}+06 \mu \mathrm{g} / \mathrm{L}$ \\
\hline
\end{tabular}

(1) These values were not multiplied by $88 \%$, rather this value was assumed to be constant for the entire contents of the tank. 
WHC-SD-WM-ER-358 REV O

Figure 2-4. Tank 241-AP-102 Thermocouple Tree Raw Temperature Plot.

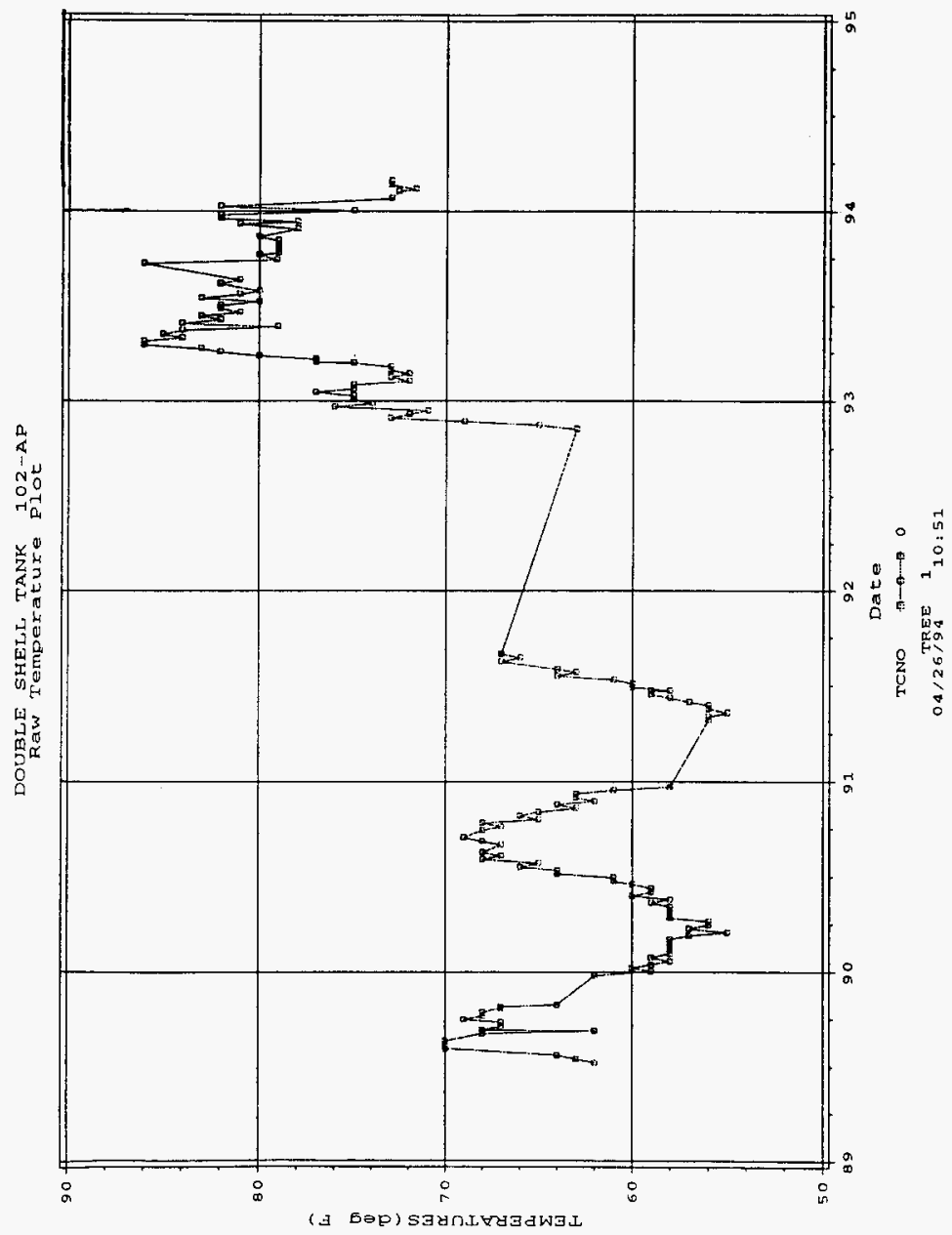


With the exception of two periods where the thermocouple equipment was out of service, the internal temperature of Tank 241-AP-102 has been monitored approximately weekly. From the time the first thermocouple reading was taken to the time the concentrated phosphate (CP) waste transfer from Tank 241-AN-106 took place, the temperatures ranged from a high of $70^{\circ} \mathrm{F}$ in the summer months to a low of $55^{\circ} \mathrm{F}$ in the winter months. For unknown reasons, there were no readings available for approximately a one year time period between September 1991 to October 1992. In the fourth quarter of 1992, the temperature of the waste increased significantly, reaching a high of $86^{\circ} \mathrm{F}$ in the summer months and a low of $78^{\circ} \mathrm{F}$ in the winter months. This temperature increase was caused by the transfer of 616,000 gallons of CP waste from Tank 241-AN-106, which was substantially higher in radionuclide content than the previous waste contained in Tank 241-AP-102 (see Section 5.2). The temperature of the waste in Tank 241-AN-106 at the time of the transfer was $80^{\circ} \mathrm{F}$. This can be seen in Figure 2-5, which plots Tank 241-AN-106's maximum waste temperature readings. Also of note in Figure $2-5$ is the corresponding reduction in the maximum temperature of Tank 241-AN-106's waste after the transfer into Tank 241-AP-102, a result of losing almost $97 \%$ of its waste volume. The heat load in Tank 241-AP-102 due to its radionuclide inventory is presented in Section 6.2. Also, a temperature increase near the end of the second quarter of 1993 can be attributed to operation of the tank mixing pumps prior to the 1993 sampling event. The last available temperature reading for Tank 241-AP-102 was $82^{\circ} \mathrm{F}$, taken at the end of December, 1993. Since the addition of the 241AN-106 waste, Tank 241-AP-102 is assumed to have reached homogeneous thermal stability at a higher temperature range. 
Figure 2-5. Tank 241-AN-106 Thermocouple Tree Raw Temperature Plot.

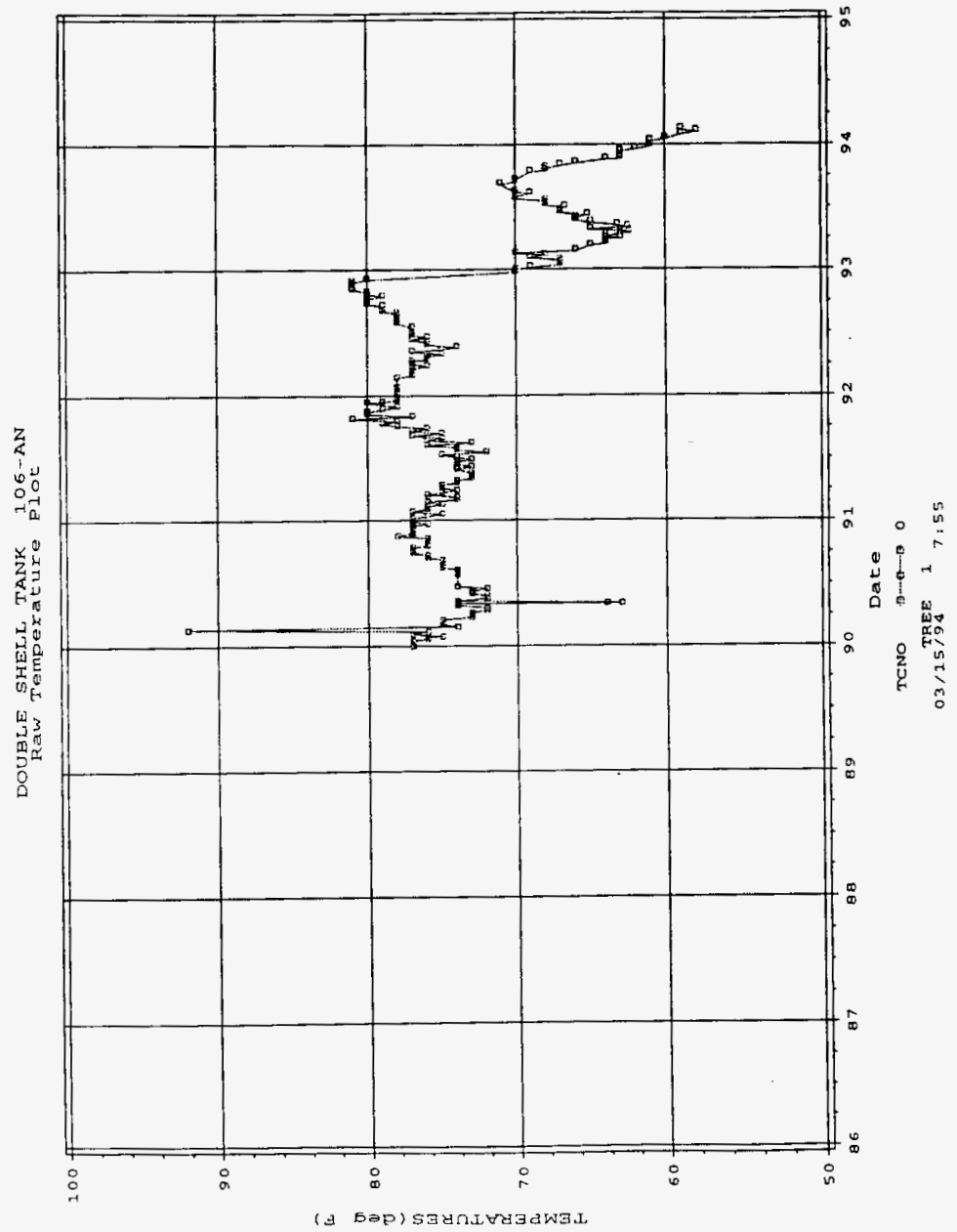


THSPAGE NTENTONALV LET BLANK 


\subsection{TANK SAMPLING OVERVIEW}

The sampling program was designed to accomplish two objectives. First, it was designed to characterize Tank 241-AP-102 for permitting purposes and to show that the waste was suitable feed for the grout process. Second, it was designed to demonstrate that the action of the in-tank mixer pump was sufficient to homogenize the tank wastes.

\subsection{DESCRIPTION OF SAMPLING EVENT}

Tank 241-AP-102 was sampled on 04/28, 04/29, and 04/30/1993. To ensure sampling homogeneity, the tank was mixed for 53 days before sampling occurred. The absence of a sludge layer was confirmed by the sound of a weighted tape hitting the metal bottom of the tank (Welsh, 1993).

Samples were obtained by using the "bottle-on-a-string" method. Each glass sample bottle collected approximately $125 \mathrm{~mL}$ of liquid. To be consistent with safety procedures that help to limit personnel exposure to hazardous ionizing radiation, no attempt was made to ensure completely full bottles; as a result, there was the potential for headspace in all sample bottles.

To demonstrate homogeneity required that samples representative of the entire volume be obtained (Duchsherer, 1993). Therefore, samples were collected from 3 fixed, vertical 4 inch risers (Riser Type 1), located 120 degrees apart at a radius of 20 feet from the tank center. Also, the samples' locations varied in depth to cover the entire vertical range of the contents in the tank (Figure 3-1). Because of the shielding requirements for the shipping containers, refrigeration of the sample was not possible. In addition, preservatives were not used in the sample bottles because the waste was not expected to contain any biological activity that might influence the results of an unpreserved sample.

\subsection{SAMPLE NUMBERS AND REQUESTED ANALYTES}

Eighteen samples (five per riser, plus three duplicates) were submitted to the Westinghouse Hanford Company 222-S Process and Analytical Laboratory for analysis. Table 3-1 presents the laboratory numbers for these samples along with sampling location within the Tank. These sample results were used to characterize the inorganic and radiochemical properties of the tank. In addition, two samples per riser plus one duplicate were shipped to the Pacific Northwest Laboratory for organic analyses. Table 3-2 displays the numbers assigned to the samples by the laboratory along with the sampling location in the tank. A list of the analytes requested for evaluation from each laboratory is presented in Table 3-3. 
Figure 3-1. Double-Shell Tank 241-AP-102 Sample Locations and 222-S Sample Numbers.

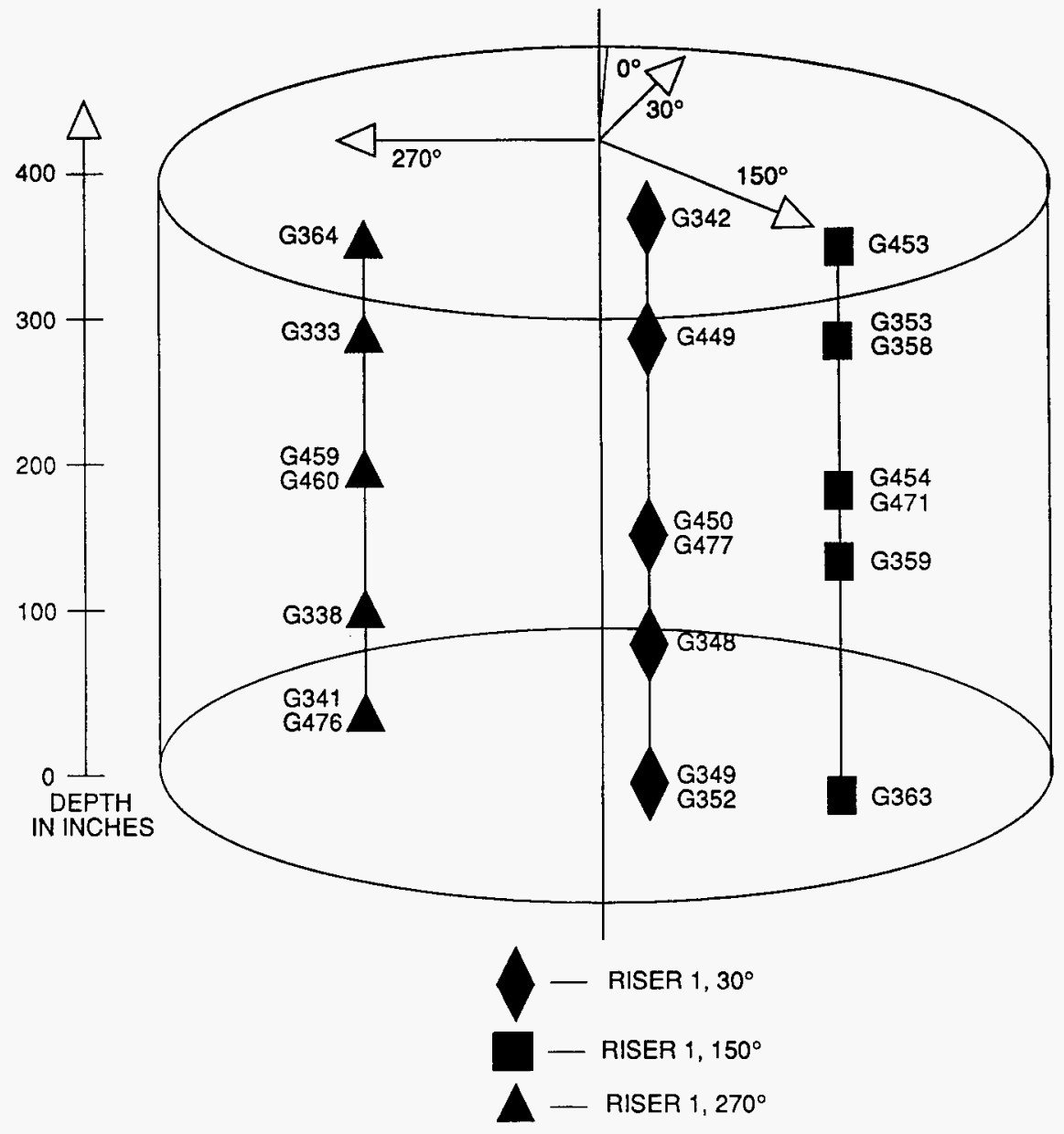


WHC-SD-WM-ER-358 REV 0

Table 3-1. WHC Sample Numbers (Welsh, 1993).

\begin{tabular}{|c|c|c|c|}
\hline $\begin{array}{l}\text { Riser, } \\
\text { Angle }\end{array}$ & $\begin{array}{l}\text { Depth linches from } \\
\text { the bottom of the } \\
\text { tank) }\end{array}$ & $\begin{array}{l}\text { Tank Farm } \\
\text { Sample } \\
\text { Number }\end{array}$ & $\begin{array}{l}\text { Laboratory } \\
\text { Sample Number }\end{array}$ \\
\hline $\begin{array}{l}1 \text { (NE), } 30^{\circ} \\
1 \text { (NE), } 30^{\circ} \\
1 \text { (NE), } 30^{\circ} \\
1 \text { (NE), } 30^{\circ} \\
1 \text { (NE), } 30^{\circ} \\
1 \text { (NE), } 30^{\circ}\end{array}$ & $\begin{array}{l}360 \text { Inches } \\
271 \text { Inches } \\
182 \text { Inches } \\
125 \text { Inches } \\
34 \text { Inches } \\
34 \text { Inches }\end{array}$ & $\begin{array}{l}\text { G299 } \\
\text { G301 } \\
\text { G302 } \\
\text { G303 } \\
\text { G305 } \\
\text { G306 } \\
\end{array}$ & $\begin{array}{l}\text { G342, G509* } \\
\text { G449, G523* } \\
\text { G450, G477* } \\
\text { G348, G510* } \\
\text { G239, G511* } \\
\text { G352, G521* }\end{array}$ \\
\hline $\begin{array}{l}1 \text { (SE), } 150^{\circ} \\
1(S E), 150^{\circ} \\
1(S E), 150^{\circ} \\
1(S E), 150^{\circ} \\
1(S E), 150^{\circ} \\
1(S E), 150^{\circ}\end{array}$ & $\begin{array}{c}391 \text { Inches } \\
334 \text { Inches } \\
334 \text { Inches } \\
208 \text { Inches } \\
162 \text { Inches } \\
18 \text { Inches }\end{array}$ & $\begin{array}{l}\text { G307 } \\
\text { G308 } \\
\text { G309 } \\
\text { G310 } \\
\text { G311 } \\
\text { G313 } \\
\end{array}$ & $\begin{array}{l}\text { G453, G527* } \\
\text { G353, G522* } \\
\text { G358, G515* } \\
\text { G454, G471* } \\
\text { G359, G516* } \\
\text { G363, G533* }\end{array}$ \\
\hline $\begin{array}{l}1(W), 270^{\circ} \\
1(W), 270^{\circ} \\
1(W), 270^{\circ} \\
1(W), 270^{\circ} \\
1(W), 270^{\circ} \\
1(W), 270^{\circ}\end{array}$ & $\begin{array}{l}372 \text { Inches } \\
334 \text { Inches } \\
226 \text { Inches } \\
226 \text { Inches } \\
148 \text { Inches } \\
99 \text { Inches }\end{array}$ & $\begin{array}{l}\text { G315 } \\
\text { G317 } \\
\text { G318 } \\
\text { G319 } \\
\text { G322 } \\
\text { G323 }\end{array}$ & $\begin{array}{l}\text { G364, G534* } \\
\text { G333, G528* } \\
\text { G459, G517* } \\
\text { G460, G536* } \\
\text { G338, G529* } \\
\text { G341, G476* }\end{array}$ \\
\hline Composite & -- & $\cdots$ & G443, G470* \\
\hline
\end{tabular}

*: Heated sample

Table 3-2. PNL Sample Numbers (Welsh, 1993).

\begin{tabular}{|c|c|c|c|c|}
\hline $\begin{array}{c}\text { Riser, } \\
\text { Angle }\end{array}$ & $\begin{array}{c}\text { Depth inches from } \\
\text { the bottom of the } \\
\text { tank }\end{array}$ & Position & $\begin{array}{c}\text { Tank Farm } \\
\text { sample } \\
\text { number }\end{array}$ & $\begin{array}{c}\text { PNL Laboratory } \\
\text { sample number }\end{array}$ \\
\hline $1(\mathrm{NE}), 30^{\circ}$ & 306 Inches & 1 & $\mathrm{G} 300$ & $93-06634$ \\
$1(\mathrm{NE}), 30^{\circ}$ & 125 Inches & 4 & $\mathrm{G} 304$ & $93-06635$ \\
\hline $1(\mathrm{SE}), 150^{\circ}$ & 162 Inches & 9 & $\mathrm{G} 312$ & $93-06636$ \\
$1(\mathrm{SE}), 150^{\circ}$ & 18 Inches & 10 & G314 & $93-06637$ \\
\hline $1(\mathrm{~W}), 270^{\circ}$ & 372 Inches & 11 & $\mathrm{G} 316$ & $93-06638$ \\
$1(\mathrm{~W}), 270^{\circ}$ & 226 Inches & $13 \mathrm{~A}$ & $\mathrm{G} 320$ & $93-06639$ \\
$1(\mathrm{~W}), 270^{\circ}$ & 226 Inches & $13 \mathrm{~B}$ & $\mathrm{G} 321$ & $93-06640$ \\
\hline Field Blank & $\cdots$ & -- & $\mathrm{G} 324$ & $93-06641$ \\
\hline
\end{tabular}


Table 3-3. 102-AP Samples and Requested Analytes (Welsh, 1993).

\begin{tabular}{|c|c|c|c|}
\hline $\begin{array}{l}\text { Tank Farm } \\
\text { Sample } \\
\text { Numbers }\end{array}$ & $\begin{array}{c}\text { Laboratory Sample } \\
\text { Numbors }\end{array}$ & Laboratory & Requested Analytes \\
\hline $\begin{array}{l}\text { G299, G303 } \\
\text { G305, G306 } \\
\text { G308, G309 } \\
\text { G311, G313 } \\
\text { G315, G318 } \\
\text { G319, G323 }\end{array}$ & $\begin{array}{l}\text { G342, G348 } \\
\text { G349, G352 } \\
\text { G353, G358 } \\
\text { G359, G363 } \\
\text { G364, G459 } \\
\text { G460, G341 } \\
\end{array}$ & 222-S Laboratory & 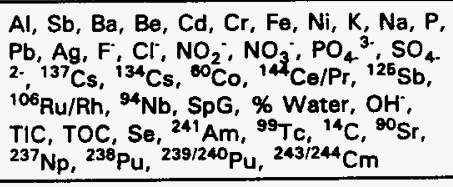 \\
\hline \multirow[t]{2}{*}{$\begin{array}{l}\mathrm{G} 301, \mathrm{G} 302 \\
\mathrm{G} 307, \mathrm{G} 310 \\
\mathrm{G} 317, \mathrm{G} 322\end{array}$} & $\begin{array}{l}\mathrm{G} 449, \mathrm{G} 450 \\
\mathrm{G} 453, \mathrm{G} 454 \\
\mathrm{G} 333, \mathrm{G} 338\end{array}$ & 222-S Laboratory & 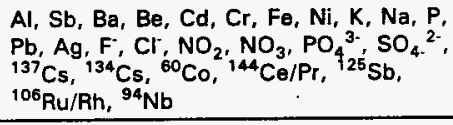 \\
\hline & $\begin{array}{l}\text { Composite sample } \\
\text { G443, G470 }\end{array}$ & 222.S Laboratory & 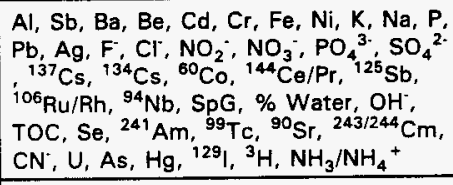 \\
\hline $\begin{array}{l}\text { G300, G304 } \\
\text { G312, G314 } \\
\text { G316, G320 } \\
\text { G321 }\end{array}$ & $\begin{array}{c}93-06634,93-06635 \\
93-06636,93,06637 \\
93-06638,93-06639 \\
93-06640\end{array}$ & PNL & $\begin{array}{l}\text { Volatiles, Semivolatiles, EDTA, HEDTA, } \\
\text { Citrate, Oxalate, Glycolate }\end{array}$ \\
\hline
\end{tabular}

EDTA: ethylenediaminetetraacetic acid.

HEDTA: N-(2-hydroxyethyl)ethylenediaminetriacetic acid. 


\subsection{SAMPLE HANDLING AND ANALYTICAL SCHEME}

\subsection{WASTE DESCRIPTION}

At the time the samples were collected, all samples were a clear, yellowish liquid free of solids (Duchsherer, 1993). The samples were stored outdoors at ambient temperatures for the first 24 hours. During this initial storage period, a white precipitate formed in the bottom of each sample bottle. The samples were subsequently moved indoors and stored at room temperature in an effort to resolubilize the precipitate. However, the solid precipitate remained in the sample bottles

From this observation, it was assumed that low temperature conditions will likely lead to the formation of solid precipitates in Tank 241-AP-102. The waste previously contained in Tank 241-AN-106, the predominant source of the waste in Tank 241-AP-102, existed in two layers: high phosphate salts on top and high sodium salts on bottom. When the two layers are mixed at temperatures below $81^{\circ} \mathrm{F}$, such as occurred after tank sampling, a solid precipitate forms. However, this precipitate can be resolubilized upon heating to at least 104 ${ }^{\circ} \mathrm{F}$. The waste was transferred from Tank 241-AN-106 "in place," to minimize mixing of the two layers and possible precipitation of solids. Prior to sampling Tank 241-AP-102, the tank was mixed and the temperature elevated from $71^{\circ} \mathrm{F}$ to $81^{\circ} \mathrm{F}$. It was predicted that, during this mixing prior to sampling, some solid precipitation of hydrated sodium phosphate may have occurred (Hendrickson et al., 1993).

Westinghouse Hanford Company 222-5 Process and Analytical Laboratory personnel described the solid precipitate crystals as approximately 3 to $5 \mathrm{~mm}$ long, prismatic in shape, with the length exceeding the width by a factor of 5 to 10 . Inspection by polarized light microscopy of one of the smaller crystals revealed six-sided prisms, typical for hydrated sodium phosphate $\left(\mathrm{Na}_{3} \mathrm{PO}_{4} \bullet 12 \mathrm{H}_{2} \mathrm{O}\right)$ crystals. This observation was supported by the birefringence (difference between refractive indexes in $x$ and $y$ directions) which was characteristic of hydrated sodium phosphate. Based upon this evidence and the chemistry of the sample, it was concluded that the precipitate was hydrated sodium phosphate (Duchsherer, 1993).

\subsection{HOLD TIME CONSIDERATIONS}

For a description of hold time considerations, see the Tank Characterization Reference Guide (De Lorenzo, et al., 1994).

\subsubsection{WHC - Process and Analytical Laboratories}

Tank 241-AP-102 was sampled on 04/28, 04/29, and 04/30/1993. The samples were delivered to the Westinghouse Hanford Company 222-S Process and Analytical Laboratory on $05 / 01 / 93$ and placed in the care of laboratory personnel. Aliquots were then submitted to the 222-S Laboratory for analysis. The acid digestion for the individual inductively coupled plasma (ICP) samples was conducted on 05/20/93 and ICP analyses were completed on $07 / 15 / 93$. A composite sample was prepared on $05 / 14 / 93$ and acid digestion of the composite was completed on $05 / 18 / 93$. The ICP metal analysis for the composite was completed on $07 / 01 / 93$. 


\subsubsection{Pacific Northwest Laboratory - Analytical Chemistry Laboratory}

The volatile organic analysis (VOA) and semivolatile organic analysis (SVOA) samples were delivered to the Pacific Northwest Laboratory (PNL) Analytical Chemistry Laboratory on 05/03/93. The samples for the remaining analyses were received on $07 / 16 / 93$ and $07 / 21 / 93$.

Eight samples from Tank 241-AP-102 were delivered to PNL for VOA, SVOA, glycolate, oxalate, EDTA/HEDTA, and citrate analyses. All analyses were completed within a 14-day holding time based on sample receipt (Duchsherer, 1993). Maximum holding time limits for EDTA/HEDTA, citrate, glycolate, and oxalate have yet to be determined.

\subsection{SAMPLE PREPARATION}

Routine sample preparation procedures are discussed in the Tank Characterization Reference Guide (De Lorenzo et al., 1994). Additional procedures specific to this tank are described below.

\subsubsection{Adjustments Due to Solid Precipitate}

The presence of solid precipitate in samples taken from Tank 241-AP-102 required evaluation of the analytical methods used to detect the analytes. This evaluation was necessary to determine if the presence of the precipitate skewed the analytical results, and if so, what corrective actions needed to be taken. A description of the activities which took place at the 222-S Laboratory as a result of the solid precipitate is given below.

Upon discovery of the precipitate crystals, a technique was developed to keep the solids in solution prior to subsequent analysis. This technique involved gentle heating of the samples immediately prior to sample analysis, followed by a brief cooling period in order to obtain accurate volume measurements. This procedure was not communicated to a!l personnel working within the 222-S Laboratory, and analyses were performed on samples containing solids. Recognition of this error resulted in the development of a recovery plan which included the following items (Duchsherer, 1993):

- Each analytical method was reviewed to determine which ones would likely dissolve solids as part of the procedural steps. It was found that only inductively coupled plasma (ICP) and atomic absorption methods employed an acid digest (heating/dilution) preparation step, to adequately solubilize any solids prior to analysis.

- All samples were reanalyzed for those elements that comprised the solid compound.

- Four samples were picked at random to be reanalyzed for the fulf protocol of constituents. The only constituents that were omitted were those in which the analytical method employed a digestion/heating step. This was performed in order to demonstrate that no constituents other than those found comprising the hydrated sodium phosphate were carried down or co-precipitated with the solids.

\footnotetext{
LATA-TCR-9401, Rev. $1 \quad 4-2$
} 
Based on the results of the sodium phosphate precipitate crystals (see Section 4.1), the laboratory concluded that as long as no other constituents co-precipitated, sodium and phosphorous were the only analytes that needed to be redetermined. Sodium and elemental phosphorous were determined by ICP from samples prepared by acid digestion; therefore they were not reanalyzed. New samples, heated aliquots from each parent sample, were obtained for redetermination of phosphate by ion chromatography (IC) analysis. Special handling instructions accompanied the new aliquots to prevent the reformation of solids. To determine if any other anions were carried down with the sodium phosphate, four of the above samples submitted for IC analyses were reanalyzed for all constituents in the full grout characterization protocol.

As discussed in section 5.1.2, results from the analyses performed on the heated samples revealed consistently higher concentrations of both phosphate and sulfate anions. Therefore, the final reported concentrations of both phosphate and sulfate within Tank 241 AP-102 are based on the heated samples. Interpretation and discussion of the results from the heated samples is addressed in Section 5.1.2 of this report.

\subsection{ANALYTICAL METHODS}

This section briefly describes the analytical methods used to characterize the waste in Tank 241-AP-102, as well as those methods used to characterize the grout product produced from composite samples from the tank.

\subsubsection{Physical Tests}

Physical tests performed on the samples included weight percent water and specific gravity $\{\mathrm{SpG}$. The weight percent water procedure used approximately $1 \mathrm{ml}$ of sample, which was heated in an oven at $120^{\circ} \mathrm{C}$ for $18 \pm$ hours. The weight percent water was performed on all individual and composite samples in duplicate. The specific gravity analysis was performed on samples submitted for full characterization and the composite sampies.

\subsubsection{Homogeneity of Waste}

Statistical analysis of the sodium, phosphate, and ${ }^{137} \mathrm{Cs}$ results was performed to determine the homogeneity of Tank 241-AP-102 (see Section 7.2 for a discussion of tank waste homogeneity). Data taken from 18 of the 25 samples taken from Tank 241-AP-102 were used to determine if the tank contents were homogeneous. The 18 samples consisted of 15 original samples and 3 duplicates. The following analyses were performed by the 222-S Laboratory on the samples: gamma energy analysis (GEA) for ${ }^{137} \mathrm{Cs}$; ICP for sodium; and IC for phosphate. The tank waste was determined to be homogeneous after an analysis of variance (ANOVA) was performed on the results. The statistical method and results of this analysis may be found in Sections 7.2 and 7.3 of this characterization report. Determination of homogeneity early in the laboratory work allowed for preparation of a composite sample and conduction of the product tests concurrently with the comprehensive testing of the individual samples. 


\subsubsection{Chemical and Radionuclide Constituent Analysis}

Tweive of the 18 samples used in the homogeneity analyses were randomiy selected and tested for chemical and radionuclide constituents. The 12 samples consisted of 3 samples from each riser and 3 duplicates. From each of the 12 samples, two subsamples were taken for a total of $\mathbf{2 4}$ samples analyzed. Additionally, two subsamples from the composite sample (see Section 4.4.5) were analyzed for chemical and radionuclide composition. Table 4-1 lists the analytical methods.

Table 4-1. Analytical Methods (Hendrickson et. al., 1993). (2 pages)

\begin{tabular}{|c|c|c|}
\hline Analyte & Method & Procedure \\
\hline $\mathrm{Hg}$ & CVAA $^{1}$ & LA-325-104 \\
\hline As, Se & GHAA $^{2}$ & $\begin{array}{l}\text { LA-355-131 } \\
\text { LA-365-131 }\end{array}$ \\
\hline $\begin{array}{l}{ }^{238} \mathrm{Pu},{ }^{239 / 240} \mathrm{Pu},{ }^{241} \mathrm{Am}, \\
{ }^{243 / 244} \mathrm{Cm},{ }^{237} \mathrm{~Np}\end{array}$ & separation/Alpha/AEA ${ }^{3}$ & $\begin{array}{l}\text { LA-503-156 } \\
\text { LA-933-141 }\end{array}$ \\
\hline $\begin{array}{l}\mathrm{Ag}, \mathrm{Ba}, \mathrm{Cd}, \mathrm{Cr}, \mathrm{Na}, \mathrm{Ne} \\
\mathrm{Pb}, \mathrm{P}, \mathrm{Al}, \mathrm{Be}, \mathrm{Sb}, \mathrm{Fe}\end{array}$ & Inductively Coupled Plasma & $\begin{array}{l}\text { LA-503-156 } \\
\text { LA-508-051 } \\
\text { LA-505-151 }\end{array}$ \\
\hline $235.237,238 \mathrm{U}$ & Uranium & LA-925-106 \\
\hline $\mathrm{NH}_{3}$ & Kjeldaht $^{4}$ & LA-634-102 \\
\hline $\mathrm{CN}^{-}$ & Dist/Spec 5 & LA- $695-102$ \\
\hline $\mathrm{F}, \mathrm{Cl}^{-}, \mathrm{NO}_{2}^{-}, \mathrm{NO}_{3} ;, \mathrm{SO}_{4}{ }^{2-}, \mathrm{PO}_{4}{ }^{3-}$ & Ion Chromatography & LA-533-105 \\
\hline TOC & Total Organic Carbon & LA-344-105 \\
\hline $\mathrm{CO}_{3}{ }^{2-}$ & Total Inorganic Carbon & LA-622-102 \\
\hline${ }^{90} \mathrm{Sr}$ & separation/Beta ${ }^{5}$ & LA-220-101 \\
\hline${ }^{99} \mathrm{Tc}$ & separation/LSC 6 & LA-438-101 \\
\hline${ }^{14} \mathrm{C}$ & separation/LSC & LA-348-104 \\
\hline $\begin{array}{l}{ }^{134} \mathrm{Cs},{ }^{137} \mathrm{Cs},{ }^{94} \mathrm{Nb},{ }^{106} \mathrm{Ru} / \mathrm{Rh},{ }^{125} \mathrm{Sb}, \\
{ }^{144} \mathrm{Ce},{ }^{60} \mathrm{Co}\end{array}$ & Gamma Energy Analysis & $\begin{array}{l}\text { LA-548-121 } \\
\text { LA-508-052 }\end{array}$ \\
\hline${ }^{129} \mathrm{I}$ & separation/LE GEA ${ }^{7}$ & LA-378-103 \\
\hline${ }^{3} \mathrm{H}$ & separation/LSC & LA-218-104 \\
\hline
\end{tabular}

${ }^{1}$ Cold Vapor Atomic Absorption

${ }^{2}$ Gaseous Hydride Atomic Absorption

${ }^{3}$ Chemical Separation along with Alpha Proportional Counting and Alpha Energy Analysis

${ }^{4}$ Ammonia analysis by caustic addition, distillation, and capture in a boric acid solution

${ }^{5}$ Chemical Separation along with total Beta Proportional Counting

${ }^{6}$ Chemical Separation followed by Liquid Scintillation Counting

${ }^{7}$ Chemical Separation followed by Low Energy Gamma Energy Analysis 


\subsubsection{Volatile and Semivolatile Organic Constituent Analysis}

Seven samples of waste from Tank 241-AP-102 were analyzed for volatile and semivolatile constituents by Pacific Northwest Laboratories (PNL). The seven samples (six samples plus one duplicate) were tested using the following methods (Hendrickson et al., 1993):

- Rapid screening by Headspace/Ges Chromatography to establish laboratory dilution requirements. PNL procedure PNL-ALO-331 is a modified version of EPA Method 3810 (EPA, 1986).

- Extracting the non-polar organics into Hexane or Isooctane followed by Gas Chromatography $(G C)$ for volatile component analysis. PNL procedure PNLALO-335 follows the USEPA Contract Laboratory Program (CLP) Statement of Work (EPA, 1991).

- Gas Chromatograph Mass Spectrometry for semivolatile component analysis. PNL procedure PNL-ALO-345 follows the CLP protocol (EPA, 1991).

Quality assurance techniques of EPA methods cited were followed as closely as technically feasible. Section 7.5 of this report addresses the data validation findings from the analyses performed above.

\subsubsection{Preparation of Composite Sample}

Upon determination that Tank 241-AP-102 was homogeneous, a composite sample was generated from each of the 15 original samples (not duplicate). Before generating the composite sample, each of the original samples were brought to ambient conditions by incubation in an ultrasonic water bath for about $\mathbf{3 0}$ minutes and were vigorously mixed for approximately the last 5 minutes of this incubation. At the conclusion of the incubation/mixing period, $70 \mathrm{~mL}$ from each of the 15 original inorganic samples were combined to create the composite sample.

\subsubsection{Grout Product Tests}

Product tests of the final grout waste were conducted with material prepared from the composite samples (Welsh, 1993). Analyses included individual tests for viscosity, critical flow rate, frictional pressure drop, density, 10 minute gel strength, and drainable liquid (\%v/v) after 28 days. The cured grout specimens were tested for compressive strength at 28 days, toxicity characteristic leaching procedure, and leach indices over 5 days with two of the three indices extended to 90 days. Additional assays regarding gas generation testing for the determination of radiolytic generation of hydrogen, nitrous oxides, and possibly other gases as the grout cured were performed on the hot grout samples. Proper procedures and protocols for the grout product tests can be found in Hendrickson, et al. (1993). The results from the grout product tests are not reported in this document since they do not reflect the contents of Tank 241-AP-102 and are not relevant to its characterization. 


\subsection{MODULE SPECIFIC ANALYSES}

The characterization program for Tank 241-AP-102 was intended to satisfy criteria set by the Tank Waste Remediation System (TWRS) and the Hanford Grout Disposal Program (HGDP). The TWRS sample characterization objectives are to provide adequate characterization of physical, chemical and radiological properties of Hanford Site tank wastes to support the resolution of Unreviewed Safety Questions, other safety issues surrounding the Watch List tanks, and the design of retrieval, pretreatment and final disposal systems (Bell, 1993). The HGDP was one of the program elements of the TWRS designed for the retrieval and final disposal of low level wastes prior to a policy change eliminating grout as a disposal option. The needs of the HGDP are separate and in addition to those of the TWRS.

Low level waste from Tank 241-AP.102 was designated as potential feed for the (now terminated) Grout Treatment Facility (GTF). Having received this designation, the waste in Tank 241-AP-102 was sampled, analyzed, and tested to determine feed processability and to demonstrate compliance with regulatory requirements. The analytical requirements for the Grout Program not only entailed determination of the waste's suitability for disposal as grout, but also included determination of the grout product's physical and chemical characteristics to ensure regulatory compliance. 


\subsection{ANALYTICAL RESULTS AND WASTE INVENTORY}

The chemical, radiochemical, physical, and organic complexant results associated with Tank 241-AP-102 are presented in Appendix A, Tables A-1 through A-5. Data corresponding to the volatile and semivolatile organic analyses are found in Tables A-6 through A-8. Table 5-1 summarizes, the presentation layout of the analytical data in Appendix A. The samples from which these results were derived were collected between 4-28-93 and 4-30-93 after the waste had been thoroughly blended by the action of a mixer pump. This sampling event was the most recent regarding Tank 241-AP-102 and reflects the most accurate characterization of the tank waste available at the present time. A detailed discussion of the sampling process was presented in Section 3.

Table 5-1. Analytical Data Presentation Tables.

\begin{tabular}{|c|l|}
\hline Table & \multicolumn{1}{|c|}{ Analyses } \\
\hline A-1 & Metals \\
\hline A-2 & lons \\
\hline A-3 & Radionuclides \\
\hline A-4 & Organic Complexants \\
\hline A-5 & Physical Properties \\
\hline A-6 & Volatile Organics \\
\hline A-7 & Semivolatile Organics \\
\hline A-8 & Organic Compounds \\
\hline $5-7$ & Tank Characterization Report Results \\
\hline
\end{tabular}

In cases where a duplicate analysis was performed on a sample, the data presented in the Appendix A tables were obtained by calculating an average concentration value from the initial and duplicate results. If an analyte was detected by the original but not by the duplicate sample evaluation, or vise-versa, only the single positive result was reported. When both sample runs failed to detect an analyte, the detection limit preceded by a less than $(<)$ sign was recorded as the sample results.

A representative tank concentration for each analyte was included in the Appendix $A$ tables. Most of these values were derived according to a statistical model (Welsh, 1993) and were accompanied by a standard error estimate. When the statistical model could not be applied due to insufficient data, representative tank concentrations were obtained by calculating simple averages. If all available sample analyses failed to detect a particular analyte, the tank concentration of the analyte was reported to be less than the highest recorded detection limit. Detection limit values were not utilized in any of the calculations from which representative tank concentration values and standard error estimates were derived. 
The range of the tabulated sample data associated with each analyte was also included in the Appendix A tables. The projected tank inventory value reported in the Appendix A tables was obtained by multiplying the representative tank concentration of each analyte by the volume of waste in the tank. At the time of sampling, the tank contained $4.18 \mathrm{E}+06$ liters of waste. The appropriate conversion factors were included in the calculations to obtain the reported units.

\subsection{CHEMICAL ANALYSES}

\subsubsection{Elemental Constituents}

The following analytes were evaluated by ICP: $\mathrm{Al}, \mathrm{Sb}, \mathrm{Ba}, \mathrm{Be}, \mathrm{Cd}, \mathrm{Cr}, \mathrm{Fe}, \mathrm{Ni}, \mathrm{K}, \mathrm{Na}$, $\mathrm{P}, \mathrm{Pb}$, and $\mathrm{Ag}$. Arsenic and selenium were analyzed by GHAA, and mercury was determined by CVAA. The laser fluorimetry method was utilized to evaluate uranium. As previously mentioned in Section 4, sodium phosphate apparently precipitated from the samples. The potential for obtaining artificially low sodium and phosphorus results due to the formation of sodium phosphate precipitate in samples designated for ICP analysis was eliminated by the acid digestion preparation step; therefore, the precaution of storing aliquots at elevated temperatures to prevent precipitation was deemed to be unnecessary. As a consequence, results obtained from the few available heated samples were not included in the determination of mean analyte concentrations of Tank 241-AP-102 unless specifically stated otherwise.

Sodium is the major elemental constituent in Tank 241-AP-102 and exhibits a concentration of $85,000 \mathrm{ppm}$. Of the remaining detected metal or elemental constituents, the concentrations of aluminum, chromium, phosphorous, and potassium exceeded $500 \mathrm{ppm}$ and were relatively high compared to the remaining analytes. Mercury and silver were evaluated by the laboratory, but their concentrations proved to be below their corresponding detection limits.

With respect to uranium, two separate runs, each consisting of initial and duplicate analyses, were conducted on the unheated composite sample. These results were then confirmed by the analysis of four samples which were preserved under elevated temperature conditions. The representative tank concentration of uranium wa, therefore, derived from data obtained from both heated and unheated samples.

Arsenic was only detected in the composite sample, G443. The analysis of severa! samples which were stored at $40^{\circ} \mathrm{C}$ failed to detect arsenic and were not recorded in Appendix A. The reported arsenic value, therefore, represents a worse case estimate.

Elemental constituents, for which both laboratory data and historical estimates are available, are listed in Table 5-2. Relative percent differences were calculated in order to facilitate their comparison. 
Table 5-2. Comparison of Analytical and Historical Estimates of Elemental Constituents in Tank 241-AP-102.

\begin{tabular}{|c|c|c|c|}
\hline Analyte & $\begin{array}{l}\text { Leporatory } \\
\text { Romilt } \\
\text { (og/t) }\end{array}$ & $\begin{array}{l}\text { Olistorical } \\
\text { Estimate } \\
\left(\omega_{g} \mathrm{~L}\right)\end{array}$ & $\begin{array}{l}\text { Relative } \\
\text { Percent } \\
\text { Difference }\end{array}$ \\
\hline Al & 1.67E + 06 & $8.17 E+06$ & $35 \%$ \\
\hline As & 88.7 & 63.4 & $33 \%$ \\
\hline $\mathrm{Ba}$ & 284 & $<11,100$ & N/A \\
\hline $\mathrm{Cd}$ & 1,470 & $<49,000$ & N/A \\
\hline $\mathrm{Cr}$ & 618,000 & 496,000 & $22 \%$ \\
\hline $\mathrm{Fe}$ & 3,810 & $<6,900$ & N/A \\
\hline $\mathrm{Pb}$ & 3,290 & $<460,000$ & N/A \\
\hline $\mathrm{Hg}$ & $<5.00$ & $<50$ & N/A \\
\hline$P$ & $3.06 E+06$ & $6.05 E+06$ & $66 \%$ \\
\hline K & $1.29 E+06$ & $9.50 \mathrm{E}+0.5$ & $30 \%$ \\
\hline $\mathrm{Se}$ & 367 & 118 & $103 \%$ \\
\hline $\mathrm{Ag}$ & $<125$ & $<3.630$ & N/A \\
\hline $\mathrm{Na}$ & $1.02 E+08$ & $8.10 E+07$ & $23 \%$ \\
\hline$U$ & 4,620 & 3,520 & $27 \%$ \\
\hline
\end{tabular}

\subsubsection{Anions}

The following anions were determined by ion chromatography (IC): fluoride, chloride, nitrite, nitrate, sulfate, and phosphate. The samples involved with the IC analyses were analogous to those utilized in the ICP evaluations; however, two complete sets of data were reported by the laboratory for the IC analytes. One set of data was derived from samples which were stored at ambient temperature during the time interval between collection and analysis; sadium phosphate had precipitated in this group. The second set of results was obtained from samples which were heated to $40^{\circ} \mathrm{C}$ prior to their analysis. The elevated temperature prevented sodium phosphate precipitation and allowed the entire phosphate component to be appropriately analyzed in solution.

The greater sulfate concentrations observed in the heated versus unheated specimens indicated that a sulfate salt, in addition to a phosphate salt, may have also precipitated from the samples, but the sulfate salt is not likely to be a sodium derivative. This possibility is supported by the solubility data listed in Table 5-3 obtained from the CRC Handbook of Chemistry and Physics, (Lide, 1991-92). 
Table 5-3. Solubility of Common Sodium Salts.

\begin{tabular}{|l|c|}
\hline \multirow{2}{*}{ salt } & $\begin{array}{c}\text { Solubility in Watar } \\
\text { g/To0 mL }\end{array}$ \\
\hline $\mathrm{Na}_{3} \mathrm{PO}_{4} \cdot 12 \mathrm{H}_{2} \mathrm{O}$ & 1.5 \\
\hline $\mathrm{Na}_{2} \mathrm{SO}_{4} \cdot 7 \mathrm{H}_{2} \mathrm{O}$ & 19.5 \\
\hline $\mathrm{NaCl}$ & 35.7 \\
\hline $\mathrm{NaNO}_{2}$ & 81.5 \\
\hline $\mathrm{NaNO}_{3}$ & 92.1 \\
\hline
\end{tabular}

The heptahydrate of sodium sulfate is considerably less soluble in water than the corresponding chloride, nitrite, and nitrate salts but not nearly as insoluble as the dodecahydrate of sodium phosphate. This information is consistent with the laboratory findings which concluded that the precipitate was hydrated sodium phosphate, and results from solubility product calculations demonstrate that sodium sulfate heptahydrate will not precipitate with respect to the reported ion concentrations in the tank. Since the multivalent nature of sulfate, as well as phosphate, contributes to decreased solubility compared to the monovalent anions, it is still reasonable to suspect sulfate to precipitate to some extent. As a consequence, the data listed for $\mathrm{F}, \mathrm{Cl}, \mathrm{NO}_{2}{ }^{\circ}$, and $\mathrm{NO}_{3}{ }^{\circ}$ in Table A-2 were derived from unheated samples; the sulfate and phosphate results were acquired from the heated specimens.

Another explanation regarding the observed increase in the sulfate concentration derived from heated versus non-heated samples involves the possible dissociation of a complex ion. When sulfate acts as a ligand in a complex ion, it cannot be detected by ion chromatography. An increase in temperature could cause the dissociation of a hypothetical complex ion and allow a larger number of free sulfate ions to be analyzed. This argument is somewhat supported by the nitrate results, since several samples exhibited higher concentration values after having been heated. The chloride and nitrite data, however, seem to contradict the complex ion theory.

Fluoride was not detected in any of the samples by the $I C$ analyses and was further evaluated by an ion selective electrode (ISE) method; however, the anion failed to be detected by the ISE technique as well. According to the data validation report (Duchsherer, 1993), the IC data were considered to be more reliable than the ISE results; therefore, the detection limit associated with the IC analyses was recorded in Table A-2.

The only detectable cyanide data for Tank 241-AP-102 was obtained from sample G443, the composite sample, at an average tank concentration of $24.6 \mu \mathrm{g} / \mathrm{mL}$. Several samples which were stored at $40^{\circ} \mathrm{C}$ were analyzed for cyanide and yielded consistently lower results when compared to the unheated composite specimen. The data from heated samples were, therefore, disregarded in order to avoid calculating a mean tank cyanide concentration possessing a low bias. 
Comparisons between the laboratory data and historical estimates associated with ammonia and the anionic constituents are presented in Table 5-4. The reported analytical carbonate value was calculated from the total inorganic carbon data. Table 5-4 also demonstrates that the ion chromatography phosphate result shows better agreement with the historical estimate that the ICP derived phosphate value.

Table 5-4. Comparison of Analytical and Historical Estimates of Anionic Constituents in Tank 241-AP-102.

\begin{tabular}{|c|c|c|c|}
\hline Analyte & $\begin{array}{l}\text { Poratory } \\
\text { Result } \\
\text { (mghl }\end{array}$ & $\begin{array}{l}\text { Histeical } \\
\text { Estimate } \\
\text { (wod) }\end{array}$ & $\begin{array}{l}\text { Rolowive } \\
\text { Perent } \\
\text { Diterence }\end{array}$ \\
\hline Ammonia & 273,000 & 108,000 & $87 \%$ \\
\hline Carbonate & $2.68 E+07$ & $1.74 E+07$ & $43 \%$ \\
\hline Chloride & $2.90 E+06$ & $2.16 E+06$ & $29 \%$ \\
\hline Cyanide & 24,600 & 5,280 & $129 \%$ \\
\hline Fluoride & $<168,000$ & $<61,600$ & N/A \\
\hline Hydroxide & $9.15 E+06$ & $7.09 E+06$ & $25 \%$ \\
\hline Nitrate & $7.82 E+07$ & $6.03 E+07$ & $26 \%$ \\
\hline Nitrite & $3.80 E+07$ & $2.60 E+07$ & $38 \%$ \\
\hline Phosphate $(\mid \mathrm{C})$ & $1.16 E+07$ & $1.80 E+07$ & $43 \%$ \\
\hline Phosphate (ICP) & $9.38 E+06$ & $1.80 E+07$ & $63 \%$ \\
\hline Sulfate & $4.51 E+06$ & $2.06 E+06$ & $75 \%$ \\
\hline
\end{tabular}

\subsection{RADIOLOGICAL DETERMINATIONS}

The major radioactive constituents in the waste were ${ }^{137} \mathrm{Cs}$ and ${ }^{90} \mathrm{Sr} ;{ }^{99} \mathrm{Tc}$ and ${ }^{60} \mathrm{Co}$ were present to a lesser extent. Of the alpha emitting isotopes, only ${ }^{241} \mathrm{Am}$ demonstrated a detectable activity. The results from the tritium analyses were qualified as unusable due to poor matrix spike recoveries; however, the tritium value reported by the laboratory is relatively unimportant since it is dwarfed by the ${ }^{137} \mathrm{Cs}$ activity. The analytical and historical results pertaining to several isotopes are listed in Table 5-5.

\subsection{ORGANIC CONSTITUENTS}

Most of the target analytes associated with the volatile and semivolatile organic analyses were not detected in the waste. However, detectable concentrations of acetone, 2-butanone, toluene, and 1-butanol were reported by the laboratory, and their individual sample results are specifically tabulated in Appendix A.

The total organic carbon (TOC) analysis revealed the presence of $3.28 \mathrm{~g} / \mathrm{L}$ of carbon in Tank 241-AP-102, and this result was consistent with the historical estimate. A list of organic complexants which were expected to account for some of the total organic carbon detected in the tank waste is presented in Table 5-6; the concentration of each ligand and the concentration of carbon associated with each ligand were also reported. 
Table 5-5. Comparison of Analytical and Historical Isotopic Results for Tank 241-AP-102.

\begin{tabular}{|c|c|c|c|}
\hline Analyte & $\begin{array}{c}\text { Laboratory } \\
\text { Result } \\
\text { (vell) }\end{array}$ & $\begin{array}{l}\text { Ifistorical } \\
\text { Estimate } \\
\text { (UCIL) }\end{array}$ & $\begin{array}{l}\text { Reletrve } \\
\text { Percent } \\
\text { Bifference }\end{array}$ \\
\hline${ }^{137} \mathrm{Cs}$ & 228,000 & 180,000 & $24 \%$ \\
\hline${ }^{90} \mathrm{Sr}$ & 1,440 & 1,960 & $31 \%$ \\
\hline${ }^{14} \mathrm{C}$ & 0.499 & 0.295 & $51 \%$ \\
\hline${ }^{99} \mathrm{Tc}$ & 85.6 & 60.7 & $34 \%$ \\
\hline${ }^{60} \mathrm{Co}$ & 76.3 & $<9$ & N/A \\
\hline${ }^{241} \mathrm{Am}$ & 0.419 & 0.534 & $24 \%$ \\
\hline
\end{tabular}

Table 5-6. Organic Complexant Concentration Data.

\begin{tabular}{|l|c|c|}
\hline $\begin{array}{c}\text { Complexant } \\
\text { or } \\
\text { Ligand }\end{array}$ & $\begin{array}{c}\text { grams of } \\
\text { CoMPLEXANT } \\
\text { per liter (g/L) }\end{array}$ & $\begin{array}{c}\text { grams of } \\
\text { CARBON } \\
\text { per liter }(g / \mathrm{L})\end{array}$ \\
\hline Citrate & 0.515 & 0.196 \\
\hline EDTA & 0.519 & 0.216 \\
\hline HEDTA & 0.110 & 0.048 \\
\hline Glycolate & 1.10 & 0.352 \\
\hline Oxalate & 0.760 & 0.207 \\
\hline \multicolumn{2}{|c|}{ Total Carbon from Analyzed Complexants } & 1.02 \\
\hline
\end{tabular}

As demonstrated in the table, the amount of carbon attributable to these complexants is $1.02 \mathrm{~g} / \mathrm{L}$ and accounts for approximately $30 \%$ of the $3.28 \mathrm{~g} / \mathrm{L} \mathrm{TOC}$ value. Since the organic carbon contribution from volatile and semivolatile organic compounds in Tank 241-AP102 is negligible, the remaining organic carbon in the waste is attributed to the presence of additional complexants, either intact molecules or decomposition products. 


\subsection{PHYSICAL PROPERTIES}

\subsubsection{Specific Gravity, Percent Water, and pH}

The specific gravity and percent water results from the tank samples agreed within $3 \%$ and $4 \%$, respectively, of the historic tank content estimated values (see Table 5-7). The determined values for the specific gravity and percent water of the waste are $1.20 \mathrm{~g} / \mathrm{cm}^{3}$ and $75.0 \%$ respectively. The $\mathrm{pH}$ of the waste in Tank 241-AP-102 was calculated from the hydroxide ion concentration and reported to be 13.7. The historical pH estimate was 13.6.

\subsubsection{Rheology}

Due to the lack of rheology measurements, the viscosity of the tank waste was estimated. The specific gravity of the waste is $1.20 \mathrm{~g} / \mathrm{ml}$, and according to the Total Dissolved Solid's analysis, the percentage of water, by weight, is $75 \%$. Since a $25 \%$, by weight, sodium chloride solution has a specific gravity of 1.19 , its corresponding viscosity of 1.9 centipoise $(0.0013 \mathrm{lbs} / \mathrm{ft}$. sec) was considered to be the viscosity of the waste. It is recommended, however, that the viscosity be determined experimentally by a laboratory.

\subsubsection{Energetics}

Energetics were not analyzed as part of the test suite of assays because the high water content of the double-shell tank waste makes them unlikely candidates for an exothermic reaction occurring under the present tank operating conditions.

\subsection{DATA PRESENTATION}

The Tank Characterization Report Results recorded in Table 5-7 are the final constituent estimates for this document. The values are equal to the representative tank concentrations presented in the Appendix A tables. Exceptions have either been previously or are subsequently discussed in this text. If laboratory results were not available for an analyte, the Tank Characterization Result was, if possible, derived from historical data. 
Table 5-7. Tank Characterization Report Data for Double-Shell Tank 241-AP-102. (3 pages)

\begin{tabular}{|c|c|c|c|c|}
\hline Analvte & $\begin{array}{l}\text { Historic Tank } \\
\text { Content } \\
\text { Estimate }\end{array}$ & Chara & tion & $\begin{array}{l}\text { Total } \\
\text { Tenk } \\
\text { Inventory }\end{array}$ \\
\hline Motals & $(\mu g / \mathrm{L})$ & $(4 \mathrm{gu})$ & $\mu g / g$ & $(\mathbf{k g})$ \\
\hline Aluminum (Al) & $8.17 E+06$ & $1.16 \mathrm{E}+07$ & 9,670 & 48,500 \\
\hline Antimony (Sb) & $\bar{\cdots}$ & 6,610 & 5.51 & 27.6 \\
\hline Arsenic (As) & 63.4 & 88.7 & 0.0739 & 0.371 \\
\hline Barium (Ba) & $<11,100$ & 284 & 0.237 & 1.19 \\
\hline Beryllium (Be) & $\cdots$ & 146 & 0.122 & 0.610 \\
\hline Bismuth (Bi) & $<1.45 \mathrm{E}+05$ & $\cdots$ & $<121$ & $<606$ \\
\hline Boron (B) & 600 & -- & 0.00209 & 2.51 \\
\hline Cadmium (Cd) & $<49,600$ & 1,470 & 1.23 & 6.14 \\
\hline Calcium (Ca) & 80,000 & $\cdots$ & 66.7 & 334 \\
\hline Chromium $(\mathrm{Cr})$ & $4.96 \mathrm{E}+05$ & $6.18 E+05$ & 515 & 2,580 \\
\hline Copper (Cu) & $<3,750$ & $\cdots$ & $<3.13$ & $<15.7$ \\
\hline Iron (Fe) & $<6,900$ & 3,810 & 3.18 & 15.9 \\
\hline Lead $(\mathrm{Pb})$ & $<4.60 E+05$ & 3,290 & 2.74 & 13.8 \\
\hline Magnesium (Mg) & 2,630 & --- & 2.19 & 11.0 \\
\hline Manganese (Mn) & $<55,700$ & -- & $<46.4$ & 233 \\
\hline Mercury $(\mathrm{Hg})$ & $<50$ & $<5.00$ & $<0.00417$ & $<0.0209$ \\
\hline Molybdenum (Mo) & $<66,600$ & $\cdots$ & $<55.5$ & $<278$ \\
\hline Neptunium (Np) & $<3,000$ & $\ldots$ & $<2.50$ & $<12.5$ \\
\hline Nickel (Ni) & -- & 26,600 & 22.2 & 111 \\
\hline Phosphorus (P) & $6.05 E+06$ & $3.06 E+06$ & 2,550 & 12,800 \\
\hline Potassium (K) & $9.50 E+05$ & $1.29 E+06$ & 1,080 & 5,390 \\
\hline Selenium (Se) & 118 & 0.367 & 0.306 & 1.53 \\
\hline Silicon (Si) & 480 & -- & 0.400 & 2.01 \\
\hline Silver $(\mathrm{Ag})$ & $<3,630$ & $<125$ & $<0.104$ & $<0.523$ \\
\hline Sodium (Na) & $8.10 E+07$ & $1.02 \mathrm{E}+08$ & 85,000 & $4.26 E+05$ \\
\hline Titanium (Ti) & $<3,510$ & $\cdots$ & $<2.93$ & 14.7 \\
\hline Uranium (U) & 3.520 & 4,620 & 3.85 & 19.3 \\
\hline $\operatorname{Zine}(Z n)$ & $<9,440$ & $\cdots$ & $<7.87$ & $<39.5$ \\
\hline Zirconium $(\mathrm{Zr})$ & $<27,800$ & $\cdots$ & $<23.2$ & $<116$ \\
\hline
\end{tabular}


Table 5-7. Tank Characterization Report Data for Double-Shell Tank 241-AP-102. (3 pages)

\begin{tabular}{|c|c|c|c|c|}
\hline Analyte & $\begin{array}{l}\text { Wistonic Tenk's } \\
\text { Content } \\
\text { Estimate }\end{array}$ & $\begin{array}{l}\text { Characteri } \\
\text { Reeul }\end{array}$ & tion & $\begin{array}{l}\text { Total } \\
\text { Tenk } \\
\text { inventory }\end{array}$ \\
\hline 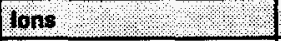 & $(\mu, d 4)$ & $60 \mathrm{H}$ & 9019 & $(k a)$ \\
\hline Ammonia $\left(\mathrm{NH}_{3}\right)$ & $1.08 E+05$ & $2.73 E+05$ & 228 & 1,140 \\
\hline Carbonate $\left(\mathrm{CO}_{3}{ }^{-}\right)$ & $1.74 E+07$ & $2.68 E+07$ & 22,300 & $1.12 E+05$ \\
\hline Chloride (Cr) & $2.16 E+06$ & $2.90 E+06$ & 2,420 & 12,100 \\
\hline Cyanide (CN') & 5,280 & 24,600 & 20.5 & 103 \\
\hline Fluoride (F) & $<61,600$ & $<1.68 \mathrm{E}+05$ & $<140$ & $<702$ \\
\hline Hydroxide $\left(\mathrm{OH}^{-}\right)$ & $7.09 E+06$ & $9.15 E+06$ & 7,630 & 38,200 \\
\hline Nitrate $\left(\mathrm{NO}_{3}{ }^{-}\right)$ & $6.03 E+07$ & $7.82 \mathrm{E}+07$ & 65,200 & $3.27 E+05$ \\
\hline Nitrite $\left(\mathrm{NO}_{2}\right)$ & $2.60 E+07$ & $3.80 E+07$ & 31,700 & $1.59 E+05$ \\
\hline Phosphate $\left(\mathrm{PO}_{4}{ }^{-1}\right)$ & $1.80 E+07$ & $1.16 E+07$ & 9,670 & 48.500 \\
\hline Sulfate $\left(\mathrm{SO}_{4}{ }^{-}\right)$ & $2.06 \mathrm{E}+06$ & $4.51 E+06$ & 3,760 & 18,900 \\
\hline Radionuclides & $(\mu \mathrm{Ci} / \mathrm{L})$ & $(\mu \mathrm{Cl} / \mathrm{L})$ & $\mu \mathrm{Ci} / \mathrm{g}$ & (Ci) \\
\hline${ }^{241} \mathrm{Am}$ & 0.534 & 0.419 & $3.49 \mathrm{E}-04$ & 1.75 \\
\hline${ }^{125} \mathrm{Sb}$ & $\cdots$ & $<431$ & $<0.359$ & $<1,800$ \\
\hline${ }^{14} \mathrm{C}$ & 0.295 & 0.499 & 4.16E-04 & 2.09 \\
\hline${ }^{144} \mathrm{Ce} / \mathrm{Pr}$ & -- & $<1,030$ & $<0.00108$ & $<4,310$ \\
\hline${ }^{134} \mathrm{Cs}$ & $<24$ & $<29.8$ & $<0.0248$ & $<125$ \\
\hline${ }^{137} \mathrm{Cs}$ & 180,000 & $2.28 \mathrm{E}+05$ & 190 & $9.53 E+05$ \\
\hline${ }^{60} \mathrm{Co}$ & $<9$ & 76.3 & 0.0636 & 319 \\
\hline${ }^{242} \mathrm{Cm}$ & 0.00112 & $\cdots$ & $9.33 \mathrm{E}-07$ & 0.00468 \\
\hline${ }^{2143} \mathrm{Cm}$ & 0.0414 & $\cdots$ & $3.45 E-05$ & 0.173 \\
\hline${ }^{244} \mathrm{Cm}$ & 0.00439 & $<0.0637$ & $<5.31 \mathrm{E}-05$ & $<0.266$ \\
\hline 129 & $<0.0750$ & $<0.0370$ & $<3.08 E-05$ & $<0.155$ \\
\hline${ }^{237} \mathrm{~Np}$ & $\cdots$ & $<1.00$ & $<8.33 E-04$ & $<4.18$ \\
\hline${ }^{94} \mathrm{Nb}$ & $<23$ & $<25.7$ & $<0.0214$ & $<107$ \\
\hline${ }^{238} \mathrm{Pu}$ & 0.0176 & $<0.163$ & $<1.36 \mathrm{E}-04$ & $<0.681$ \\
\hline${ }^{239 / 240} \mathrm{Pu}$ & 0.0333 & $<0.0748$ & $<6.23 \mathrm{E}-05$ & $<0.313$ \\
\hline${ }^{106} \mathrm{Ru} / \mathrm{Rh}$ & $<1,390$ & $<1.390$ & $<1.16$ & $<5,810$ \\
\hline${ }^{79} \mathrm{Se}$ & 0.211 & $\cdots$ & $1.76 \mathrm{E}-04$ & 0.882 \\
\hline${ }^{89 / 90} \mathrm{Sr}$ & 1,960 & 1,440 & 1.20 & 6,020 \\
\hline
\end{tabular}


Table 5-7. Tank Characterization Report Data for Double-Shell Tank 241-AP-102. (3 pages)

\begin{tabular}{|c|c|c|c|c|}
\hline Aratrte & $\begin{array}{l}\text { Historic Tank } \\
\text { Content } \\
\text { Estimate }\end{array}$ & \multicolumn{2}{|c|}{$\begin{array}{l}\text { Tank } \\
\text { Characterization } \\
\text { Result }\end{array}$} & $\begin{array}{l}\text { Total } \\
\text { Tank } \\
\text { Inventory }\end{array}$ \\
\hline Redionucides (cont) & woms & urchly & $\mu \mathrm{elg}$ & (c) \\
\hline${ }^{89} \mathrm{Tc}$ & 60.7 & 85.6 & 0.0713 & 358 \\
\hline Total aipha & 0.004 & $\cdots$ & 3.33E-06 & 0.0167 \\
\hline${ }^{3} \mathrm{H}$ & 2.6 & 13.0 & 0.00217 & 10.9 \\
\hline Organic Complexants & $(\mathrm{mg} / \mathrm{L})$ & (mg/t) & $\mu \mathrm{g} / \mathrm{g}$ & $(\mathbf{k g})$ \\
\hline Citrate & $\cdots$ & 515 & 429 & 2,15 \\
\hline EDTA & -- & 519 & 433 & 2.17 \\
\hline HEDTA & -- & 110 & 91.7 & 0.460 \\
\hline Glycolate & -- & 1,100 & 917 & 4,600 \\
\hline Oxalate & -- & 760 & 633 & 3,180 \\
\hline \multicolumn{5}{|l|}{ Physical Properties } \\
\hline Water & $77.6 \%$ & $75.0 \%$ & & N/A \\
\hline $\mathrm{pH}$ & 13.6 & 13.7 & & N/A \\
\hline Specific Gravity & $1.23 \mathrm{~g} / \mathrm{cm}^{3}$ & $1.20 \mathrm{~g} / \mathrm{cm}^{3}$ & & N/A \\
\hline TOC & $2.87 \mathrm{E}+06 \mu \mathrm{g} / \mathrm{L}$ & $3.28 \mathrm{E}+06 \mu \mathrm{g} / \mathrm{L}$ & $2,730 \mu \mathrm{g} / \mathrm{g}$ & $13,700 \mathrm{~kg}$ \\
\hline TIC & $\cdots$ & $5.35 \mathrm{E}+06 \mu \mathrm{g} / \mathrm{L}$ & $4,460 \mu \mathrm{g} / \mathrm{g}$ & $22,400 \mathrm{~kg}$ \\
\hline Organics & $(\mu \mathrm{g} / \mathrm{L})$ & $(\mu \mathrm{g} / \mathrm{L})$ & $\mu g / g$ & (kg) \\
\hline Acetone & $\cdots$ & $<500$ & $<0.417$ & $<2.09$ \\
\hline 1-Butanol & $\cdots$ & 618 & 0.515 & 2.58 \\
\hline 2-Butanone & $\cdots$ & $<500$ & $<0.417$ & $<2.09$ \\
\hline Tolvene & --- & $<500$ & $<0.417$ & $<2.09$ \\
\hline
\end{tabular}




\subsection{ANALYTICAL RESULTS INTERPRETATION}

\subsection{TANK WASTE PROFILE}

Examination of the analytical results shows that the waste in Tank 241-AP-102 is primarily an aqueous solution of inorganic salts. The most abundant constituents in the tank are sodium, nitrite, nitrate, and phosphate. The high phosphate contents is consistent with the fill history of the tank since the majority of the waste added to Tank 241-AP-102 consisted of concentrated phosphate (CP) waste from Tank 241-AP-106. The concentrated phosphate waste originated from the decontamination of Hanford's N-Reactor and contained appreciable levels of ${ }^{137} \mathrm{Cs}$ and ${ }^{90} \mathrm{Sr}$ as confirmed by the analyses of the contents of Tank 241-AP-102. Most of the organic compounds in the waste are attributed to the presence of organic complexants or their decomposition products.

\subsection{WASTE SUMMARY AND CONDITIONS}

\subsubsection{In-Tank Chemistry}

The most significant characteristic of the tank chemistry is the high dissolved solids content and the potential for precipitation upon cooling. At the temperature sampled, the tank contents will remain a homogenous, non-viscous liquid. It is unclear however, if the tank temperature of $81^{\circ} \mathrm{F}$ at sampling was due to the physical stirring of the tank contents prior to sampling, heats of solution resulting from increased mixing, radiological heating, the onset of spring weather, or simply calibration problems with the thermocouples. The amount of heat resulting from radioactivity in the tank is calculated in Table 6-1. If cooling effects are neglected, the reported value, 4,630 Watts, translates into a temperature increase in Tank 241-AP-102 of approximately $7^{\circ} \mathrm{C}$, or $13^{\circ} \mathrm{F}$, per year. Since the temperature of the tank ranges between 78 and $86^{\circ} \mathrm{F}$, it may be concluded that the elevated temperature is due to radioactive activity, however most of the heat generated throughout the year is dissipated.

\subsubsection{Regulatory Limits}

The following constituents were found at concentrations greater than the toxicity characteristic leach procedure (TCLP) thresholds (40 CFR Part 261):

\begin{tabular}{|l|c|c|}
\hline Constituent & $\begin{array}{c}\text { Concentration } \\
\text { (mg/L) }\end{array}$ & TCLP Limit (mg/L) \\
\hline Cadmium & 1.47 & 1.0 \\
\hline Chromium & 618 & 5.0 \\
\hline
\end{tabular}

In addition, the calculated $\mathrm{pH}$ of 13.7 was well above the Resource Conservation and Recovery Act pH limit of 12.5 for corrosivity; however, buffering effects were not taken into consideration. 
Table 6-1. Tank 241-AP-102 Radionuclide Inventory and Projected Heat Load.

\begin{tabular}{|l|c|c|}
\hline \multicolumn{1}{|c|}{ Radionuclide } & \multicolumn{1}{|c|}{$\mathrm{d}$} & Watts \\
\hline${ }^{241} \mathrm{Am}$ & 1.75 & 0.0574 \\
\hline${ }^{125} \mathrm{Sb}$ & $<1,800$ & $<6.01$ \\
\hline${ }^{144} \mathrm{Ce} / \mathrm{Pr}$ & $<4,310$ & $<34.5$ \\
\hline${ }^{134} \mathrm{Cs}$ & $<123$ & $<1.25$ \\
\hline${ }^{137} \mathrm{Cs}$ & $9.53 \mathrm{E}+05$ & 4.490 \\
\hline${ }^{60} \mathrm{Co}$ & 319 & 4.91 \\
\hline${ }^{242} \mathrm{Cm}$ & 0.00468 & $1.69 \mathrm{E}-04$ \\
\hline${ }^{244} \mathrm{Cm}$ & $<0.265$ & $<9.15 \mathrm{E}-03$ \\
\hline${ }^{129} \mathrm{I}$ & $<0.155$ & $<7.25 \mathrm{E}-05$ \\
\hline${ }^{237} \mathrm{~Np}$ & $<4.18$ & $<0.120$ \\
\hline${ }^{238} \mathrm{Pu}$ & $<0.681$ & $<0.0220$ \\
\hline${ }^{239 / 240} \mathrm{Pu}$ & $<0.312$ & $<0.00952$ \\
\hline${ }^{106} \mathrm{Ru} / \mathrm{Rh}$ & $<5,810$ & $<56.1$ \\
\hline${ }^{89 / 90} \mathrm{Sr}$ & 6,020 & 40.3 \\
\hline${ }^{99} \mathrm{Tc}$ & 358 & 0.179 \\
\hline \hline${ }^{\mathrm{Total}} \mathrm{Watts}$ & & $\sim 4.630$ \\
\hline
\end{tabular}

\subsection{PROGRAM ELEMENT SPECIFIC ANALYSES}

The sampling and analysis of Hanford Site waste tanks is driven by the need to satisfy the characterization requirements of the various Tank Waste Remediation System (TWRS) program elements. These characterization needs are implemented and documented through the Data Quality Objective (DQO) process, and expressed in a series of program specific DQO documents. The data needs are summarized in the TWRS Tank Waste Analysis Plan (Bell, 1994).

This Tank Characterization Report is the final step in the characterization of Tank 241 AP-102. According to the process and issue based data requirements, the inventory estimates and waste properties contained in this report can be applied to the data requirements of the various program elements. Contained in Table 6-2 is a summary of which program data needs are fulfilled through this characterization of the waste in Tank 241-AP102 , based on a review of the stated sampling and analysis requirements. In the future, the applicability of Tank Characterization Report results to each TWRS program element will be documented in tank specific Tank Characterization Plans, prior to the tank sampling. 
Table 6-2. Applicability of Characterization Information to the Data Needs of the TWRS Program Elements.

\begin{tabular}{|l|c|}
\hline \multicolumn{1}{|c|}{ Data Quality Objective } & $\begin{array}{c}\text { Applicability to Characterization } \\
\text { of Tank 241 AP-107 }\end{array}$ \\
\hline Tank Safety Screening & applies \\
\hline Ferrocyanide Safety Issues & does not apply \\
\hline Flammable Gas Tanks Crust Burn Issue & does not apply \\
\hline Generic Tank Vapor Issue Resolution & not addressed \\
\hline Flammable Gas Tank & not completed \\
\hline Waste Compatibility & applies \\
\hline Organic Fuel Rich Tank & does not apply \\
\hline Rotary Core Vapor Sampling & does not apply \\
\hline Evaporator Operations & not completed \\
\hline Process Control & not completed \\
\hline Waste Tank Retrieval & not completed \\
\hline Waste Tank Pretreatment & not completed \\
\hline High-Level Immobilization & not completed \\
\hline Low-Level Immobilization & not completed \\
\hline Solid, Low-Level Waste Disposal & not completed \\
\hline RCRA Part B Permit Application & not completed \\
\hline Tank C-106 High-Heat Safety Issue & does not apply \\
\hline Organic Layer Sampling of Tank C-103 & does not apply \\
\hline Tank C-103 Vapor and Gas Sampling & does not apply \\
\hline
\end{tabular}

'The sampling requirement for the Safety Screening Data Ouality Objective (Babad, 1994 / calls for both vertical waste samples and a vapor space sample. The sampling and analysis of Tank 241-AP-102 supports full characterization of the waste in the tank; vapor space sampling or characterization was not conducted as part of this activity.

applies - The data needs expressed in this Data Quality Objectives document are fulfilled through this characterization report.

does not apply . The data needs expressed in this Data Quality Objectives document do not apply to the waste in Tank 241-AP-107.

not addressed - The data needs expressed in this Dato Quality Objectives document were not addressed by this characterization report.

not complete - At the date of preparation of this report, this Data Quality Objectives document has not yet been completed. 
THSPAGE NTENTONALU LEFT BLANK 


\subsection{STATISTICAL INTERPRETATION}

\subsection{MASS AND CHARGE BALANCES}

The principal objective for performing a mass and charge balance is to determine if the measurements are self-consistent. In calculating the balances, only analytes detected at a concentration of $1 \mathrm{ppm}$ or greater were considered. All phosphorous in the tank was assumed to be present as phosphate; therefore, the IC phosphate value rather than the ICP phosphorous result was included in the calculations. Aluminum was theorized to exist as tetrahydroxoaluminate, $\mathrm{Al}(\mathrm{OH})_{4}{ }^{\circ}$. Table 7-1 a lists the cations and anions used in the analysis.

Even though the free hydroxide concentration of Tank 241-AP-102 was measured by the laboratory, it was treated as an unknown during this exercise. Since a calculated charge imbalance resulted in the absence of hydroxide, a theoretical hydroxide value was determined by utilizing the ion to correct for the deficient negative charge. The mass of hydroxide was then predicted from the derived charge.

Mass and charge balance results are reported in Table 7-1b. The mass concentration, $\mu \mathrm{g} / \mathrm{g}$, resulting from the sum of the cations, anions, and hydroxide was subtracted from a million in order to obtain an estimated value for the weight percent of water. In other words, mass not accountable to the analyte concentrations is attributed to water. Inspection of Table $7-1 \mathrm{~b}$ demonstrates that the predicted values for hydroxide and water agree to within $\pm 5 \%$ of the recorded Tank Characterization Report results which were derived from the analytical data.

\subsection{HOMOGENIZATION TESTS}

This discussion of homogeneity in Tank 241-AP-102, along with the supporting tables, were taken from Welsh (1993).

The characterization test plan requested that the homogeneity of the waste within Tank 241-AP-102 be determined based on the analytical results of $\mathrm{Na},{ }^{137} \mathrm{Cs}$, and $\mathrm{PO}_{4}{ }^{3}$. Differences between the analytical results at the 15 locations sampled within Tank 241-AP102 were used to address this request. The composite analytical results are included as a sixteenth location for the statistical analysis and random analytical error estimate calculation.

An analysis of variance (ANOVA) was calculated on the sample results using the structure in the model described later in section B.1 of Appendix B. The ANOVA table contains a test that determines if the variability between locations $\left(\sigma_{L}{ }^{2}\right)$ is significantly greater than zero. If the test indicates that $\sigma_{\mathrm{L}}{ }^{2}$ is significantly greater than zero, then it is concluded that the tank is not homogenous with respect to that analyte. If the test indicates that $\sigma_{L}{ }^{2}$ is not significantly different from zero, then it is concluded that the tank is homogenous with respect to that analyte. These tests, one for each analyte $\left(\mathrm{Na},{ }^{137} \mathrm{Cs}\right.$, and $\left.\mathrm{PO}_{4}{ }^{3-}\right)$ were conducted at the 0.05 level of significance. The p-values from the statistical tests were 0.7952 for $\mathrm{Na}, 0.5178$ for ${ }^{137} \mathrm{Cs}$, and 0.2447 for $\mathrm{PO}_{4}{ }^{3-}$; if the p-value was less than 0.05 then $\sigma_{\mathrm{L}}{ }^{2}$ is significantly different than zero. 
Table 7-1a. Mass and Charge Balance.

\begin{tabular}{|c|c|c|}
\hline \& & Mass $\mu g / g$ & Charge $\mu \mathrm{mol} / \mathrm{g}$ \\
\hline \multicolumn{3}{|l|}{ Cations } \\
\hline Antimony & 5.51 & 0.226 \\
\hline Cadmium & 1.23 & 0.022 \\
\hline Calcium & 66.7 & 3.34 \\
\hline Chromium & 515 & 19.8 \\
\hline Iron & 3.18 & 0.171 \\
\hline Magnesium & 2.19 & 0.180 \\
\hline Potassium & 1,080 & 27.6 \\
\hline Sodium & 85,000 & 3,700 \\
\hline Uranium & 3.85 & 0.970 \\
\hline \multicolumn{3}{|l|}{ Anions } \\
\hline Chloride & 2,420 & 68.3 \\
\hline Cyanide & 20.5 & 0.788 \\
\hline Nitrate & 65,200 & 1,052 \\
\hline Nitrite & 31,700 & 689 \\
\hline Phosphate & 9,670 & 305 \\
\hline Sulfate & 3,760 & 78.3 \\
\hline Carbonate (TIC) & 22,300 & 743 \\
\hline Tetrahydroxoaluminate $\mathrm{Al}(\mathrm{OH})_{4}^{-}$ & 34,000 & 358 \\
\hline
\end{tabular}

Table 7-1b. Mass and Charge Balance Totals

\begin{tabular}{|l|c|c|}
\hline Totals & 86,700 & +3752 \\
\hline Cations & 169,000 & -3294 \\
\hline Anions & 7,790 & -458 \\
\hline Predicted Hydroxide from Charge Balance & 737,000 & \\
\hline Predicted Water from Mass Balance & 7,630 & \\
\hline Hydroxide (TCR result) & 750,000 & \\
\hline Water (TCR result) & & \\
\hline
\end{tabular}


The $\mathrm{Na}^{137} \mathrm{Cs}$, and $\mathrm{PO}_{4}{ }^{3 .}$ data are contained in Tables 7-2, 7-3, and 7-4 respectively. For all three analytes the ANOVA indicated that $\sigma_{\mathrm{L}}{ }^{2}$ is not significantly different from zero. Therefore, based on the $\mathrm{Na},{ }^{137} \mathrm{Cs}$, and $\mathrm{PO}_{4}{ }^{3-}$ analytical results, the contents of Tank $241-\mathrm{AP}$ 102 are considered to be homogenous.

The ANOVA was calculated using the sample results for the remaining analytes that were reported with "real" numbers (no "less than" values). The ANOVA indicated that $\sigma_{L}{ }^{2}$ is not significantly different from zero at the 0.05 level of significance for $\mathrm{Al}, \mathrm{Ba}, \mathrm{Cd}, \mathrm{Cr}, \mathrm{Fe}$, $\mathrm{Ni}, \mathrm{K}, \mathrm{P}, \mathrm{Cl}, \mathrm{NO}_{2}{ }^{\circ}, \mathrm{NO}_{3}{ }^{\circ}, \mathrm{SO}_{4}{ }^{2-}$, TOC, percent water, $\mathrm{OH}^{-},{ }^{90} \mathrm{Sr},{ }^{14} \mathrm{C},{ }^{99} \mathrm{Tc}^{241} \mathrm{Am}, \mathrm{Se}, \mathrm{HEDTA}$, EDTA, and Citrate. The ANOVA indicated that $\sigma_{\mathrm{L}}{ }^{2}$ is significantly different from zero for $\mathrm{Be}$ and TIC.

\subsection{ANALYTICAL ERROR ESTIMATION}

Analytical error consists of two parts, random and systematic. Table 7-5 outlines both the analytical and systematic error estimates with actual data, organized by analyte (Welsh, 1993). Error estimates were not done for analytes with "less than" (non-detected) values.

\section{Random Analytical Error}

The estimate of the randorn analytical error for each analyte can be determined from the analytical results from the duplicate samples, from the analysis of standards. However, the analysis of standards does not account for all sources of variability, such as matrix interferences.

The duplicate sample results were analyzed to determine if any had a relative percent difference (RPD) or relative standard deviation (RSD) value exceeding the criterion of three times the random analytical error from sample results of the analyte values listed in the first data column of Table 7-5. Barium has three duplicate samples with an RPD or RSD over the criterion and beryllium, cadmium, iron, nickel, hydroxide, EDTA, and HEDTA each had one duplicate pair over the criterion. The problem with barium was due to the sample concentration being near the detection limit. Detection limit proximity also resulted in the high RSD for uranium, although none of the sample duplicates exceeded the criterion. When the single sample pair over the criterion were deleted from the analysis for iron and TIC, the RSDs became $\$ 6.5$ and 3.8 , respectively (Table $7-5)$.

An extremely large error estimate, $76 \%$, was calculated for the sample results of ${ }^{3} \mathrm{H}$. This can be attributed to problems in the analytical methodology. Distillation techniques used to recover tritiated water vapor from samples (tritium must be in the form of tritiated water) did not perform well. Therefore, the ${ }^{3} \mathrm{H}$ results are questionable and may exhibit a low bias.

A statistical analysis of glycolate was not performed since all of the data were the same value. For the organic constituents, it was not possible to calculate measurement error estimates from standard results since the High Performance Liquid Chromatography (HPLC) and Ion Chromatography $(\mathrm{IC}$ methods utilized to analyze them are relatively new procedures currently under development. 
Table 7-2. Na Data. (Welsh, 1993)

\begin{tabular}{|c|c|c|c|c|c|}
\hline $\begin{array}{l}\text { Sample } \\
\text { Number }\end{array}$ & Position & $\begin{array}{l}\text { Naygh } \\
\text { Result } 1\end{array}$ & $\begin{array}{l}\text { Ne poil } \\
\text { Result } 2\end{array}$ & $\begin{array}{l}\text { Napgoh } \\
\text { mean }\end{array}$ & FPD \\
\hline $\begin{array}{l}\text { G342 } \\
\text { G449 } \\
\text { G450 } \\
\text { G348 } \\
\text { G352 } \\
\text { G349 } \\
\end{array}$ & $\begin{array}{l}1 \\
2 \\
3 \\
4 \\
5 A \\
5 B\end{array}$ & $\begin{array}{l}1.00 E+08 \\
1.02 E+08 \\
1.04 E+08 \\
1.03 E+08 \\
1.02 E+08 \\
1.06 E+08 \\
\end{array}$ & $\begin{array}{l}1.00 E+08 \\
1.01 E+08 \\
1.04 E+08 \\
1.02 E+08 \\
1.01 E+08 \\
1.02 E+08\end{array}$ & $\begin{array}{l}1.00 E+08 \\
1.01 E+08 \\
1.04 E+08 \\
1.03 E+08 \\
1.01 E+08 \\
1.04 E+08\end{array}$ & $\begin{array}{l}0.1 \\
0.9 \\
0.3 \\
1.0 \\
0.2 \\
3.6 \\
\end{array}$ \\
\hline $\begin{array}{l}\text { G453 } \\
\text { G358 } \\
\text { G353 } \\
\text { G454 } \\
\text { G359 } \\
\text { G363 }\end{array}$ & $\begin{array}{l}6 \\
7 A \\
7 B \\
8 \\
9 \\
10 \\
\end{array}$ & $\begin{array}{l}1.02 E+08 \\
1.03 E+08 \\
1.00 E+08 \\
1.03 E+08 \\
9.91 E+07 \\
1.01 E+08\end{array}$ & $\begin{array}{l}1.05 E+08 \\
9.98 E+07 \\
1.01 E+08 \\
1.03 E+08 \\
9.80 E+07 \\
9.99 E+07\end{array}$ & $\begin{array}{l}1.04 E+08 \\
1.01 E+08 \\
1.00 E+08 \\
1.03 E+08 \\
9.58 E+07 \\
1.00 E+08\end{array}$ & $\begin{array}{l}2.7 \\
4.2 \\
0.8 \\
0.6 \\
1.1 \\
0.7\end{array}$ \\
\hline $\begin{array}{l}\text { G364 } \\
\text { G333 } \\
\text { G459 } \\
\text { G460 } \\
\text { G338 } \\
\text { G341 }\end{array}$ & $\begin{array}{l}11 \\
12 \\
13 \mathrm{~A} \\
13 \mathrm{~B} \\
14 \\
15 \\
\end{array}$ & $\begin{array}{l}1.03 E+08 \\
9.97 E+07 \\
1.02 E+08 \\
1.02 E+08 \\
1.03 E+08 \\
1.01 E+08\end{array}$ & $\begin{array}{l}1.00 E+08 \\
1.00 E+08 \\
1.02 E+08 \\
1.00 E+08 \\
1.03 E+08 \\
1.01 E+08 \\
\end{array}$ & $\begin{array}{l}1.03 E+08 \\
1.00 E+08 \\
1.03 E+08 \\
1.01 E+08 \\
1.03 E+08 \\
1.01 E+08\end{array}$ & $\begin{array}{l}2.4 \\
0.5 \\
0.7 \\
1.3 \\
0.3 \\
0.3 \\
\end{array}$ \\
\hline $\begin{array}{c}\mathrm{G} 443 \\
\mathrm{G} 470^{*}\end{array}$ & $\begin{array}{l}\text { COMP } \\
\text { COMP }\end{array}$ & $\begin{array}{l}1.02 E+08 \\
1.06 E+08\end{array}$ & $\begin{array}{l}1.02 E+08 \\
1.05 E+08\end{array}$ & $\begin{array}{l}1.02 E+08 \\
1.05 E+08\end{array}$ & $\begin{array}{l}0.2 \\
0.8\end{array}$ \\
\hline
\end{tabular}


Table 7-3. ${ }^{137}$ Cs Data. (Welsh, 1993).

\begin{tabular}{|c|c|c|c|c|c|c|}
\hline $\begin{array}{l}\text { Sample } \\
\text { Humber }\end{array}$ & postiton & $\begin{array}{l}197 \mathrm{Cs} \\
\text { pournt } \\
\text { pesult } 1\end{array}$ & $\begin{array}{c}{ }^{137} \mathrm{Cs} \mu \mathrm{Cl} / \mathrm{mL} \\
\text { Result } 2\end{array}$ & ${ }^{137} \mathrm{Cs} \mathrm{rCl} / \mathrm{mL}$ & $\begin{array}{l}{ }^{37} \mathrm{Gs} \\
\text { Standard } \\
\text { Bovition }\end{array}$ & $\begin{array}{l}\text { RPD or } \\
\text { RSD }\end{array}$ \\
\hline $\begin{array}{c}\text { G342 } \\
\text { G449 } \\
\text { G450 } \\
\text { G477* } \\
\text { G348 } \\
\text { G352 } \\
\text { G349 }\end{array}$ & $\begin{array}{l}1 \\
2 \\
3 \\
3 \\
4 \\
5 \mathrm{~A} \\
5 \mathrm{~B} \\
\end{array}$ & $\begin{array}{l}2.32 E+02 \\
2.30 E+02 \\
2.29 E+02 \\
2.20 E+02 \\
2.32 E+02 \\
2.25 E+02 \\
2.36 E+02 \\
\end{array}$ & $\begin{array}{l}2.35 E+02 \\
2.30 E+02 \\
2.35 E+02 \\
2.22 E+02 \\
2.17 E+02 . \\
2.25 E+02 \\
2.38 E+02 \\
\end{array}$ & $\begin{array}{l}2.335 E+02 \\
2.300 E+02 \\
2.320 E+02 \\
2.210 E+02 \\
2.245 E+02 \\
2.250 E+02 \\
2.370 E+02\end{array}$ & : & $\begin{array}{l}1.3 \\
0.0 \\
2.6 \\
0.9 \\
6.7 \\
0.0 \\
0.8 \\
\end{array}$ \\
\hline G453 & 6 & $2.33 E+02$ & $2.33 E+02$ & $2.330 E+02$ & $\therefore$ & 0.0 \\
\hline $\begin{array}{l}\text { G358 } \\
\text { G358 }\end{array}$ & $\begin{array}{l}\text { 7A } \\
\text { 7A RR }\end{array}$ & $\begin{array}{l}2.15 E+02 \\
2.17 E+02\end{array}$ & $\begin{array}{l}2.16 E+02 \\
2.23 E+02\end{array}$ & $2.178 E+02$ & 3.6 & 1.7 \\
\hline $\begin{array}{l}\text { G353 } \\
\text { G353 }\end{array}$ & $\begin{array}{l}7 B \\
7 B ~ R R\end{array}$ & $\begin{array}{l}2.28 E+02 \\
2.22 E+02\end{array}$ & $\begin{array}{l}2.28 E+02 \\
2.24 E+02\end{array}$ & $2.255 E+02$ & 3.0 & 1.3 \\
\hline $\begin{array}{c}\text { G454 } \\
\text { G471* } \\
\text { G359 } \\
\text { G363 }\end{array}$ & $\begin{array}{l}8 \\
8 \\
9 \\
10 \\
\end{array}$ & $\begin{array}{l}2.29 E+02 \\
2.15 E+02 \\
2.25 E+02 \\
2.37 E+02 \\
\end{array}$ & $\begin{array}{l}2.28 E+02 \\
2.10 E+02 \\
2.25 E+02 \\
2.35 E+02 \\
\end{array}$ & $\begin{array}{l}2.285 E+02 \\
2.125 E+02 \\
2.250 E+02 \\
2.360 E+02\end{array}$ & $\begin{array}{l}- \\
- \\
-\end{array}$ & $\begin{array}{l}0.4 \\
2.4 \\
0.0 \\
0.8\end{array}$ \\
\hline $\begin{array}{l}\text { G364 } \\
\text { G333 } \\
\text { G459 } \\
\text { G460 } \\
\text { G338 } \\
\text { G341 } \\
\text { G476* }\end{array}$ & $\begin{array}{l}11 \\
12 \\
13 A \\
13 B \\
14 \\
15 \\
15\end{array}$ & $\begin{array}{l}2.25 E+02 \\
2.25 E+02 \\
2.15 E+02 \\
2.12 E+02 \\
2.26 E+02 \\
2.34 E+02 \\
2.24 E+02 \\
\end{array}$ & $\begin{array}{l}2.22 \mathrm{E}+02 \\
2.24 \mathrm{E}+02 \\
2.19 \mathrm{E}+02 \\
2.16 \mathrm{E}+02 \\
2.27 \mathrm{E}+02 \\
2.36 \mathrm{E}+02 \\
2.25 \mathrm{E}+02 \\
\end{array}$ & $\begin{array}{l}2.235 E+02 \\
2.245 E+02 \\
2.170 E+02 \\
2.140 E+02 \\
2.265 E+02 \\
2.350 E+02 \\
2.245 E+02 \\
\end{array}$ & $\begin{array}{l}- \\
- \\
- \\
- \\
- \\
-\end{array}$ & $\begin{array}{l}1.3 \\
0.4 \\
1.8 \\
1.9 \\
0.4 \\
0.9 \\
0.4 \\
\end{array}$ \\
\hline $\begin{array}{l}\text { G443 } \\
\text { G443 }\end{array}$ & $\begin{array}{l}\text { COMP } \\
\text { COMP RR }\end{array}$ & $\begin{array}{l}2.41 E+02 \\
2.03 E+02\end{array}$ & $\begin{array}{l}2.42 E+02 \\
2.08 E+02\end{array}$ & $2.235 E+O 2$ & 20.9 & 9.3 \\
\hline G470* & COMP & $2.15 E+02$ & $2.17 E+02$ & $2.160 E+02$ & - & 0.9 \\
\hline
\end{tabular}

": Heated sample.

RR: Re-run. 
Table 7-4. $\mathrm{PO}_{4}^{-3}$ Data. (Welsh, 1993).

\begin{tabular}{|c|c|c|c|c|c|c|}
\hline $\begin{array}{l}\text { Sanpie } \\
\text { flumbor }\end{array}$ & Position & $\begin{array}{l}137 \mathrm{Cs} \\
\text { Poiml } \\
\text { Result } 1\end{array}$ & $\begin{array}{l}{ }^{137} \mathrm{Cs} \\
\text { pol/mL } \\
\text { Result 2 }\end{array}$ & $\begin{array}{l}13 \mathrm{Cs} \\
\mathrm{mol}_{\mathrm{m} \mathrm{mL}}\end{array}$ & $\begin{array}{l}137 \mathrm{Gs}_{\mathrm{s}} \\
\text { standard } \\
\text { Dovtation }\end{array}$ & $\begin{array}{l}\text { nPD or } \\
\text { nSD }\end{array}$ \\
\hline $\begin{array}{l}\text { G509 } \\
\text { G523* }\end{array}$ & $\begin{array}{l}1 \\
2\end{array}$ & $\begin{array}{l}1.19 E+04 \\
1.16 E+04\end{array}$ & $\begin{array}{l}1.22 E+04 \\
1.15 E+04\end{array}$ & $\begin{array}{l}1.205 E+04 \\
1.155 E+04\end{array}$ & - & $\begin{array}{l}2.5 \\
0.9\end{array}$ \\
\hline $\begin{array}{l}\text { G477* } \\
\text { G477* }\end{array}$ & 3 RR & $\begin{array}{l}1.14 E+04 \\
1.06 E+04\end{array}$ & $\begin{array}{l}1.29 E+04 \\
1.07 E+04\end{array}$ & $1.140 E+04$ & $1.061 E+03$ & 9.5 \\
\hline $\begin{array}{l}\text { G510* } \\
\text { G521* } \\
\text { G511* }\end{array}$ & $\begin{array}{l}4 \\
5 A \\
5 B\end{array}$ & $\begin{array}{l}1.07 E+04 \\
1.23 E+04 \\
1.13 E+04\end{array}$ & $\begin{array}{l}1.18 E+04 \\
1.20 E+04 \\
1.11 E+04\end{array}$ & $\begin{array}{l}1.125 E+04 \\
1.215 E+04 \\
1.205 E+04\end{array}$ & - & $\begin{array}{l}9.8 \\
2.5 \\
1.8 \\
\end{array}$ \\
\hline $\begin{array}{l}\text { G527* } \\
\text { G527* }\end{array}$ & $\begin{array}{l}6 \\
6 R R\end{array}$ & $\begin{array}{l}1.24 E+04 \\
8.09 E+04\end{array}$ & $\begin{array}{l}1.02 E+04 \\
8.27 E+04\end{array}$ & $9.740 E+03$ & $2.014 E+03$ & 20.7 \\
\hline $\begin{array}{l}\text { G515* } \\
\text { G522* } \\
\text { G471* }\end{array}$ & $\begin{array}{l}7 A \\
7 B \\
8\end{array}$ & $\begin{array}{l}1.15 E+04 \\
1.24 E+04 \\
1.28 E+04\end{array}$ & $\begin{array}{l}1.23 E+04 \\
1.24 E+04 \\
1.19 E+04\end{array}$ & $\begin{array}{l}1.190 E+04 \\
1.240 E+04 \\
1.235 E+04\end{array}$ & - & $\begin{array}{l}6.7 \\
0.0 \\
7.3\end{array}$ \\
\hline $\begin{array}{l}\text { G516* } \\
\text { G516* }\end{array}$ & $\begin{array}{l}9 \\
9 \mathrm{RR}\end{array}$ & $\begin{array}{l}1.03 E+04 \\
1.21 E+04\end{array}$ & $\begin{array}{l}1.03 E+04 \\
1.21 E+04\end{array}$ & $1.160 E+04$ & $8.680 E+02$ & 7.5 \\
\hline G533* & 10 & $1.22 E+04$ & $1.22 E+04$ & 1.220E + 04 & - & 0.0 \\
\hline $\begin{array}{l}\text { G534* } \\
\text { G528* } \\
\text { G517* } \\
\text { G536* } \\
\text { G528* } \\
\text { G476* }\end{array}$ & $\begin{array}{l}11 \\
12 \\
13 \mathrm{~A} \\
13 \mathrm{~B} \\
14 \\
15 \\
\end{array}$ & $\begin{array}{l}1.20 E+04 \\
1.05 E+04 \\
1.14 E+04 \\
1.18 E+04 \\
1.13 E+04 \\
1.28 E+04\end{array}$ & $\begin{array}{l}1.20 E+04 \\
1.05 E+04 \\
1.14 E+04 \\
1.18 E+04 \\
1.13 E+04 \\
1.28 E+04 \\
\end{array}$ & $\begin{array}{l}1.190 E+04 \\
1.075 E+04 \\
1.150 E+04 \\
1.185 E+04 \\
1.130 E+04 \\
1.235 E+04\end{array}$ & $\begin{array}{l}- \\
- \\
- \\
-\end{array}$ & $\begin{array}{l}1.7 \\
4.7 \\
1.7 \\
0.8 \\
0.0 \\
7.3\end{array}$ \\
\hline G470* & COMP & $1.29 E+04$ & $1.29 E+04$ & $1.330 E+04$ & - & 6.0 \\
\hline
\end{tabular}

*: Heated sample.

RR: Re-run.

\section{Systematic Analytical Error}

The estimate of the systematic error is determined from the analysis of standards or spike recoveries. The third and fourth columns of Table 7-5 list the systematic analytical error estimates for each analyte (Welsh, 1993). Spike precision was good for all analytes except citrate, in which both spikes were outside the specified limits of $100 \pm 25 \%$. 
Table 7-5. Measurement Error Estimates (Welsh, 1993). (2 pages)

\begin{tabular}{|c|c|c|c|c|}
\hline \multirow{2}{*}{ Analyte } & \multicolumn{2}{|c|}{$\begin{array}{c}\text { Random andiytical orror } \\
\text { estimate } \\
1 \text { RSD }(\%)\end{array}$} & \multicolumn{2}{|c|}{$\begin{array}{l}\text { Systematic orror } \\
\text { estimate } \\
1 \text { RSD }(\%)\end{array}$} \\
\hline & $\begin{array}{c}\text { From eample } \\
\text { restht }\end{array}$ & Hom tondard & $\begin{array}{l}\text { From standard } \\
\text { resthe }\end{array}$ & Pom poiks \\
\hline Al & 1.2 & 4.6 & 4.7 & 1.3 \\
\hline $\mathrm{Ba}$ & 16.1 & 2.1 & 2.4 & 2.9 \\
\hline $\mathrm{Be}$ & 6.6 & 3.7 & 0.8 & 4.8 \\
\hline $\mathrm{Cd}$ & 6.7 & 3.4 & 2.4 & 5.4 \\
\hline $\mathrm{Cr}$ & 1.8 & 3.4 & 1.3 & 5.5 \\
\hline $\begin{array}{l}\mathrm{Fe} \\
\mathrm{Fe}\end{array}$ & $\begin{array}{l}37.1 \\
16.5 \\
\end{array}$ & $\begin{array}{l}2.3 \\
2.3 \\
\end{array}$ & $\begin{array}{l}2.2 \\
2.2\end{array}$ & $\begin{array}{l}3.7 \\
3.7\end{array}$ \\
\hline $\mathrm{Ni}$ & 2.1 & 3.0 & 0.4 & 3.6 \\
\hline$K$ & 1.8 & 3.8 & 2.6 & 2.7 \\
\hline $\mathrm{Na}$ & 2.3 & 2.2 & 2.4 & NA" \\
\hline $\mathbf{P}$ & 2.7 & 3.7 & 4.4 & NA \\
\hline $\mathrm{Cl}$ & 5.6 & 4.6 & 0.8 & 2.9 \\
\hline $\mathrm{NO}_{2}^{-}$ & 5.8 & 3.8 & 0.4 & 2.6 \\
\hline $\mathrm{NO}_{3}^{\circ}$ & 5.7 & 4.6 & 2.8 & 5.6 \\
\hline $\mathrm{PO}_{4}^{3 \cdot}$ & 7.5 & 4.0 & 1.5 & 8.0 \\
\hline $\mathrm{SO}_{4}{ }^{2-}$ & 5.8 & 3.7 & 2.7 & 9.0 \\
\hline SpG & 0.2 & 0.6 & 1.1 & NA \\
\hline TIC & 3.9 & 3.5 & 3.2 & 2.6 \\
\hline $\begin{array}{l}\text { TOC } \\
\text { TOC \# }\end{array}$ & $\begin{array}{r}14.6 \\
3.8\end{array}$ & $\begin{array}{l}3.0 \\
3.0\end{array}$ & $\begin{array}{l}4.7 \\
4.7 \\
\end{array}$ & $\begin{array}{l}2.7 \\
2.7 \\
\end{array}$ \\
\hline$\%$ Water & 0.3 & 1.2 & 1.4 & NA \\
\hline $\mathrm{OH}^{-}$ & 1.7 & 2.0 & 0.2 & NA \\
\hline${ }^{137} \mathrm{Cs}$ & 3.4 & 5.1 & 6.3 & NA \\
\hline${ }^{90} \mathrm{Sr}$ & 6.9 & 8.1 & 3.6 & NA \\
\hline${ }^{14} \mathrm{C}$ & 15.3 & 3.7 & 10.5 & 6.1 \\
\hline${ }^{99} \mathrm{Tc}$ & 5.5 & 8.6 & 9.4 & 4.9 \\
\hline${ }^{241} \mathrm{Am}$ & 23.9 & 13.6 & 4.8 & NA \\
\hline $\mathrm{Se}$ & 4.5 & 7.7 & 5.1 & 7.0 \\
\hline $\mathrm{CN}^{-}$ & 1.3 & 2.3 & 5.5 & 7.2 \\
\hline U & 42.0 & 7.3 & 4.1 & 1.9 \\
\hline
\end{tabular}


Table 7-5. Measurement Error Estimates (Welsh, 1993).

(2 pages)

\begin{tabular}{|c|c|c|c|c|}
\hline \multirow[t]{2}{*}{ Analyte } & \multicolumn{2}{|c|}{$\begin{array}{c}\text { Random anatytical error } \\
\text { estimate } \\
\text { I RSD (\%) }\end{array}$} & \multicolumn{2}{|c|}{$\begin{array}{l}\text { Syatematic enor } \\
\text { estimate } \\
1 \text { RSD }(\%)\end{array}$} \\
\hline & $\begin{array}{l}\text { From sample } \\
\text { results }\end{array}$ & $\begin{array}{c}\text { From standard } \\
\text { roults }\end{array}$ & From standard & $\begin{array}{l}\text { From spike } \\
\text { entyes }\end{array}$ \\
\hline $\mathrm{NH}_{3} / \mathrm{NH}_{4}{ }^{+}$ & 4.2 & 7.5 & 3.7 & 7.6 \\
\hline${ }^{3} \mathrm{H}$ & 76 & 5.2 & 4.8 & $* * *$ \\
\hline HEDTA & 45.7 & NA & NA & 11 \\
\hline EDTA & 27.9 & NA & NA & 10 \\
\hline Citrate & 11.8 & NA & NA & 33 \\
\hline Glycolate & NA & NA & NA & 20 \\
\hline Oxalate & 6.8 & NA & NA & 0 \\
\hline
\end{tabular}

*: Excluded results from position 7A.

\#: Excluded results from position 10.

\&: Calculated from the Laboratory Measurement Control System standards analyzed in conjunction with the samples.

**: Analyses not performed. 


\subsection{CONCLUSIONS AND RECOMMENDATIONS}

\subsection{SAFETY ISSUES}

Characterization of Double-Shell Tank 241-AP-102 supports the designation of the tank as non-Watch List. Given the current tank inventory of fissionable radionuclides, organic, and exothermic waste constituents, no credible potential exists for loss of tank integrity or release of radioactivity due to in-tank processes. Tank 241-AP-102 is within established operating safety requirements as defined by applicable Data Quality Objectives.

Tank 241-AP-102 is considered sound and non-leaking (Hanion, 1994), and examination of the waste volume history supports this conclusion (Koreski, 1994). Thermocouple data indicate that while tank temperatures are elevated above ambient soil temperatures, there is no credible risk of self-boiling or excessive heating of the current tank contents. Given the present tank integrity and waste properties, the continued active operation of Tank 241-AP-102 for waste management and storage functions poses no unreasonable risk to personnel, the public, or the environment.

\subsection{FURTHER CHARACTERIZATION NEEDS}

Characterization of the liquid contents of Tank 241 -AP-102 has been performed in this report. Further sampling and analysis of the contents of Tank 241-AP-102 is suggested for the following waste properties:

- Analysis of the tank vapor space would allow final resolution of any safety concerns regarding the presence of flammable or noxious vapors in the vapor phase.

- Characterization of the physical properties of the waste prior to retrieval or transfer operations is necessary to resolve potential waste property uncertainties. Specifically, precipitation studies should be performed to ensure that solids formation does not interfere with retrieval operations. In addition, $X$-Ray Diffractometry can be employed to determine the species present in the tank waste. Rheological analyses also need to be conducted. 
THISPAGE NTENTIONALIVLET BLANK 


\subsection{REFERENCES}

Anderson, J. D., 1992. A History of the 200 Area Tank Farms, WHC-MR-0132, Westinghouse Hanford Company, Richland, WA.

Babad, H., 1994. Tank Safety Screening Data Quality Objective, WHC-SD-WM-SP-004, Westinghouse Hanford Company, Richland, WA.

Bell, K. E., 1993. Tank Waste Remediation System Tank Waste Characterization Plan, WHCSD-WM-PLN-047, Rev. 1, Westinghouse Hanford Company, Richland, WA.

Conway, J.T., 1993. DNFSB Recommendation 93-5 to the Secretary of Energy, (letter 9400070 to H.R. O'Leary, DOE, July 19) Defense Nuclear Facilities Safety Board, Washington, D.C.

Crowe, R. D., M. Kummerer, and A. L. Postma, 1993. Estimation of Heat Load in Waste Tanks Using Average Vapor Space Temperatures, WHC-EP-0709, Westinghouse Hanford Company, Richland, WA.

De Lorenzo, D.S., J.H. Rutherford, D.J. Smith, D.B. Hiller, K.W. Johnson, 1994. Tank Characterization Reference Guide, WHC-SD-WM-TI-648, Los Alamos Technical Associates, Inc., Richland, WA.

Duchsherer, M.J., 1993. 222-S Laboratory Grout Facility Characterization Project, Tank 102AP - Data Package and Validation Summaries, WHC-SD-WM-DP-046, Rev. O, Westinghouse Hanford Company, Richland, WA.

Ecology, EPA, and DOE, 1993. Hanford Federal Facility Agreement and Consent Order, Washington State Department of Ecology, United States Environmental Protection Agency, and the United States Department of Energy, Olympia, WA.

Freeze, R. A., J. A. Cherry, 1979. Groundwater, "Groundwater and Thermal Processes", Prentice-Hall, Inc., Englewood Cliffs, N.J.

Haigh, P. G., 1992. 242-A Evaporator Sample Schedule, FSS-T-630-00001 Rev. A-0, Westinghouse Hanford Company, Richland, WA.

Halgren, D. L., 1991. Double-Shell Tank Waste Analysis Plan, WHC-SD-WM-EV-053 Rev. 1, Westinghouse Hanford Company, Richland, WA.

Hanlon, B. M., 1994. Tank Farm Surveillance and Waste Status Summary Report for November 1993, WHC-EP-0182-68, Westinghouse Hanford Company, Richland, WA.

Hendrickson, D. W., T. L. Welsh, D.M. Nguyen, 1993. Hanford Grout Disposal Program Campaign 102 Characterization and Test Plan, WHC-SD-WM-TP-136. Rev. 0 , Westinghouse Hanford Company, Richland, WA. 
Huckaby, J. L., 1992. Characterization of Vapors in Single-Shell Tanks Scheduled for RotaryMode Sampling, WHC-SD-WM-TI-536, Westinghouse Hanford Company, Richland, WA.

Husa, E. I., R. E. Raymond, R. K. Welty, S. M. Griffith, B. M. Hanlon, R. R. Rios, N. J. Vermeulen, 1993. Hanford Site Waste Storage Tank Information Notebook, WHC-EP. 0625, Westinghouse Hanford Company, Richland, WA.

Jungfleisch, F. M., 1984. TRAC: Preliminary Estimation of the Waste Inventories in Hanford Tanks Through 1980, SD-WM-TI-057, Rockwell Hanford Operations, Richland, WA.

Koontz, R. L., 1986. Double-Shell Tank Farm Facility Safety Analysis Report, SD-WM-SAR016, Westinghouse Hanford Company, Richland, WA.

Koreski, G. M., 1994. Waste Volume Projections, Westinghouse Hanford Company, Richland, WA.

Lide, D. R., Editor-in-Chief, 1992. Handbook of Chemistry and Physics, Chemical Rubber Company, Boca Raton.

Loll, C. M., 1993. 242-A Evaporator, Waste Analysis Plan, WHC-SD-WM-EV-060, Westinghouse Hanford Company, Richland, WA.

Osborne, J. W., 1992. Program Plan for the Resolution of Tank Vapor/ssues, WHC-EP-0562, Westinghouse Hanford Company, Richland, WA.

Rios, R. R., 1994. Computer Automated Surveillance System, Westinghouse Hanford Company, Richland, WA.

Wagner, R. N., 1992. Hanford Waste Vitrification Plant Feed Characterization Requirements, WHC-SD-HWV-001 Rev. 4, Westinghouse Hanford Company, Richland, WA.

Welsh, T. L. 1993. Tank 241-AP-102 Characterization and Grout Product Test Results, WHCSD-WM-TRP-168, Rev. 0, Westinghouse Hanford Company, Richland, WA.

Winters, W. I., L. Jensen, L. M. Sasaki, R. L. Weiss, J. F. Keller, A. J. Schmidt, and M. G. Woodruff, 1990. Waste Characterization Plan for Hanford Site Single-Shell Tanks, WHC-EP-0210, Westinghouse Hanford Company, Richland, WA. 
WHC-SD-WM-ER-358 REV O

Appendix A. Analytical Results Presentation 
THISPAGE NTENIONALY LET BLANK 


\section{Appendix A. Analytical Results Presentation}

\section{A.1 Introduction}

Appendix A presents the chemical and radiological characteristics of Tank 241-AP-102 in a tabular form, in terms of the specific concentrations of anions, metals, radionuclides, organic complexants, physical properties, and volatile and semivolatile organic compounds.

The data table for each analyte lists laboratory sample identification, analytical result, standard deviation, range of results, an evaluated data result, and a projected tank inventory for the particular analyte. The projected tank inventory column is not applicable for the specific gravity and percent water data. The data are listed in standard notation for values $>.001$ and $<100,000$; values outside these limits are listed in scientific notation.

\section{A.2 Table Description}

A.2.1 Abbreviations - Standard abbreviations are used to describe analytical methods.

Metals: ICP - Inductively Coupled Plasma (generic for all metals unless otherwise known)

GFAA - Graphite Furnace Atomic Absorption

GHAA - Gaseous Hydride Atomic Absorption

CVAA - Cold Vapor Atomic Absorption

FAA - Flame Atomic Absorption

lons: $\quad \mathrm{COL}$ - Colorometric Spectrophotometry

COUL - Coulorometric Titration

DT - Distillation and Titration

IC - Ion Chromatograph

ISE - Ion Selective Electrode

Radio-

nuclides

GEA - Gamma Energy Analysis

AEA - Alpha Energy Analysis

APC - Alpha Proportional Counting

BPC - Beta Proportional Counting

LSC - Liquid Scintillation Counting 
WHC-SD-WM-ER-358 REV 0

Physical

Properties PT - Physical Testing

DM - Direct Measurement

DSC - Differential Scanning Calorimetry

TGA - Thermogravimetric Analysis

\section{A.3 Column Headings}

A.3.1 The "Analyte" column contains, in addition to the name of the analyte or physical characteristic, information about the method of measurement and, in the case of the metais, information about the method of digestion. The method of digestion is listed for the metals because, unlike the other analytes, different digestion procedures are typically used for the same metal.

Possible digestion methods are: $d$ - direct; a - acid digestion; $w$ - water leach; and $f$ potassium hydroxide fusion followed by acid digestion.

The analyte and method are presented as follows: "method.analyte", or, (in the case of a metall "method.digestion.analyte". For example, the specific concentration of ${ }^{90} \mathrm{Sr}$ was measured with a beta proportional counter and is listed "BPC. ${ }^{90} \mathrm{Sr}$ ". The specific concentration of $\mathrm{Pb}$ was determined by the inductively coupled plasma method which was preceded by acid digestion, and is listed as "ICP.a.Pb".

A.3.2 The "Laboratory Sample Identification" column lists the samples for which the analyte was measured. The "Sampling Identification Number" is different from the number assigned to the samples at the tank farm. Sampling rationale, locations, and descriptions of sampling events are contained in Section 3.0. Note that the results for $\mathrm{SO}_{4}$ and $\mathrm{PO}_{4}$ are from heated samples.

A.3.3 "Analytical Data Result" is the specific concentration of the analyte determined at different sampling points. No quality control data such as matrix spikes, serial dilutions, or duplicate analyses are listed. This information may be obtained from the Tank 241-AP-102 data package (Duchsherer, M.J., 1993). Data which was qualified as estimated (denoted by "J" or "UJ" in the data package) has been enclosed in parentheses, i.e., (395) ug/mL. Unusable data (denoted by " $R$ " in the data package) has been entered with a strikeout, i.e., $395 \mathrm{ug} / \mathrm{mL}$. Unqualified data will be entered in standard form.

A.3.4 "Standard Error" is computed for those results greater than the detection limit.

A.3.5 The "Range of Values" column lists the highest and the lowest values for a particular analyte.

A.3.6 The "Evaluated Data Result" is derived as discussed in Section 5.0.

A.3.7 The "Projected Inventory", is the product of the concentration of the analyte and the volume of the waste in the tank. $\left(4.18 \times 10^{6} \mathrm{~L}\right.$, as of Dec. 1993). 


\section{LIST OF TABLES FOR APPENDIX A}

Table A-1. Tank 241-AP-102 Analytical Data:

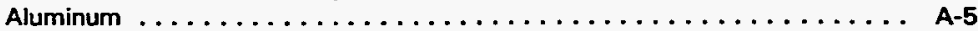

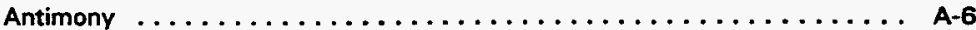

Arsenic . . . . . . . . . . . . . . . . . .

Barium . . . . . . . . .

Beryllium . . . . . . . . . . . .

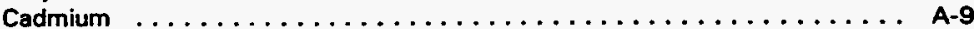

Chromium .............................. A-10

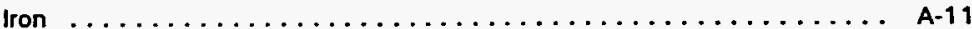

Lead ..............................A A-12

Mercury ............................ A-12

Nickel ............................... A-13

Phosphorus ............................. A-14

Potassium .......................... A-15

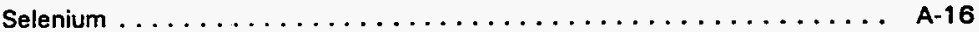

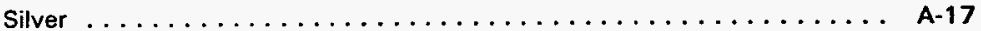

Sodium ........................... A-18

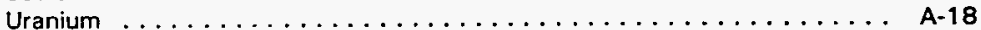

Table A-2. Tank 241-AP-102 Analytical Data:

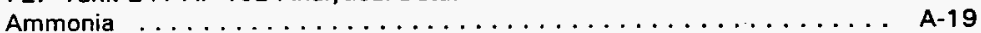

Chloride ............................. A-19

Cyanide ............................... A 20

Fluoride .............................. A-20

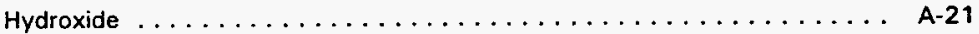

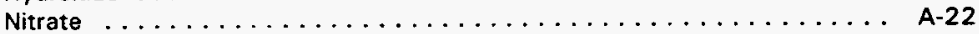

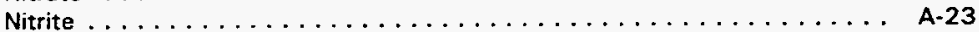

Phosphate ............................ A-24

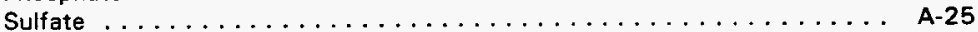

Table A-3. Tank 241-AP-102 Analytical Data:

Americium-241 ........................... A-26

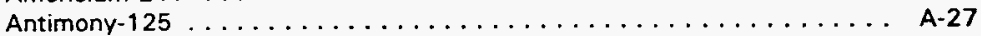

Carbon-14 ........................... A-28

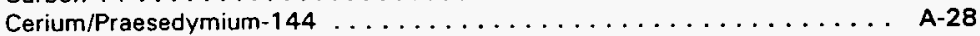

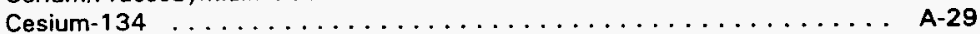

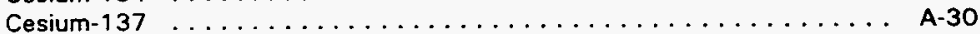

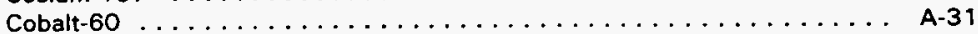

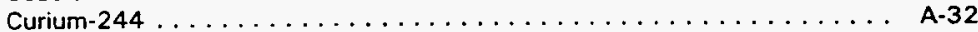

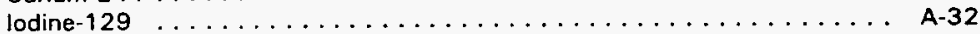

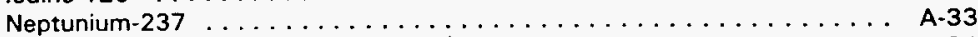

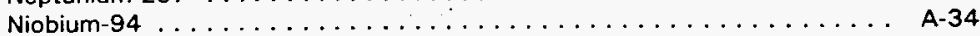

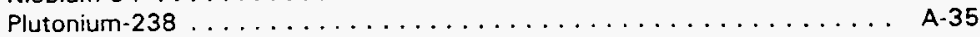

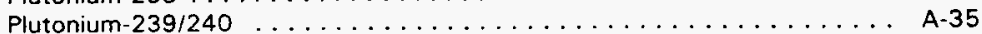

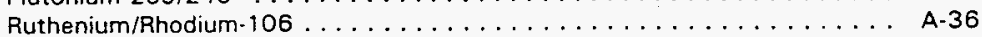

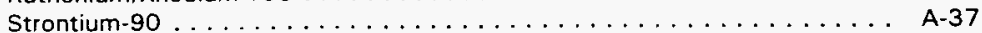

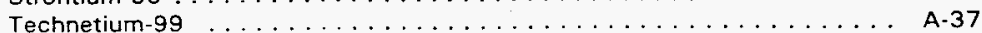

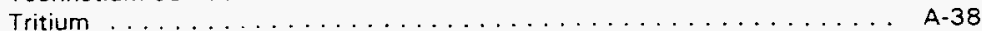

LATA-TCR-9401, Rev. 1 A-3 
Table A-4. Tank 241-AP-102 Analytical Data:

Organic Complexant Analyses $\ldots \ldots \ldots \ldots \ldots \ldots \ldots \ldots \ldots \ldots \ldots \ldots \ldots$

Table A-5. Tank 241-AP-102 Analytical Data:

Percent Water ....................... A

Specific Gravity ........................ A-40

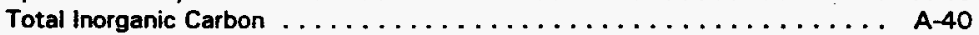

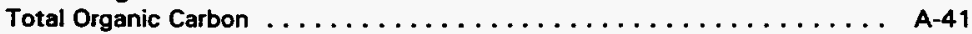

Table A-6. Tank 241-AP-102 Analytical Data:

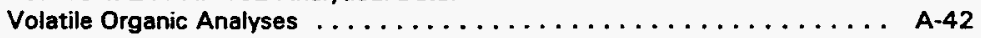

Table A-7. Tank 241-AP-102 Analytical Data:

Semivolatile Organic Analyses $\ldots \ldots \ldots \ldots \ldots \ldots \ldots \ldots \ldots \ldots$ A-43

Table A-8. Tank 241-AP-102 Analytical Data:

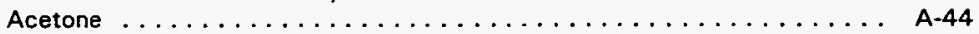

1-Butanol ...................... A-44

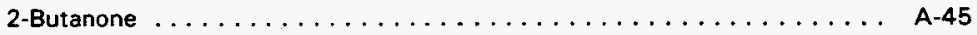

Toluene ..................... A-45

LATA-TCR-9401, Rev. $1 \quad$ A-4 


\section{WHC-SD-WM-ER-358 REV O}

Table A-1. Tank 241-AP-102 Analytical Data: Aluminum

\begin{tabular}{|c|c|c|c|c|c|c|}
\hline Andwa & 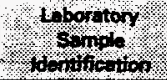 & $\begin{array}{l}\text { Andytical } \\
\text { pota } \\
\text { port }\end{array}$ & $\begin{array}{l}\text { Renos } \\
\text { Ylof }\end{array}$ & $\begin{array}{l}\text { Stateticed } \\
\text { moan }\end{array}$ & $\begin{array}{l}\text { St wdard } \\
\text { Enor } \\
\text { Whos }\end{array}$ & $\begin{array}{l}\text { Protocted } \\
\text { pritory }\end{array}$ \\
\hline Metals & & $\mu q \Omega$ & $\operatorname{sg} /$ & $\mu \boldsymbol{g} /$ & $\mu g / L$ & $\mathrm{~kg}$ \\
\hline \multirow[t]{19}{*}{ ICP.a.AI } & Sample G342 & $(1.15 E+07)$ & \multirow{19}{*}{$\begin{array}{c}1.12 E+07 \\
\text { to } \\
1.19 E+07\end{array}$} & \multirow[t]{19}{*}{$1.18 E+07$} & \multirow[t]{19}{*}{43,400} & \multirow[t]{19}{*}{48,500} \\
\hline & Semple 6449 & $(1.15 E+07)$ & & & & \\
\hline & Sample G450 & $(1.18 E+07)$ & & & & \\
\hline & Sample G348 & (1.17E+07) & & & & \\
\hline & Sample G349 & $(1.19 E+07)$ & & & & \\
\hline & Sample $\mathbf{G 3 5 2}$ & $(1.15 E+07)$ & & & & \\
\hline & Sample 6453 & $(1.17 E+07)$ & & & & \\
\hline & Sample $\mathbf{6 3 5 3}$ & $(1.13 E+07)$ & & & & \\
\hline & Sample G358 & $(1.14 E+07)$ & & & & \\
\hline & Sample G454 & $(1.17 E+07)$ & & & & \\
\hline & Sample G359 & $(1.12 E+07)$ & & & & \\
\hline & Sample G363 & $(1.14 E+07)$ & & & & \\
\hline & Sample G364 & $(1.15 E+07)$ & & & & \\
\hline & Sample G333 & $(1.14 E+07\}$ & & & & \\
\hline & Sample G459 & $(1.17 E+07)$ & & & & \\
\hline & Sample G460 & $(1.15 E+07)$ & & & & \\
\hline & Sample G338 & $(1.17 E+07)$ & & & & \\
\hline & Sample G341 & $(1.16 E+07)$ & & & & \\
\hline & Sample G443 & $(1.16 E+07)$ & & & & \\
\hline
\end{tabular}


WHC-SD-WM-ER-358 REV 0

Table A-1. Tank 241-AP-102 Analytical Data: Antimony

\begin{tabular}{|c|c|c|c|c|c|c|}
\hline Analyto & 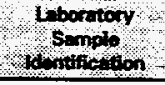 & $\begin{array}{l}\text { Andricel } \\
\text { Date } \\
\text { nomil }\end{array}$ & $\begin{array}{l}\text { Ronge } \\
\text { of } \\
\text { yous }\end{array}$ & simple Mear & 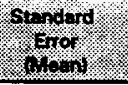 & Yopotod \\
\hline Metals & & $\boldsymbol{m} / \mathrm{L}$ & $\mu \varphi$ & $\mu g /$ & $\mu, \Omega$ & $\mathrm{kg}$ \\
\hline \multirow[t]{19}{*}{ ICP.a.Sb } & Samplo $\mathbf{6 3 4 2}$ & $(6,950)$ & \multirow{19}{*}{$\begin{array}{c}<5,250 \\
\text { to } \\
7,500\end{array}$} & \multirow[t]{19}{*}{6,610} & \multirow[t]{19}{*}{ N/A } & \multirow[t]{19}{*}{27.6} \\
\hline & Sempie G449 & $(<5,250)$ & & & & \\
\hline & Sample G450 & $<5,620$ & & & & \\
\hline & Sample G348 & $(<5,250)$ & & & & \\
\hline & Semple G349 & $(<5.250)$ & & & & \\
\hline & Sample G352 & $(<5,250)$ & & & & \\
\hline & Sample G453 & $<6,220$ & & & & \\
\hline & Sample G353 & $\{<5,250)$ & & & & \\
\hline & Sample G358 & $\{<5,250\}$ & & & & \\
\hline & Sample G454 & $(5,380)$ & & & & \\
\hline & Sample G359 & $<6,380$ & & & & \\
\hline & Sample G363 & $(7.500)$ & & & & \\
\hline & Sample G364 & $<5,250$ & & & & \\
\hline & Sample G333 & $<5,540$ & & & & \\
\hline & Sample G459 & $|<5.250|$ & & & & \\
\hline & Sample G460 & $\mid<5,250\}$ & & & & \\
\hline & Sample G338 & $<5,900$ & & & & \\
\hline & Sample G341 & $<5,620$ & & & & \\
\hline & Sample G443 & $<5,250$ & & & & \\
\hline
\end{tabular}

Table A-1. Tank 241-AP-102 Analytical Data: Arsenic

\begin{tabular}{|c|c|c|c|c|c|c|}
\hline Anatyte & $\begin{array}{l}\text { Laboratory } \\
\text { Sample } \\
\text { Jdentification }\end{array}$ & $\begin{array}{c}\text { Aralytical } \\
\text { Data } \\
\text { Resutt }\end{array}$ & $\begin{array}{c}\text { Pange } \\
\text { of } \\
V \text { ghas }\end{array}$ & Simple Mean & $\begin{array}{c}\text { Standard Erot } \\
\text { (Mean) }\end{array}$ & $\begin{array}{l}\text { Projected } \\
\text { Inventory }\end{array}$ \\
\hline Metals & & $\mu g /$ & $\mu \mathrm{g} / \mathrm{L}$ & $\mu g h$ & $\mu \mathrm{g} / \mathrm{L}$ & kg \\
\hline GHAA.a.As & Sample G443 & 88.7 & N/A & 88.7 & N/A & 0.371 \\
\hline
\end{tabular}


Table A-1. Tank 241-AP-102 Analytical Data: Barium

\begin{tabular}{|c|c|c|c|c|c|c|}
\hline Andyte & $\begin{array}{l}\text { Leboratory } \\
\text { Somple } \\
\text { dentigetion }\end{array}$ & $\begin{array}{c}\text { Apsirticel } \\
\text { pets } \\
\text { plts }\end{array}$ & 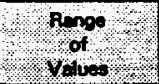 & 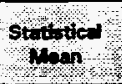 & Shandong & Projotod \\
\hline Metais & & $\mu \mathrm{g} / \mathrm{L}$ & 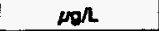 & $\boldsymbol{\mu} / \mathbf{L}$ & $\mu \mathrm{g}$ & kg \\
\hline \multirow[t]{19}{*}{ ICP.a.Ba } & Sample G342 & $(214)$ & \multirow{19}{*}{$\begin{array}{c}130 \\
\text { to } \\
392\end{array}$} & \multirow[t]{19}{*}{284} & \multirow[t]{19}{*}{18.8} & \multirow[t]{19}{*}{1.19} \\
\hline & Sample G449 & 340 & & & & \\
\hline & Sample G450 & 357 & & & & \\
\hline & Sample G348 & 264 & & & & \\
\hline & Sample G349 & 332 & & & & \\
\hline & Sample G352 & $(281)$ & & & & \\
\hline & Sample G453 & $(273)$ & & & & \\
\hline & Sample G353 & (313) & & & & \\
\hline & Sample G358 & 243 & & & & \\
\hline & Sample G454 & 333 & & & & \\
\hline & Sample G359 & 305 & & & & \\
\hline & Sample G363 & 288 & & & & \\
\hline & Sample G364 & $\{130\}$ & & & & \\
\hline & Sample G333 & (317) & & & & \\
\hline & Sample G459 & $(262)$ & & & & \\
\hline & Sample G460 & $(230)$ & & & & \\
\hline & Sample G338 & $(392)$ & & & & \\
\hline & Sample G341 & (211) & & & & \\
\hline & Sample G443 & (194) & & & & \\
\hline
\end{tabular}


Table A-1. Tank 241-AP-102 Anahytical Data: Beryllium

\begin{tabular}{|c|c|c|c|c|c|c|}
\hline Andrtse & 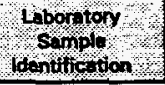 & Anatgo & 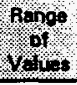 & stotistol & 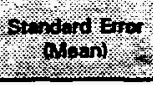 & Thointed \\
\hline Metals & & $\omega /$ & $\mu / 2$ & $\mu 0 / 2$ & $\mu \boldsymbol{\mu} /$ & 40 \\
\hline \multirow[t]{19}{*}{ ICP.a.Be } & Sample G342 & 148 & \multirow{19}{*}{$\begin{array}{c}127 \\
10 \\
160\end{array}$} & \multirow[t]{19}{*}{146} & \multirow[t]{19}{*}{2.45} & \multirow[t]{19}{*}{0.610} \\
\hline & Sample 6449 & $(127)$ & & & & \\
\hline & Sample G450 & $(128)$ & & & & \\
\hline & Sample 6348 & $\{147\}$ & & & & \\
\hline & Sample G349 & (144) & & & & \\
\hline & Sample $\mathbf{6 3 5 2}$ & 145 & & & & \\
\hline & Sample $\mathbf{6 4 5 3}$ & 155 & & & & \\
\hline & Sample G353 & 138 & & & & \\
\hline & Sample G358 & 145 & & & & \\
\hline & Sample G454 & 160 & & & & \\
\hline & Sample G359 & 135 & & & & \\
\hline & Sample G363 & 142 & & & & \\
\hline & Sample G364 & $(148)$ & & & & \\
\hline & Sample G333 & 158 & & & & \\
\hline & Sample G459 & $(152)$ & & & & \\
\hline & Sample G460 & 153 & & & & \\
\hline & Sample G338 & 158 & & & & \\
\hline & Sample G341 & 150 & & & & \\
\hline & Sample G443 & 146 & & & & \\
\hline
\end{tabular}


WHC-SD-WM-ER-358 REV O

Table A-1. Tank 24 I-AP-102 Analytical Data: Cadminm

\begin{tabular}{|c|c|c|c|c|c|c|}
\hline 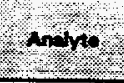 & $\begin{array}{c}\text { Leboratory } \\
\text { somplo }\end{array}$ & Aplophl & 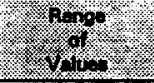 & Stotipuled & Stor or onos & Kowpotod \\
\hline Metals & & $\mu g /$ & $\mu \sigma /$ & $\mu g \Omega$ & $\mu g / L$ & kg \\
\hline \multirow[t]{19}{*}{ KCP.a.cd } & Sample G342 & 1,450 & \multirow{19}{*}{$\begin{array}{c}1,330 \\
\text { to } \\
1,650\end{array}$} & \multirow[t]{19}{*}{1,470} & \multirow[t]{19}{*}{19.7} & \multirow[t]{19}{*}{6.14} \\
\hline & Semple $\mathbf{G 4 4 9}$ & 1,390 & & & & \\
\hline & Semple G450 & $(1,430)$ & & & & \\
\hline & Semple 6348 & 1,360 & & & & \\
\hline & Semple G349 & 1,540 & & & & \\
\hline & Sample G352 & $(1,390)$ & & & & \\
\hline & Sample G453 & $(1,650)$ & & & & \\
\hline & Sample $\mathbf{6 3 5 3}$ & $(1,470)$ & & & & \\
\hline & Sample G358 & $(1,390)$ & & & & \\
\hline & Sample G454 & $\{1,590\}$ & & & & \\
\hline & Sample G359 & $(1,330)$ & & & & \\
\hline & Sample G363 & $(1,490)$ & & & & \\
\hline & Sample G364 & $(1,560)$ & & & & \\
\hline & Sample G333 & 1,470 & & & & \\
\hline & Sample G459 & 1,470 & & & & \\
\hline & Sample G460 & $(1,470)$ & & & & \\
\hline & Sample G338 & 1,500 & & & & \\
\hline & Sample G341 & 1.470 & & & & \\
\hline & Sample G443 & {$[1,500)$} & & & & \\
\hline
\end{tabular}


Table A-1. Tank 241-AP-102 Analytical Data: Chromium

\begin{tabular}{|c|c|c|c|c|c|c|}
\hline 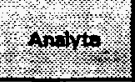 & Wobratoy & Anpopos & 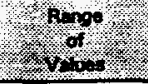 & $\begin{array}{l}\text { Statistical } \\
\text { Merh }\end{array}$ & Strindard bjor & 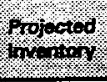 \\
\hline Metals & & $\mu g \Omega$ & LN/ & $\mu g /$ & $\mu g / L$ & $\mathbf{k g}$ \\
\hline \multirow[t]{19}{*}{ ICP.e.Cr } & Sample G342 & $6.13 E+05$ & \multirow{19}{*}{$\begin{array}{c}5.99 E+05 \\
t 0 \\
8.50 E+05\end{array}$} & \multirow[t]{19}{*}{$6.18 E+05$} & \multirow[t]{19}{*}{2,850} & \multirow[t]{19}{*}{2,580} \\
\hline & Semple G449 & $6.06 \mathrm{E}+05$ & & & & \\
\hline & Sample 6450 & $6.06 E+05$ & & & & \\
\hline & Sample G348 & $6.36 \mathrm{E}+05$ & & & & \\
\hline & Sample G349 & $6.50 E+05$ & & & & \\
\hline & Sample G352 & $6.16 E+05$ & & & & \\
\hline & Sample G453 & $(6.30 E+05)$ & & & & \\
\hline & Sample G353 & $6.19 E+05$ & & & & \\
\hline & Sample G358 & $(6.10 E+05)$ & & & & \\
\hline & Sample G454 & $(6.15 E+05)$ & & & & \\
\hline & Sample 6359 & $(5.99 E+05)$ & & & & \\
\hline & Sample $\mathbf{6 3 6 3}$ & $6.10 E+05$ & & & & \\
\hline & Sample G364 & $6.16 E+05$ & & & & \\
\hline & Sample G333 & $6.25 E+05$ & & & & \\
\hline & Sample G459 & $(6.19 E+05)$ & & & & \\
\hline & Sample G460 & $(6.23 E+05\}$ & & & & \\
\hline & Sample 6338 & $6.24 E+05$ & & & & \\
\hline & Sample G341 & $6.23 E+05$ & & & & \\
\hline & Sample G443 & $6.23 E+05$ & & & & \\
\hline
\end{tabular}


Table A-1. Tank 241-AP-102 Analytical Data: Iron

\begin{tabular}{|c|c|c|c|c|c|c|}
\hline An $h t=$ & Lbortort & $\begin{array}{l}\text { Anphricel } \\
\text { popta } \\
\text { frest }\end{array}$ & 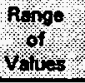 & Stutistical & $\begin{array}{l}\text { Stondard Enor } \\
\text { (n) }\end{array}$ & $\begin{array}{l}\text { propeted } \\
\text { Whitoh }\end{array}$ \\
\hline Metals & & 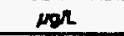 & $\mu g /$ & $\operatorname{mg} h$ & $\operatorname{\mu g} \Omega$ & kg \\
\hline \multirow[t]{19}{*}{ ICP.a.Fe } & Semple $\mathbf{6 3 4 2}$ & $(3,780)$ & \multirow{19}{*}{$\begin{array}{c}2,910 \\
\text { to } \\
6,500\end{array}$} & \multirow[t]{19}{*}{3,810} & \multirow[t]{19}{*}{295} & \multirow[t]{19}{*}{15.9} \\
\hline & Semple G449 & $(3,130)$ & & & & \\
\hline & Sample G450 & $(3,100)$ & & & & \\
\hline & Semple G348 & $(6.080)$ & & & & \\
\hline & Semple G349 & $(2,970)$ & & & & \\
\hline & Sample $\mathbf{G 3 5 2}$ & $(2,950)$ & & & & \\
\hline & Sample G453 & $(5,910)$ & & & & \\
\hline & Sample G353 & $(4,180)$ & & & & \\
\hline & Sample G358 & $(6,500)$ & & & & \\
\hline & Sample G454 & $(3,470)$ & & & & \\
\hline & Sample 6359 & $(3,140)$ & & & & \\
\hline & Sample G363 & $(3,130)$ & & & & \\
\hline & Sample G364 & $(3,620)$ & & & & \\
\hline & Sample $\mathrm{G333}$ & $(2,910)$ & & & & \\
\hline & Sample 6459 & $(3,1 ; 0)$ & & & & \\
\hline & Sample G460 & $(3,970)$ & & & & \\
\hline & Sample G338 & $(3,490)$ & & & & \\
\hline & Sample G341 & $(3,480)$ & & & & \\
\hline & Sample G443 & $(5,610)$ & & & & \\
\hline
\end{tabular}


Table A-1. Tank 241-AP-102 Analytical Data: Lead

\begin{tabular}{|c|c|c|c|c|c|c|}
\hline Anolyte & Loborrion & $\begin{array}{c}\text { Anphicel } \\
\text { pats } \\
\text { powh }\end{array}$ & $\begin{array}{l}\text { nange } \\
\text { of } \\
\text { Values }\end{array}$ & Simple Noen & Stymond Error & $\begin{array}{l}\text { Projectod } \\
\text { Inventory }\end{array}$ \\
\hline Motals & & $\operatorname{mor}$ & $\mu g /$ & $\mu /$ & $\mu g /$ & $\mathrm{kg}$ \\
\hline \multirow[t]{19}{*}{ ICP.a.Pb } & Semple G342 & $<1,550$ & \multirow{19}{*}{$\begin{array}{c}<1,550 \\
\text { to } \\
5,330\end{array}$} & \multirow[t]{19}{*}{3,290} & \multirow[t]{19}{*}{$N / A$} & \multirow[t]{19}{*}{13.8} \\
\hline & Sample 6449 & $<1.550$ & & & & \\
\hline & Sample G450 & $<1,550$ & & & & \\
\hline & Sample $\mathbf{G 3 4 8}$ & $(<1,550)$ & & & & \\
\hline & Sample G349 & $(2,640)$ & & & & \\
\hline & Sample G352 & $<1,550$ & & & & \\
\hline & Sample G453 & $(<1,550)$ & & & & \\
\hline & Sample G353 & $<1,550$ & & & & \\
\hline & Sample G358 & $(<1,550)$ & & & & \\
\hline & Sample G454 & $(1,950)$ & & & & \\
\hline & Sample G359 & $\{3,220\}$ & & & & \\
\hline & Sample 6363 & $(<1,550)$ & & & & \\
\hline & Sample G364 & $(5,330)$ & & & & \\
\hline & Sample G333 & $(<1,550)$ & & & & \\
\hline & Sample G459 & $<1.550$ & & & & \\
\hline & Sample G460 & $<1,550$ & & & & \\
\hline & Sample G338 & $(<1,550)$ & & & & \\
\hline & Sample G341 & $<1,550$ & & & & \\
\hline & Sample G443 & $<1.550$ & & & & \\
\hline
\end{tabular}

Table A-1. Tank 241-AP-102 Analytical Data: Mercury

\begin{tabular}{|c|c|c|c|c|c|c|}
\hline Analyte & $\begin{array}{l}\text { Laboratory } \\
\text { Sample } \\
\text { Identification }\end{array}$ & $\begin{array}{c}\text { Analytical } \\
\text { Data } \\
\text { Result }\end{array}$ & $\begin{array}{c}\text { Range } \\
\text { of } \\
\text { Values }\end{array}$ & $\begin{array}{l}\text { Lergest } \\
\text { Detection } \\
\text { Limit }\end{array}$ & $\begin{array}{c}\text { Standard Error } \\
\text { (Mean) }\end{array}$ & $\begin{array}{l}\text { Projected } \\
\text { Inventory }\end{array}$ \\
\hline Metals & & $\mu \mathrm{g} /$ & $\mu g / 2$ & $\mu g / L$ & $\mu g / h$ & $\mathrm{~kg}$ \\
\hline CVAA.a.Hg & Sample G443 & $<5.00$ & N/A & $<5.00$ & $N / A$ & $<0.0209$ \\
\hline
\end{tabular}


WHC-SD-WM-ER-358 REV 0

Table A-1. Tank 241-AP-102 Analytical Data: Nickel

\begin{tabular}{|c|c|c|c|c|c|c|}
\hline Anabre, & $\begin{array}{l}\text { Leboretory } \\
\text { spmpte } \\
\text { ldof pication }\end{array}$ & $\begin{array}{l}\text { Andytical } \\
\text { Data }\end{array}$ & $\begin{array}{l}\text { Range } \\
\text { of } \\
\text { Vohues }\end{array}$ & Strtivtot & $\mathrm{sc} / \mathrm{dr} \mathrm{stor}$ & $\begin{array}{l}\text { Propeted } \\
\text { Wentory }\end{array}$ \\
\hline Metals & & $\log \Omega$ & $\mu O / L$ & $\mu 0 \Omega$ & $\mu a /$ & kg \\
\hline \multirow[t]{19}{*}{ ICP.a.Ni } & Sample G342 & 26,300 & \multirow{19}{*}{$\begin{array}{c}25,900 \\
\text { to } \\
28,000\end{array}$} & \multirow[t]{19}{*}{26,600} & \multirow[t]{19}{*}{124} & \multirow[t]{19}{*}{111} \\
\hline & Semple G449 & $(26,000)$ & & & & \\
\hline & Sample G450 & $(26.200)$ & & & & \\
\hline & Sample 6348 & 27,500 & & & & \\
\hline & Sample G349 & 28,000 & & & & \\
\hline & Sample G352 & 26,300 & & & & \\
\hline & Sample G453 & $(27,100)$ & & & & \\
\hline & Sample G353 & 26,400 & & & & \\
\hline & Sample G358 & $(26,300)$ & & & & \\
\hline & Sample G454 & $(26,600)$ & & & & \\
\hline & Sample G359 & $(25,900)$ & & & & \\
\hline & Sample $\mathbf{6 3 6 3}$ & 26.400 & & & & \\
\hline & Sample G364 & 26,500 & & & & \\
\hline & Sample G333 & $(26,900)$ & & & & \\
\hline & Sample G459 & $(26,700)$ & & & & \\
\hline & Sample G460 & $(26,600)$ & & & & \\
\hline & Sample G338 & $(26.800)$ & & & & \\
\hline & Sample G341 & 26,900 & & & & \\
\hline & Sample G443 & $(27,000)$ & & & & \\
\hline
\end{tabular}


Table A-1. Tank 241-AP-102 Analytical Data: Phosphorus

\begin{tabular}{|c|c|c|c|c|c|c|}
\hline Andyte & $\begin{array}{l}\text { Laboratory } \\
\text { Sarnple } \\
\text { odentification }\end{array}$ & $\begin{array}{c}\text { Anohrtical } \\
\text { Data } \\
\text { Pesult }\end{array}$ & $\begin{array}{l}\text { Range } \\
\text { of } \\
\text { Values }\end{array}$ & $\begin{array}{l}\text { Statistical } \\
\text { Moth }\end{array}$ & Standard Erro & $\begin{array}{l}\text { Projected } \\
\text { inventory }\end{array}$ \\
\hline Metais & & $\mu / L$ & $\mu g / L$ & $\mu \sigma / L$ & $\mu \mathrm{g} /$ & $\mathbf{k g}$ \\
\hline \multirow[t]{19}{*}{ ICP.A.P } & Sample G342 & $(3.03 E+06)$ & \multirow{19}{*}{$\begin{array}{c}2.60 E+06 \\
\text { to } \\
3.44 E+06\end{array}$} & \multirow[t]{19}{*}{$3.06 E+06$} & \multirow[t]{19}{*}{62,700} & \multirow[t]{19}{*}{12,800} \\
\hline & Sample G449 & $(2.93 E+06)$ & & & & \\
\hline & Sample G450 & (3.03E + 06) & & & & \\
\hline & Sample G348 & $(2.99 E+06)$ & & & & \\
\hline & Sample G349 & $(3.19 E+06)$ & & & & \\
\hline & Sample G352 & $(2.88 E+06)$ & & & & \\
\hline & Sample G453 & $(3.42 \mathrm{E}+06)$ & & & & \\
\hline & Sample G353 & $(2.84 E+06)$ & & & & \\
\hline & Sample $\mathbf{6 3 5 8}$ & $(2.92 E+06)$ & & & & \\
\hline & Sample G454 & $(3.40 E+05)$ & & & & \\
\hline & Sample G359 & $(3.04 E+06)$ & & & & \\
\hline & Sample G363 & $(2.63 E+06)$ & & & & \\
\hline & Sample G364 & $(2.60 E+06)$ & & & & \\
\hline & Sample G333 & $(3.27 E+06)$ & & & & \\
\hline & Sample G459 & $(3.22 E+06)$ & & & & \\
\hline & Sample G460 & $(3.13 E+06)$ & & & & \\
\hline & Sample G338 & $(3.44 E+06)$ & & & & \\
\hline & Sample G341 & $(3.06 E+06)$ & & & & \\
\hline & Sample G443 & $2.86 E+06$ & & & & \\
\hline
\end{tabular}


Table A-1. Tonk 241-AP-102 Analytical Data: Potassium

\begin{tabular}{|c|c|c|c|c|c|c|}
\hline $\mathrm{x}^{\mathrm{x}}$ & 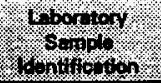 & Aroutcol & 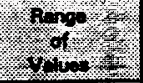 & 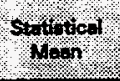 & 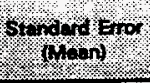 & Woropod \\
\hline Motals & & $\cos$ & $\mathrm{mor}$ & $\mu \sigma / L$ & $\boldsymbol{\omega} \boldsymbol{\omega}$ & $\mathbf{k g}$ \\
\hline \multirow[t]{19}{*}{ ICP.e.K } & Sample G342 & $(1.30 E+08)$ & \multirow{19}{*}{$\begin{array}{c}1.20 E+08 \\
\text { to } \\
1.33 E+06\end{array}$} & \multirow[t]{19}{*}{$1.29 E+06$} & \multirow{19}{*}{9,840} & \multirow[t]{19}{*}{5,390} \\
\hline & Sample G449 & $(1.29 E+06)$ & & & & \\
\hline & Sample G450 & $(1.30 E+06)$ & & & & \\
\hline & Sample G348 & $(1.26 E+06)$ & & & & \\
\hline & Sample G349 & $(1.28 E+06)$ & & & & \\
\hline & Sample G352 & $(1.25 E+06)$ & & & & \\
\hline & Sample G453 & $(1.33 E+06)$ & & & & \\
\hline & Sample G353 & $(1.26 E+06)$ & & & & \\
\hline & Sample G358 & $(1.21 E+06)$ & & & & \\
\hline & Sample G454 & $(1.31 E+06)$ & & & & \\
\hline & Sample G359 & $\{1.20 E+06\}$ & & & & \\
\hline & Sample G363 & $\{1.29 E+06\}$ & & & & \\
\hline & Sample G364 & $(1.32 E+06)$ & & & & \\
\hline & Sample G333 & $(1.31 E+06)$ & & & & \\
\hline & Sample G459 & $(1.30 E+06)$ & & & & \\
\hline & Sample G460 & $(1.32 \varepsilon+06)$ & & & & \\
\hline & Sample G338 & $(1.33 E+06)$ & & & & \\
\hline & Sample G341 & $(1.32 E+06)$ & & & & \\
\hline & Sample G443 & $(1.32 E+06)$ & & & & \\
\hline
\end{tabular}


Table A-1. Tank 241-AP-102 Anahytical Data: Selenium

\begin{tabular}{|c|c|c|c|c|c|c|}
\hline $\mathrm{Aln}^{1 / 2}$ & 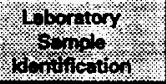 & 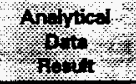 & 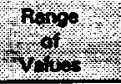 & Statipteal & 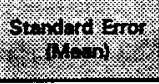 & Projagtod \\
\hline Metal & & $\mu g / m L$ & $\mu \mathrm{g} / \mathrm{mL}$ & $\mu g / m L$ & $\mu g / m L$ & $\mathrm{~kg}$ \\
\hline \multirow[t]{13}{*}{ GHAA.Se } & Sample G342 & 0.364 & \multirow{13}{*}{$\begin{array}{c}0.260 \text { to } \\
0.463\end{array}$} & \multirow[t]{13}{*}{0.367} & \multirow[t]{13}{*}{0.0184} & \multirow[t]{13}{*}{1.53} \\
\hline & Sample G348 & 0.329 & & & & \\
\hline & Sample 6349 & 0.302 & & & & \\
\hline & Sample G352 & 0.463 & & & & \\
\hline & Sample G353 & 0.460 & & & & \\
\hline & Semple G358 & 0.397 & & & & \\
\hline & Sample G359 & 0.372 & & & & \\
\hline & Semple G363 & 0.445 & & & & \\
\hline & Sample G364 & 0.260 & & & & \\
\hline & Sample 6459 & 0.370 & & & & \\
\hline & Sample G460 & 0.378 & & & & \\
\hline & Sample G341 & 0.346 & & & & \\
\hline & Sample G443 & 0.412 & & & & \\
\hline
\end{tabular}


Table A-1. Tank 241-AP-102 Analytical Data: Silver

\begin{tabular}{|c|c|c|c|c|c|c|}
\hline $\mathrm{Anth}_{\mathrm{N}}$ & 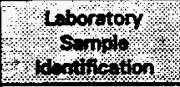 & 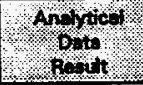 & 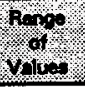 & 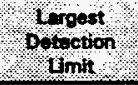 & Shonderd Eno & 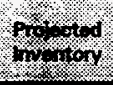 \\
\hline Mot'ls & & $\mu g / L$ & $\operatorname{mg} h$ & $\mu g / L$ & $\mu / L$ & $\mathbf{k g}$ \\
\hline \multirow[t]{19}{*}{ ICP.a.AB } & Sample 6342 & $(<125)$ & \multirow[t]{19}{*}{ N/A } & \multirow[t]{19}{*}{$<125$} & \multirow[t]{19}{*}{$\mathbf{N} / \mathbf{A}$} & \multirow[t]{19}{*}{$<0.523$} \\
\hline & Semple G449 & $(<125)$ & & & & \\
\hline & Sanple G450 & $\{<125\}$ & & & & \\
\hline & Sample G348 & $(<125)$ & & & & \\
\hline & Sample $\mathbf{6 3 4 9}$ & $(<125)$ & & & & \\
\hline & Semple G352 & $(<125)$ & & & & \\
\hline & Semple G453 & $1<125)$ & & & & \\
\hline & Semple G353 & $1<125)$ & & & & \\
\hline & Sample G358 & $(<125)$ & & & & \\
\hline & Sample G454 & $(<125)$ & & & & \\
\hline & Sample G359 & $(<125)$ & & & & \\
\hline & Sample G363 & $(<125)$ & & & & \\
\hline & Sample G364 & $1<125)$ & & & & \\
\hline & Sample G333 & $1<125\}$ & & & & \\
\hline & Sample G459 & $(<125)$ & & & & \\
\hline & Sample G460 & $(<125)$ & & & & \\
\hline & Semple 6338 & $(<125)$ & & & & \\
\hline & Sample G341 & $(<125)$ & & & & \\
\hline & Sample G443 & $1<125)$ & & & & \\
\hline
\end{tabular}


Table A-1. Tank 241-AP-102 Analytical Data: Sodium

\begin{tabular}{|c|c|c|c|c|c|c|}
\hline Anlyte & 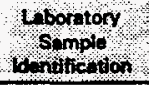 & $\begin{array}{l}\text { Anahyical } \\
\text { Dota } \\
\text { Bonts }\end{array}$ & $\begin{array}{l}\text { parop } \\
\text { of }\end{array}$ & $\begin{array}{l}\text { Statistied } \\
\text { Meen }\end{array}$ & $\begin{array}{l}\text { Stonderd } \\
\text { Enol } \\
\text { Whol }\end{array}$ & Poporom \\
\hline Metals & & $\mu \rho /$ & $\mu g /$ & $\mu g \Omega$ & $\mu /$ & kg \\
\hline \multirow[t]{19}{*}{ - ICP.a.Na } & Somple G342 & $(1.00 E+08)$ & \multirow{19}{*}{$\begin{array}{c}9.85 E+07 \\
\text { to } \\
1.04 E+08\end{array}$} & \multirow[t]{19}{*}{$1.02 E+08$} & \multirow[t]{19}{*}{406,000} & \multirow[t]{19}{*}{426,000} \\
\hline & Sample G449 & $(1.01 E+08)$ & & & & \\
\hline & Sample G450 & $(1.04 E+08)$ & & & & \\
\hline & Sampla G348 & $(1.03 E+08)$ & & & & \\
\hline & Sample G349 & $(1.04 E+08)$ & & & & \\
\hline & Sample G352 & $(1.01 E+08)$ & & & & \\
\hline & Sample G453 & $(1.04 E+08)$ & & & & \\
\hline & Sample G353 & $(1.00 E+08)$ & & & & \\
\hline & Sample G358 & $(1.01 E+08)$ & & & & \\
\hline & Sample G454 & $(1.03 E+08)$ & & & & \\
\hline & Sample G359 & $(9.85 E+07)$ & & & & \\
\hline & Sample G363 & $(1.00 E+08)$ & & & & \\
\hline & Sample G364 & $(1.02 E+08)$ & & & & \\
\hline & Sample G333 & $(1.00 E+08)$ & & & & \\
\hline & Sample G459 & $(1.02 E+08)$ & & & & \\
\hline & Sample G460 & $(1.01 E+08)$ & & & & \\
\hline & Sample G338 & $\{1.03 E+08\}$ & & & & \\
\hline & Sample G341 & $(1.01 E+08)$ & & & & \\
\hline & Sample G443 & (1).02E + OB) & & & & \\
\hline
\end{tabular}

Table A-1. Tank 241-AP-102 Analytical Data: Uranium

\begin{tabular}{|c|c|c|c|c|c|c|}
\hline Anahrte & $\begin{array}{l}\text { Laboratory } \\
\text { Sample } \\
\text { Identification }\end{array}$ & $\begin{array}{c}\text { Analytical } \\
\text { Data } \\
\text { Result }\end{array}$ & $\begin{array}{c}\text { Range } \\
\text { of } \\
\text { Values }\end{array}$ & $\begin{array}{l}\text { Simple } \\
\text { Mean }\end{array}$ & $\begin{array}{l}\text { Standard Error } \\
\text { (Mean) }\end{array}$ & $\begin{array}{l}\text { Projected } \\
\text { Inventory }\end{array}$ \\
\hline Metals & & $\mu \mathrm{g} / \mathrm{L}$ & $\operatorname{lgg} \Omega$ & $\lg h$ & $\mu g / L$ & $\mathbf{k g}$ \\
\hline \multirow[t]{6}{*}{ LF.U } & Sample $\mathrm{G443}$ & 6,700 & \multirow{6}{*}{$\begin{array}{c}2,370 \\
\text { to } \\
6,700\end{array}$} & \multirow[t]{6}{*}{4,620} & \multirow[t]{6}{*}{ N/A } & \multirow[t]{6}{*}{19.3} \\
\hline & Sample G443 & 2,370 & & & & \\
\hline & Sample 6470 & 4,530 & & & & \\
\hline & Sample G471 & 4.770 & & & & \\
\hline & Sample G476 & 5.270 & & & & \\
\hline & Sample G477 & 4,050 & & & & \\
\hline
\end{tabular}


Table A-2. Tank 241-AP-102 Analytical Data: Ammonia

\begin{tabular}{|c|c|c|c|c|c|c|}
\hline Analyte & $\begin{array}{l}\text { Lboratory } \\
\text { semplifiction }\end{array}$ & $\begin{array}{l}\text { Analyticel } \\
\text { Date } \\
\text { Resutt }\end{array}$ & $\begin{array}{l}\text { Ranpe } \\
\text { of } \\
\text { velose }\end{array}$ & Stapl $M+1$ & Stardor Eror & mopoptor \\
\hline Cation & & $\mu g / m L$ & $\mu g / m L$ & $\mu 0 / \mathrm{mL}$ & $\mu 0 / m L$ & kg \\
\hline \multirow[t]{4}{*}{ KTN.NHH } & Sample G470 & $(262)$ & \multirow{4}{*}{$\begin{array}{l}198 \\
\text { to } \\
395\end{array}$} & \multirow[t]{4}{*}{273} & \multirow[t]{4}{*}{$\mathbf{N} / \mathbf{A}$} & \multirow[t]{4}{*}{1,140} \\
\hline & Sample G471 & (359) & & & & \\
\hline & Sample G476 & (198) & & & & \\
\hline & Sample G477 & $(272)$ & & & & \\
\hline
\end{tabular}

Table A-2. Tank 241-AP-102 Analytical Data: Chloride

\begin{tabular}{|c|c|c|c|c|c|c|}
\hline Analyte & $\begin{array}{l}\text { Leboratory } \\
\text { Sample } \\
\text { Identification }\end{array}$ & $\begin{array}{l}\text { Analytical } \\
\text { Data } \\
\text { Result }\end{array}$ & $\begin{array}{c}\text { Range } \\
\text { of } \\
\text { Values }\end{array}$ & Simple Mean & $\begin{array}{c}\text { Standard Error } \\
\text { (Mean) }\end{array}$ & $\begin{array}{l}\text { Projucted } \\
\text { Inventory }\end{array}$ \\
\hline Anion & & $\mu g / \mathrm{mL}$ & $\mu g / m L$ & $\mu g / m L$ & $\mu \mathrm{g} / \mathrm{mL}$ & $\mathbf{k g}$ \\
\hline \multirow[t]{19}{*}{ IC. $\mathrm{Cl}^{-}$} & Sample G342 & 2,790 & \multirow{19}{*}{$\begin{array}{l}2,710 \\
\text { to } \\
4,460\end{array}$} & \multirow[t]{19}{*}{2.900} & \multirow[t]{19}{*}{ N/A } & \multirow[t]{19}{*}{12,100} \\
\hline & Sample G449 & 2,980 & & & & \\
\hline & Sample G450 & 3,010 & & & & \\
\hline & Sample G348 & 2.710 & & & & \\
\hline & Sample G349 & 2,790 & & & & \\
\hline & Sample G352 & 2,840 & & & & \\
\hline & Sample $\mathrm{G} 453$ & 2,980 & & & & \\
\hline & Sample G353 & 2,820 & & & & \\
\hline & Sample G358 & 2,800 & & & & \\
\hline & Sample G454 & 2,910 & & & & \\
\hline & Sample G359 & 2,820 & & & & \\
\hline & Sample G363 & 2,880 & & & & \\
\hline & Sample G364 & 2,940 & & & & \\
\hline & Sample G333 & 2.920 & & & & \\
\hline & Sample G459 & 2,850 & & & & \\
\hline & Sample G460 & 3,600 & & & & \\
\hline & Sample G338 & 3,010 & & & & \\
\hline & Sample G341 & 2,800 & & & & \\
\hline & Sample G443 & 4,460 & & & & \\
\hline
\end{tabular}


Table A-2. Tank 241-AP-102 Analytical Data: Cyanida

\begin{tabular}{|c|c|c|c|c|c|c|}
\hline Anhro & Heralor & 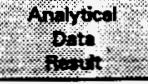 & 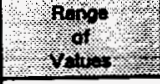 & sono & So & propord \\
\hline Anion & & $\mu / m L$ & $\mu g / m L$. & $\mu \mathrm{g} / \mathrm{mL}$ & $\mu g h L$ & $\mathbf{k g}$ \\
\hline $\begin{array}{r}\text { Dist/Spec. } \\
\text { CN }\end{array}$ & Semple G443 & 24.6 & N/A & 24.6 & $\mathbf{N} / \mathbf{A}$ & 103 \\
\hline
\end{tabular}

Table A-2. Tank 241-AP-102 Anahrical Data: Fluoride

\begin{tabular}{|c|c|c|c|c|c|c|}
\hline Analyte & $\begin{array}{l}\text { Laboratory } \\
\text { Sanpla } \\
\text { Identifiotion }\end{array}$ & $\begin{array}{l}\text { Anahytical } \\
\text { pota } \\
\text { Alosult }\end{array}$ & $\begin{array}{l}\text { Ponge } \\
\text { of } \\
\text { Yelues }\end{array}$ & Detection Limi & $\begin{array}{l}\text { St ward Error } \\
\text { AMest }\end{array}$ & $\begin{array}{l}\text { Projected } \\
\text { Imentory }\end{array}$ \\
\hline Anion & & $\mu g / m L$ & $\mu \mathrm{g} / \mathrm{mL}$ & $\mu g / m L$ & $\mu g / m L$ & kg \\
\hline \multirow[t]{19}{*}{ IC.F' } & Sample G342 & $<168$ & \multirow[t]{19}{*}{ N/A } & \multirow[t]{19}{*}{$<168$} & \multirow[t]{19}{*}{ N/A } & \multirow[t]{19}{*}{$<702$} \\
\hline & Sample G449 & $<168$ & & & & \\
\hline & Sample 6450 & $<168$ & & & & \\
\hline & Sample G348 & $<168$ & & & & \\
\hline & Sample G349 & $<168$ & & & & \\
\hline & Sample 6352 & $<168$ & & & & \\
\hline & Sampie G453 & $<168$ & & & & \\
\hline & Sample G353 & $<168$ & & & & \\
\hline & Sample 6358 & $<168$ & & & & \\
\hline & Sample G454 & $<168$ & & & & \\
\hline & Sample G359 & $<168$ & & & & \\
\hline & Sampie G363 & $<168$ & & & & \\
\hline & Sample G364 & $<168$ & & & & \\
\hline & Sample G333 & $<168$ & & & & \\
\hline & Sample G459 & $<168$ & & & & \\
\hline & Sample G460 & $<168$ & & & & \\
\hline & Sample G338 & $<168$ & & & & \\
\hline & Sample G341 & $<168$ & & & & \\
\hline & Sample G443 & $<168$ & & & & \\
\hline
\end{tabular}




\section{WHC-SD-WM-ER-358 REV O}

Table A-2. Tank 241-AP-102 Analytical Data: Hydroxide

\begin{tabular}{|c|c|c|c|c|c|c|}
\hline Ansyso & Wobororory & 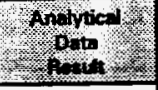 & $\mathrm{p}^{-1}+{ }^{4}$ & Stougd & xplos & molootod \\
\hline Anion & & $\mu 0 / m L$ & $\mu / m L$ & $\mu g / m L$ & $\mu \mathrm{mL}$ & $\mathrm{kg}$ \\
\hline \multirow{13}{*}{$\begin{array}{l}\text { POT Autotit. } \\
\text { OH }\end{array}$} & Sample $\mathbf{6 3 4 2}$ & 9,010 & \multirow{13}{*}{$\begin{array}{l}9,010 \text { to } \\
9,340\end{array}$} & \multirow[t]{13}{*}{9,150} & \multirow[t]{13}{*}{37.5} & \multirow[t]{13}{*}{38,200} \\
\hline & Sample $\mathbf{G 3 4 8}$ & 9,040 & & & & \\
\hline & Sample $\mathbf{6 3 4 9}$ & 9,270 & & & & \\
\hline & Sample $\mathbf{6 3 5 2}$ & 9,340 & & & & \\
\hline & Sample G353 & 9,140 & & & & \\
\hline & Sample G358 & 9,240 & & & & \\
\hline & Sample G359 & 9,080 & & & & \\
\hline & Sample G363 & 9,200 & & & & \\
\hline & Sample G364 & 9,240 & & & & \\
\hline & Sample G459 & 9,180 & & & & \\
\hline & Sample G460 & 9,080 & & & & \\
\hline & Sample G341 & 9,170 & & & & \\
\hline & Sample $\mathbf{6 4 4 3}$ & 9,110 & & & & \\
\hline
\end{tabular}


Table A-2. Tank 241-AP-102 Analytical Data: Nitrate

\begin{tabular}{|c|c|c|c|c|c|c|}
\hline 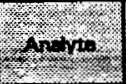 & 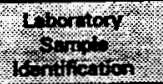 & 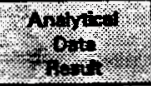 & ofot & 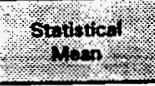 & 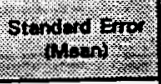 & $310,10 \mathrm{~m}$ \\
\hline Arion & & $\mu \mathrm{g} / \mathrm{mL}$ & $\mu / \mathrm{mL}$ & $\mu g / m L$ & $\mu \mathrm{g} / \mathrm{mL}$ & $\mathbf{k g}$ \\
\hline \multirow[t]{19}{*}{$\mathrm{KC.NO}{ }_{3}^{-}$} & Semple $\mathbf{6 3 4 2}$ & 75,900 & \multirow{19}{*}{$\begin{array}{c}54,800 \\
\text { to } \\
97,100\end{array}$} & \multirow[t]{19}{*}{78,200} & \multirow[t]{19}{*}{1,760} & \multirow[t]{19}{*}{ 3.27E + O5 } \\
\hline & Semple 6449 & 78,000 & & & & \\
\hline & Semple G450 & 79,200 & & & & \\
\hline & Semple G348 & 75,900 & & & & \\
\hline & Sample G349 & 76,200 & & & & \\
\hline & Sample G352 & 75,900 & & & & \\
\hline & Semple 6453 & 79,400 & & & & \\
\hline & Sample G353 & 76,100 & & & & \\
\hline & Sample G358 & 75,900 & & & & \\
\hline & Sample 6454 & 78,600 & & & & \\
\hline & Sample G359 & 77,200 & & & & \\
\hline & Sample G363 & 77.600 & & & & \\
\hline & Sample 6364 & 78,500 & & & & \\
\hline & Sample G333 & 79,400 & & & & \\
\hline & Semple G459 & 76,500 & & & & \\
\hline & Sample $\mathbf{6 4 6 0}$ & 97,100 & & & & \\
\hline & Sample G338 & 78,700 & & & & \\
\hline & Sample G341 & 76,500 & & & & \\
\hline & Sample G443 & 54,800 & & & & \\
\hline
\end{tabular}


Table A-2. Tank 241-AP-102 Analytical Data: Nitrite

\begin{tabular}{|c|c|c|c|c|c|c|}
\hline 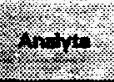 & Lerotory & 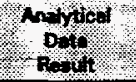 & Baph & sropods & 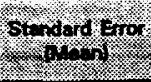 & Propos \\
\hline Anion & & $\mu \mathrm{g} / \mathrm{mL}$ & $\mu \mathrm{g} / \mathrm{mL}$ & $\mu g / m L$ & $\mu g / m L$ & ko \\
\hline \multirow[t]{19}{*}{ IC. $\mathrm{NO}_{2}^{-}$} & Semple G342 & 36,500 & \multirow{19}{*}{$\begin{array}{c}36,500 \\
\text { to } \\
54,800\end{array}$} & \multirow[t]{19}{*}{38,000} & \multirow[t]{19}{*}{1,100} & \multirow[t]{19}{*}{$1.59 E+05$} \\
\hline & Semple G449 & 38.600 & & & & \\
\hline & Semple G450 & 38,200 & & & & \\
\hline & Sample 6348 & 38,800 & & & & \\
\hline & Semple 6349 & 37.300 & & & & \\
\hline & Sample $\mathbf{6 3 5 2}$ & 36,700 & & & & \\
\hline & Simple 6453 & 38,700 & & & & \\
\hline & Semple 6353 & 36,500 & & & & \\
\hline & Sample G358 & 36,500 & & & & \\
\hline & Sample G454 & 38,500 & & & & \\
\hline & Sample 6359 & 37,200 & & & & \\
\hline & Sample G363 & 37,800 & & & & \\
\hline & Sample G364 & 38,100 & & & & \\
\hline & Sample G333 & 39.000 & & & & \\
\hline & Sample G459 & 37,400 & & & & \\
\hline & Semple G460 & 47,300 & & & & \\
\hline & Sample G338 & 38,100 & & & & \\
\hline & Sample G341 & 37,700 & & & & \\
\hline & Sample G443 & 54,800 & & & & \\
\hline
\end{tabular}


WHC-SD-WM-ER-358 REV O

Table A-2. Tank 241-AP-102 Analytical Data: Phosphate

\begin{tabular}{|c|c|c|c|c|c|c|}
\hline Ansto & $\begin{array}{l}\text { uborotory } \\
\text { sumple }\end{array}$ & $\begin{array}{l}\text { Anshyct } \\
\text { opren. } \\
\text { hoph }\end{array}$ & 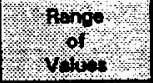 & Strtistica & 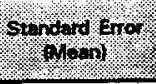 & אyolod \\
\hline Anion & & $\mu \mathrm{g} / \mathrm{mL}$ & $\mu g / m L$ & $\mu / m L$ & $\mu g / m L$ & kg \\
\hline \multirow[t]{19}{*}{$\mathrm{IC.PO}_{4}^{-3}$} & Stample G509 & 12,100 & \multirow{19}{*}{$\begin{array}{c}10,800 \\
t 0 \\
13,300\end{array}$} & \multirow[t]{19}{*}{11,600} & \multirow[t]{19}{*}{210} & \multirow[t]{19}{*}{48,500} \\
\hline & Semple G523 & 11,600 & & & & \\
\hline & Sample G477 & 12,200 & & & & \\
\hline & Sample G510 & 11,300 & & & & \\
\hline & Sample G511 & 11,200 & & & & \\
\hline & Sample G521 & 12,200 & & & & \\
\hline & Sample G527 & 11,300 & & & & \\
\hline & Sample G522 & 12,400 & & & & \\
\hline & Sample G515 & 11,900 & & & & \\
\hline & Sample G471 & 12,400 & & & & \\
\hline & Sample G516 & 11.200 & & & & \\
\hline & Sample G533 & 12,200 & & & & \\
\hline & Sample G534 & 11,900 & & & & \\
\hline & Sample G528 & 10,800 & & & & \\
\hline & Sample G517 & 11,500 & & & & \\
\hline & Sample G536 & 11,900 & & & & \\
\hline & Sample G529 & 11,300 & & & & \\
\hline & Sample G476 & 12,400 & & & & \\
\hline & Sample G470 & 13,300 & & & & \\
\hline
\end{tabular}


Table A-2. Tank 241-AP-102 Analytical Data: Suffate

\begin{tabular}{|c|c|c|c|c|c|c|}
\hline Mnshys & $\begin{array}{l}\text { Losorator } \\
\text { somplos }\end{array}$ & 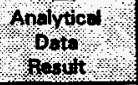 & P.p. & stristhe & 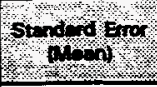 & $\begin{array}{l}\text { propetod } \\
\text { imphtory }\end{array}$ \\
\hline Anion & & $\mu \mathrm{g} / \mathrm{mL}$ & $\mu g / m L$ & $\mu \mathrm{g} / \mathrm{mL}$ & $\mu g / m L$ & kg \\
\hline \multirow[t]{19}{*}{ IC. $\mathrm{SO}_{4}{ }^{2-}$} & Sample G509 & $(4,810)$ & \multirow{19}{*}{$\begin{array}{c}3.710 \\
10 \\
4,850\end{array}$} & \multirow[t]{19}{*}{4,510} & \multirow[t]{19}{*}{89.9} & \multirow[t]{19}{*}{18,900} \\
\hline & Sampie G523 & $(4,580)$ & & & & \\
\hline & Semple 6477 & $(3,730)$ & & & & \\
\hline & Semple G510 & $(4,750)$ & & & & \\
\hline & Semple G511 & $(4.750)$ & & & & \\
\hline & Sample G521 & $(4,660)$ & & & & \\
\hline & Sample G527 & $(4,790)$ & & & & \\
\hline & Sample G522 & $(4,760)$ & & & & \\
\hline & Sample G515 & $(4,830)$ & & & & \\
\hline & Sample G471 & $(3,710)$ & & & & \\
\hline & Sample G516 & $(4,640)$ & & & & \\
\hline & Sample G533 & $(4,580)$ & & & & \\
\hline & Sample G534 & $(4,600)$ & & & & \\
\hline & Sample G528 & $(4,550)$ & & & & \\
\hline & Sample G517 & $(4,850)$ & & & & \\
\hline & Sample G536 & $(4,540)$ & & & & \\
\hline & Sample G529 & $(4,650)$ & & & & \\
\hline & Sample G476 & $(3,780)$ & & & & \\
\hline & Sample 6470 & $(3,910)$ & & & & \\
\hline
\end{tabular}


Table A-3. Tank 241-AP-102 Analytical Dats: Americium-241

\begin{tabular}{|c|c|c|c|c|c|c|}
\hline 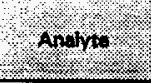 & Konotoly & Anvitod & 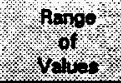 & Strifiod & 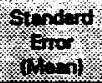 & 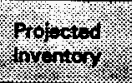 \\
\hline Radionuclide & & $\mu \mathrm{C} / \mathrm{mL}$ & $\mu \mathrm{Ci} / \mathrm{mL}$ & $\mu \mathrm{Ci} / \mathrm{mL}$ & $\mu \mathrm{Cl} / \mathrm{mL}$ & $\mathrm{Cl}$ \\
\hline \multirow{13}{*}{$\begin{array}{r}\text { APC/AEA. } \\
{ }^{241} \text { Am }\end{array}$} & Somple G342 & $3.26 E-04$ & \multirow{13}{*}{$\begin{array}{l}2.35 E-04 \\
\text { to } \\
8.49 E-04\end{array}$} & \multirow[t]{13}{*}{ 4.19E-04 } & \multirow[t]{13}{*}{$6.16 E-05$} & \multirow[t]{13}{*}{1.75} \\
\hline & Sample G348 & 2.38E-04 & & & & \\
\hline & Sample G349 & $4.76 \mathrm{E}-04$ & & & & \\
\hline & Sample 6352 & $4.58 E-04$ & & & & \\
\hline & Sample G353 & $4.89 E-04$ & & & & \\
\hline & Sample G358 & $8.49 E-04$ & & & & \\
\hline & Sample G359 & 7.19E-04 & & & & \\
\hline & Sample G363 & 2.35E-04 & & & & \\
\hline & Sample G364 & 2.45E-04 & & & & \\
\hline & Sample G459 & 4.38E-04 & & & & \\
\hline & Sample G460 & $3.74 \mathrm{E}-04$ & & & & \\
\hline & Sample G341 & $4.80 E-04$ & & & & \\
\hline & Sample G443 & $3.81 E-04$ & & & & \\
\hline
\end{tabular}


Table A-3. Tank 241-AP-102 Analytical Data: Antimony-125

\begin{tabular}{|c|c|c|c|c|c|c|}
\hline 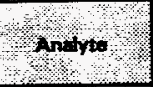 & 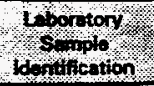 & 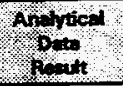 & 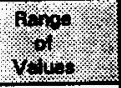 & 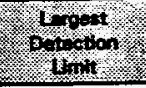 & (4) & 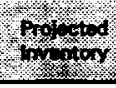 \\
\hline Radionuclide & & $\mu \mathrm{Ci} / \mathrm{mL}$ & $\mu \mathrm{Cl} / \mathrm{mL}$ & $\mu \mathrm{Ci} / \mathrm{mL}$ & $\mathrm{m} \mathrm{C} / \mathrm{mL}$ & $\boldsymbol{q}$ \\
\hline \multirow{19}{*}{$\underset{125 \text { Sb }}{\text { GEA. }}$} & Sample $\mathbf{G 3 4 2}$ & $<0.427$ & \multirow{19}{*}{$\begin{array}{c}<0.285 \\
\text { to } \\
<0.431\end{array}$} & \multirow[t]{19}{*}{$<0.431$} & \multirow[t]{19}{*}{$\mathbf{N} / \mathbf{A}$} & \multirow[t]{19}{*}{$<1,800$} \\
\hline & Semple 6449 & $<0.420$ & & & & \\
\hline & Sampla G450 & $<0.425$ & & & & \\
\hline & Sample G348 & $<0.418$ & & & & \\
\hline & Sample G349 & $<0.427$ & & & & \\
\hline & Sample $\mathbf{6 3 5 2}$ & $<0.291$ & & & & \\
\hline & Sample G453 & $<0.295$ & & & & \\
\hline & Sample G353 & $<0.417$ & & & & \\
\hline & Sample G358 & $<0.414$ & & & & \\
\hline & Sample G454 & $<0.295$ & & & & \\
\hline & Sample $\mathbf{G 3 5 9}$ & $<0.291$ & & & & \\
\hline & Sample 6363 & $<0.427$ & & & & \\
\hline & Sample G364 & $<0.414$ & & & & \\
\hline & Sample G333 & $<0.292$ & & & & \\
\hline & Sample G459 & $<0.288$ & & & & \\
\hline & Sample G460 & $<0.285$ & & & & \\
\hline & Sample G338 & $<0.293$ & & & & \\
\hline & Sample G341 & $<0.425$ & & & & \\
\hline & Sample G443 & $<0.431$ & & & & \\
\hline
\end{tabular}


Table A-3. Tank 241-AP-102 Analytical Data: Carbon-14

\begin{tabular}{|c|c|c|c|c|c|c|}
\hline Antrants & 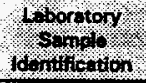 & $\mathrm{An}_{\mathrm{B}} \mathrm{hl}$ & $\begin{array}{l}\text { plos } \\
\text { pol }\end{array}$ & 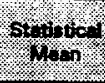 & 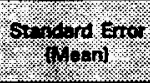 & 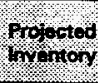 \\
\hline Radionuclide & & rCimL & $\mu \mathrm{Ci} / \mathrm{mL}$ & $\mathrm{MCl} / \mathrm{mL}$ & $1 \mathrm{Ci} / \mathrm{mL}$ & $\mathbf{C i}$ \\
\hline \multirow{12}{*}{$\begin{array}{l}\text { Lsc. } \\
{ }^{14} \mathrm{C}\end{array}$} & Sample $\mathbf{G 3 4 2}$ & $4.73 E-04$ & \multirow{12}{*}{$\begin{array}{c}4.34 E-04 \\
\text { to } \\
5.37 E-04\end{array}$} & \multirow[t]{12}{*}{ 4.99E-04 } & \multirow[t]{12}{*}{$1.56 \mathrm{E}-05$} & \multirow[t]{12}{*}{2.09} \\
\hline & Sample G348 & 5.18E-04 & & & & \\
\hline & Sample G349 & $5.06 E-04$ & & & & \\
\hline & Sample G352 & (5.20E-0.4) & & & & \\
\hline & Semple G353 & $(4.78 E-04)$ & & & & \\
\hline & Sample G358 & (4.91E-0.4) & & & & \\
\hline & Sample G359 & 5.20E-04 & & & & \\
\hline & Sample G363 & (4.35E-0.4) & & & & \\
\hline & Sample G364 & 5.23E-04 & & & & \\
\hline & Sample G459 & (5.37E-04) & & & & \\
\hline & Sample G460 & $4.81 E-04$ & & & & \\
\hline & Sample G341 & $5.16 \mathrm{E}-04$ & & & & \\
\hline
\end{tabular}

Table A-3. Tank 241-AP-102 Analytical Data: Cerium/Praesedymium-144

\begin{tabular}{|c|c|c|c|c|c|c|}
\hline Analyte & $\begin{array}{l}\text { Leboratory } \\
\text { Sample } \\
\text { Identification }\end{array}$ & $\begin{array}{c}\text { Analvtical } \\
\text { Date } \\
\text { Resit }\end{array}$ & $\begin{array}{l}\text { Range } \\
\text { of } \\
\text { Values }\end{array}$ & $\begin{array}{l}\text { Largest } \\
\text { Detection } \\
\text { Limit }\end{array}$ & $\begin{array}{c}\text { Standard Error } \\
\text { (Nean) }\end{array}$ & $\begin{array}{l}\text { Projected } \\
\text { Inventory }\end{array}$ \\
\hline Radionuclide & & $\mu \mathrm{Ci} / \mathrm{mL}$ & $\mu \mathrm{Ci} / \mathrm{mL}$ & $\mu \mathrm{Ci} / \mathrm{mL}$ & $\mu \mathrm{Ci} / \mathrm{mL}$ & $\mathrm{Ci}$ \\
\hline \multirow{13}{*}{$\begin{array}{l}\text { GEA. } \\
{ }^{144} \mathrm{Ce} / \mathrm{Pr}\end{array}$} & Sample G342 & $<1.02$ & \multirow{13}{*}{$\begin{array}{c}<0.522 \\
\text { to } \\
<1.03\end{array}$} & \multirow[t]{13}{*}{$<1.03$} & \multirow[t]{13}{*}{ N/A } & \multirow[t]{13}{*}{4,310} \\
\hline & Sample G348 & $<0.997$ & & & & \\
\hline & Sample G352 & $<0.535$ & & & & \\
\hline & Sample G349 & $<1.03$ & & & & \\
\hline & Sample G358 & $<0.983$ & & & & \\
\hline & Sample G353 & $<0.996$ & & & & \\
\hline & Sample G359 & $<0.533$ & & & & \\
\hline & Sample G363 & $<1.02$ & & & & \\
\hline & Sample G364 & $<0.979$ & & & & \\
\hline & Sample $\mathbf{6 4 5 9}$ & $<0.526$ & & & & \\
\hline & Sample G460 & $<0.522$ & & & & \\
\hline & Sample G341 & $<1.02$ & & & & \\
\hline & Sample 6443 & $<1.03$ & & & & \\
\hline
\end{tabular}


WHC-SD-WM-ER-358 REV O

Table A-3. Tank 241-AP-102 Analytical Data: Cesium-134

\begin{tabular}{|c|c|c|c|c|c|c|}
\hline $\mathrm{Ap}^{\mathrm{N}} \mathrm{ne}$ & 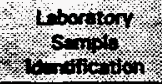 & 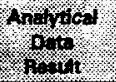 & 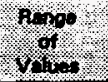 & patootons & 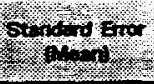 & orotod \\
\hline Radionuclide & & $\mu \mathrm{Cl} / \mathrm{mL}$ & $\mu \mathrm{Cl} / \mathrm{mL}$ & $\mu \mathrm{CH} / \mathrm{ml}$ & $\mu$ OthL & C \\
\hline \multirow{19}{*}{$\begin{array}{l}\text { GEA. } \\
{ }^{134} \mathrm{Cs}\end{array}$} & Sarnple G342 & $<0.0280$ & \multirow{19}{*}{$\begin{array}{c}<0.0147 \\
t 0 \\
<0.0298\end{array}$} & \multirow[t]{19}{*}{$<0.0298$} & \multirow[t]{19}{*}{ N/A } & \multirow[t]{19}{*}{$<125$} \\
\hline & Semple G449 & $<0.0285$ & & & & \\
\hline & Semple 6450 & $<0.0272$ & & & & \\
\hline & Sample G348 & $<0.0295$ & & & & \\
\hline & Sample G349 & $<0.0285$ & & & & \\
\hline & Semple $\mathbf{6 3 5 2}$ & $<0.0156$ & & & & \\
\hline & Sample G453 & $<0.0159$ & & & & \\
\hline & Sample G353 & $<0.0289$ & & & & \\
\hline & Sample G358 & $<0.0270$ & & & & \\
\hline & Sample G454 & $<0.0158$ & & & & \\
\hline & Sample G359 & $<0.0159$ & & & & \\
\hline & Sample G363 & $<0.0254$ & & & & \\
\hline & Semple G364 & $<0.0255$ & & & & \\
\hline & Sample G333 & $<0.0162$ & & & & \\
\hline & Sample G459 & $<0.0150$ & & & & \\
\hline & Sample G460 & $<0.0148$ & & & & \\
\hline & Sample G338 & $<0.0147$ & & & & \\
\hline & Sample G341 & $<0.0214$ & & & & \\
\hline & Sample G443 & $<0.0298$ & & & & \\
\hline
\end{tabular}


WHC-SD-WM-ER-358 REV O

Table A-3. Tank 241-AP-102 Anahtical Data: Cesium-137

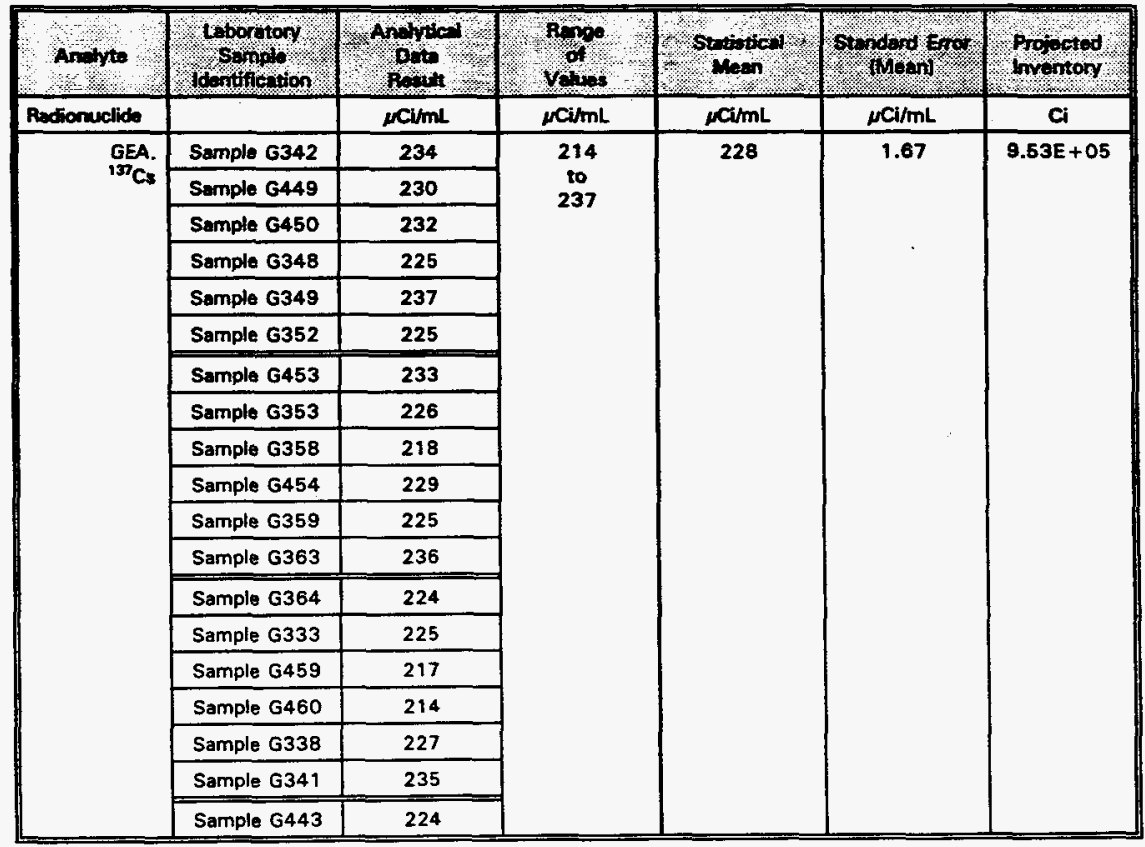


WHC-SD-WM-ER-358 REV 0

Table A-3. Tonk 241-AP-102 Analytical Data: Cobalt-60

\begin{tabular}{|c|c|c|c|c|c|c|}
\hline Haralfo & $\begin{array}{c}\text { Qbortory } \\
\text { Somple }\end{array}$ & 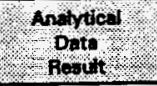 & $\begin{array}{l}\mathrm{Ranpe} \\
\mathrm{Vhr}\end{array}$ & $\begin{array}{l}\text { sinple } \\
\text { seps }\end{array}$ & 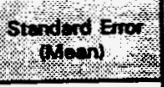 & propets \\
\hline Redionuclide & & $\mu \mathrm{Cl} / \mathrm{mL}$ & $\mu \mathrm{Ci} / \mathrm{mL}$ & $\mu \mathrm{Ci} / \mathrm{mL}$ & $\mu \mathrm{Ci} / \mathrm{mL}$ & $\mathrm{Ci}$ \\
\hline \multirow[t]{19}{*}{ GEA. ${ }^{\circ 0} \mathrm{Co}$} & Sarnple G342 & $<0.0189$ & \multirow{19}{*}{$\begin{array}{c}<0.0110 \\
\text { to } \\
0.0809\end{array}$} & \multirow[t]{19}{*}{0.0763} & \multirow[t]{19}{*}{ N/A } & \multirow[t]{19}{*}{319} \\
\hline & Sample G449 & $<0.0181$ & & & & \\
\hline & Sample G450 & $<0.0157$ & & & & \\
\hline & Semple G348 & $<0.0163$ & & & & \\
\hline & Semplo G349 & $<0.0169$ & & & & \\
\hline & Sample 6352 & $<0.0123$ & & & & \\
\hline & Sample $\mathbf{6 4 5 3}$ & $<0.0117$ & & & & \\
\hline & Sample $\mathbf{6 3 5 3}$ & 0.0717 & & & & \\
\hline & Sample G358 & 0.0809 & & & & \\
\hline & Sample G454 & $<0.0138$ & & & & \\
\hline & Sample G359 & $<0.0122$ & & & & \\
\hline & Sample G363 & $<0.0197$ & & & & \\
\hline & Sample G364 & $<0.0181$ & & & & \\
\hline & Sample G333 & $<0.0110$ & & & & \\
\hline & Sample G459 & $<0.0130$ & & & & \\
\hline & Sample G460 & $<0.0136$ & & & & \\
\hline & Sample 6338 & $<0.0123$ & & & & \\
\hline & Sample G341 & $<0.0169$ & & & & \\
\hline & Sample 6443 & $<0.0207$ & & & & \\
\hline
\end{tabular}


Table A-3. Tank 241-AP-102 Analytical Data: Curium-244

\begin{tabular}{|c|c|c|c|c|c|c|}
\hline (1) An & 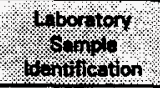 & $\begin{array}{l}\text { Anthtical } \\
\text { Dota } \\
\text { Rosilt }\end{array}$ & $\begin{array}{l}\text { Rorpe } \\
\text { nols }\end{array}$ & Lepest & Stropord Eror & $\begin{array}{l}\text { Projocted } \\
\text { Hrentory }\end{array}$ \\
\hline Radionuclide & & $\mu \mathrm{Ci} / \mathrm{mL}$ & $\mu \mathrm{Cl} / \mathrm{mL}$ & rcimL & $\mu \mathrm{Ci} / \mathrm{mL}$ & a \\
\hline \multirow[t]{13}{*}{$\mathrm{AEA} \cdot{ }^{244} \mathrm{Cm}$} & Sample G342 & $<$ 6.37E-05 & \multirow{13}{*}{$\begin{array}{c}<2.55 E-05 \\
\text { to } \\
<6.37 E-05\end{array}$} & \multirow[t]{13}{*}{$<6,37 E-05$} & \multirow[t]{13}{*}{$\mathbf{N} / \mathbf{A}$} & \multirow[t]{13}{*}{$<0.266$} \\
\hline & Sample G348 & $<6.37 E-05$ & & & & \\
\hline & Sample G352 & $<6.37 E-05$ & & & & \\
\hline & Sample G349 & $<6.37 E-05$ & & & & \\
\hline & Sample G358 & $<6.37 \mathrm{E}-05$ & & & & \\
\hline & Sample G353 & $<6.37 \mathrm{E}-05$ & & & & \\
\hline & Sample $\mathbf{6 3 5 9}$ & $<6.37 \mathrm{E}-05$ & & & & \\
\hline & Sample G363 & $<6.37$ E-05 & & & & \\
\hline & Sample G364 & $<6.37 E-05$ & & & & \\
\hline & Sample G459 & $<6.37$ E-05 & & & & \\
\hline & Sample G460 & $<6.37 E-05$ & & & & \\
\hline & Sample G341 & $<6.37 \mathrm{E}-05$ & & & & \\
\hline & Sample $\mathbf{G 4 4 3}$ & $<2.55 \mathrm{E}-05$ & & & & \\
\hline
\end{tabular}

Table A-3. Tank 241-AP-102 Analytical Data: lodine-129

\begin{tabular}{|r|c|c|c|c|c|c|}
\hline Anatyte & $\begin{array}{c}\text { Laboratory } \\
\text { Sample } \\
\text { Identification }\end{array}$ & $\begin{array}{c}\text { Analytical } \\
\text { Data } \\
\text { Result }\end{array}$ & $\begin{array}{c}\text { Range } \\
\text { of } \\
\text { Values }\end{array}$ & $\begin{array}{c}\text { Largest } \\
\text { Detection Limit }\end{array}$ & $\begin{array}{c}\text { Standard Error } \\
\text { (Mean }\end{array}$ & $\begin{array}{c}\text { Projected } \\
\text { Imrentory }\end{array}$ \\
\hline Radionuclide & & $\mu \mathrm{Ci} / \mathrm{mL}$ & $\mu \mathrm{Ci} / \mathrm{mL}$ & $\mu \mathrm{Ci} / \mathrm{mL}$ & $\mu \mathrm{Ci} / \mathrm{mL}$ & $\mathrm{Ci}$ \\
\hline $\begin{array}{r}\text { GEA. } \\
129\end{array}$ & Sample G443 & $<3.70 \mathrm{E}-05$ & $\mathrm{~N} / \mathrm{A}$ & $<3.70 \mathrm{OE}-05$ & $\mathrm{~N} / \mathrm{A}$ & $<0.155$ \\
\hline
\end{tabular}


Table A-3. Tank 241-AP-102 Analyticad Data: Neptunium-237

\begin{tabular}{|c|c|c|c|c|c|c|}
\hline Anohts & Soboretol & $\begin{array}{l}\text { Andificd } \\
\text { phts }\end{array}$ & 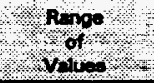 & ofocts & 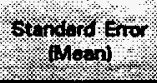 & Proporod \\
\hline Radionuclide & & $\mu \mathrm{Ci} / \mathrm{mL}$ & $\mathrm{cCI} / \mathrm{mL}$ & - $\mu \mathrm{Ci} / \mathrm{mL}$ & $\mu \mathrm{Ci} / \mathrm{mL}$ & $\boldsymbol{c}$ \\
\hline \multirow{12}{*}{$\begin{array}{l}\text { APC. } \\
23 \mathrm{NP}_{\mathrm{Np}}\end{array}$} & Sample G342 & $<0.001$ & \multirow{12}{*}{$\begin{array}{c}<2.81 E-04 \\
\text { to } \\
<0.001\end{array}$} & \multirow[t]{12}{*}{$<0.001$} & \multirow[t]{12}{*}{$\mathbf{N} / \mathbf{A}$} & \multirow[t]{12}{*}{$<4.18$} \\
\hline & Sample G348 & $<3.89 E-04$ & & & & \\
\hline & Semple G349 & $<3.89 \mathrm{E}-04$ & & & & \\
\hline & Sample $\mathbf{G 3 5 2}$ & $<3.89 E-04$ & & & & \\
\hline & Sample 6353 & $<3.89 \mathrm{E}-04$ & & & & \\
\hline & Sample $\mathbf{G 3 5 8}$ & $<4.65 \mathrm{E}-04$ & & & & \\
\hline & Semple $\mathbf{6 3 5 9}$ & $<3.89 E-04$ & & & & \\
\hline & Sample G363 & $<4.32 E-04$ & & & & \\
\hline & Sample G364 & $<2.81$ E-04 & & & & \\
\hline & Sample G459 & $<4.32 \mathrm{E}-04$ & & & & \\
\hline & Sample G460 & $<4.32 \mathrm{E}-04$ & & & & \\
\hline & Sample G341 & $<4.32$ E.04 & & & & \\
\hline
\end{tabular}


WHC-SD-WM-ER-358 REV O

Table A-3. Tank 241-AP-102 Andytical Data: Niobium-94

\begin{tabular}{|c|c|c|c|c|c|c|}
\hline 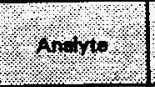 & 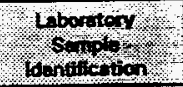 & 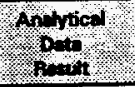 & Monos & 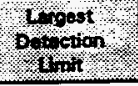 & 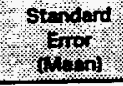 & Projented \\
\hline Radionuclide & & $\mu \mathrm{cimL}$ & $\mu \mathrm{Ci} / \mathrm{mL}$ & $\mu \mathrm{C} / \mathrm{mL}$ & $\mu \mathrm{Ci} / \mathrm{mL}$ & $\mathrm{Ci}$ \\
\hline \multirow{19}{*}{$\begin{array}{l}\text { GEA. } \\
\text { O4Nb }\end{array}$} & Semple G342 & $<0.0246$ & \multirow{19}{*}{$\begin{array}{c}<0.0146 \\
<0.0257\end{array}$} & \multirow[t]{19}{*}{$<0.0257$} & \multirow[t]{19}{*}{ N/A } & \multirow[t]{19}{*}{$<107$} \\
\hline & Sample G449 & $<0.0237$ & & & & \\
\hline & Sample G450 & $<0.0257$ & & & & \\
\hline & Sample 6348 & $<0.0235$ & & & & \\
\hline & Sample 6349 & $<0.0236$ & & & & \\
\hline & Sample G352 & $<0.0152$ & & & & \\
\hline & Sample G453 & $<0.0161$ & & & & \\
\hline & Sample $\mathbf{6 3 5 3}$ & $<0.0238$ & & & & \\
\hline & Sample 6358 & $<0.0225$ & & & & \\
\hline & Sample G454 & $<0.0162$ & & & & \\
\hline & Sample G359 & $<0.0151$ & & & & \\
\hline & Sample G363 & $<0.0241$ & & & & \\
\hline & Sample G364 & $<0.0236$ & & & & \\
\hline & Sample G333 & $<0.0157$ & & & & \\
\hline & Sample G459 & $<0.0146$ & & & & \\
\hline & Sample 6460 & $<0.0161$ & & & & \\
\hline & Sample $\mathbf{6 3 3 8}$ & $<0.0150$ & & & & \\
\hline & Sample $\mathbf{6 3 4 1}$ & $<0.0246$ & & & & \\
\hline & Sample G443 & $<0.0246$ & & & & \\
\hline
\end{tabular}


WHC-SD-WM-ER-358 REV O

Table A-3. Tank 241-AP-102 Analytical Data: Plutorium-238

\begin{tabular}{|c|c|c|c|c|c|c|}
\hline Andrts & 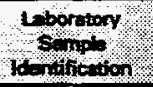 & $\begin{array}{l}\text { Anaytod } \\
\text { sold }\end{array}$ & $\begin{array}{l}\text { funpe } \\
\text { yoluss }\end{array}$ & $\begin{array}{l}\text { Lervest } \\
\text { Detection } \\
\text { Luthl }\end{array}$ & 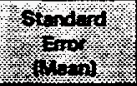 & Prow \\
\hline Radionuclide & & $\mu \mathrm{Ci} / \mathrm{mL}$ & $\mu \mathrm{Ci} / \mathrm{mL}$ & $\mu \mathrm{C} / \mathrm{mL}$ & $\mu \mathrm{csimL}$ & 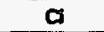 \\
\hline \multirow{12}{*}{$\begin{array}{r}\text { APC/AEA. } \\
23 \mathrm{Pu}^{2}\end{array}$} & Sample G342 & $<1.00 E-04$ & \multirow{12}{*}{$\begin{array}{l}<9.64 E-05 \\
\text { to } \\
<1.63 E-04\end{array}$} & \multirow[t]{12}{*}{$<1.63 E-04$} & \multirow[t]{12}{*}{ N/A } & \multirow[t]{12}{*}{$<0.681$} \\
\hline & Sample G348 & $<9.64 E-05$ & & & & \\
\hline & Semple 6349 & $<9.87 E-05$ & & & & \\
\hline & Sample G352 & $<1.11 E-04$ & & & & \\
\hline & Sample G353 & $<1.23 E-04$ & & & & \\
\hline & Semple G358 & $<1.63 \mathrm{E}-04$ & & & & \\
\hline & Sample G359 & $<1.50 \mathrm{E}-04$ & & & & \\
\hline & Sample G363 & $<9.88 \mathrm{E}-05$ & & & & \\
\hline & Semple G364 & $<1.22 \mathrm{E}-04$ & & & & \\
\hline & Sample G459 & $<1.01 \mathrm{E}-04$ & & & & \\
\hline & Sample 6460 & $<1.02 \mathrm{E}-04$ & & & & \\
\hline & Sample G341 & $<1.08 \mathrm{E}-04$ & & & & \\
\hline
\end{tabular}

Table A-3. Tank 241-AP-102 Analytical Data: Plutonium-239/240

\begin{tabular}{|c|c|c|c|c|c|c|}
\hline Analyte & $\begin{array}{l}\text { Laboratory } \\
\text { Sample } \\
\text { dentification }\end{array}$ & $\begin{array}{l}\text { Analytical } \\
\text { Data } \\
\text { Resutt }\end{array}$ & $\begin{array}{c}\text { Range } \\
\text { of } \\
\text { Values }\end{array}$ & $\begin{array}{l}\text { Largest } \\
\text { Detection } \\
\text { Limit }\end{array}$ & $\begin{array}{l}\text { Standard } \\
\text { Error. } \\
\text { (Mear) }\end{array}$ & $\begin{array}{l}\text { Projected } \\
\text { Irventory }\end{array}$ \\
\hline Radionuclide & & $\mu \mathrm{Ci} / \mathrm{mL}$ & $\mu \mathrm{Ci} / \mathrm{mL}$ & $\mu \mathrm{Ci} / \mathrm{mL}$ & $\mu \mathrm{Ci} / \mathrm{mL}$ & $\mathrm{Ci}$ \\
\hline \multirow{12}{*}{$\begin{array}{l}\text { APC/AEA. } \\
239 / 2409 \mathrm{Pu}\end{array}$} & Sample G342 & $<6.72 \mathrm{E}-\mathrm{O} 5$ & \multirow{12}{*}{$\begin{array}{c}<6.64 \mathrm{E}-05 \\
\text { to } \\
<7.48 \mathrm{E}-05\end{array}$} & \multirow[t]{12}{*}{$<7.48 E-05$} & \multirow[t]{12}{*}{ N/A } & \multirow[t]{12}{*}{$<0.313$} \\
\hline & Sample G348 & $<6.96 \mathrm{E}-05$ & & & & \\
\hline & Sample G349 & $<6.96 \mathrm{E}-05$ & & & & \\
\hline & Sample $\mathbf{G 3 5 2}$ & $<6.64 \mathrm{E}-05$ & & & & \\
\hline & Sample G353 & $<6.74 \mathrm{E}-05$ & & & & \\
\hline & Sample G358 & $<6.82 E-05$ & & & & \\
\hline & Sample G359 & $<6.81 \mathrm{E}-05$ & & & & \\
\hline & Sample G363 & $<6.86 \mathrm{E}-05$ & & & & \\
\hline & Sample G364 & $<6.99 E-05$ & & & & \\
\hline & Sampie G459 & $<6.90-05$ & & & & \\
\hline & Sample 6460 & $<6.86 \mathrm{E}-05$ & & & & \\
\hline & Samp: $=341$ & $<7.48 \mathrm{E}-05$ & & & & \\
\hline
\end{tabular}


Table A-3. Tank 241-AP-102 Analytical Data: Rutherium/Pthodium-106

\begin{tabular}{|c|c|c|c|c|c|c|}
\hline Antwa & 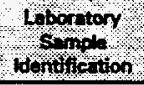 & $\mathrm{Anth}_{x+1}$ & 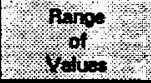 & 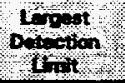 & 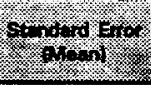 & Whorom \\
\hline Radionuclide & & $\mu \mathrm{CimL}$ & $\mu \mathrm{Ci} / \mathrm{mL}$ & $\mu \mathrm{CS} / \mathrm{mL}$ & $\mu \mathrm{Cl} / \mathrm{mL}$ & Ci \\
\hline \multirow{19}{*}{$\begin{array}{r}\text { GEA. } \\
{ }^{10 c_{\text {RuRh }}}\end{array}$} & Sample $\mathbf{G 3 4 2}$ & $<1.35$ & \multirow{19}{*}{$\begin{array}{l}<1.01 \\
\text { to } \\
<1.39\end{array}$} & \multirow[t]{19}{*}{$<1.39$} & \multirow[t]{19}{*}{$\mathbf{N} / \mathbf{A}$} & \multirow[t]{19}{*}{$<5,810$} \\
\hline & Sample G449 & $<1.33$ & & & & \\
\hline & Sample G450 & $<1.34$ & & & & \\
\hline & Sample 6348 & $<1.35$ & & & & \\
\hline & Sample G349 & $<1.39$ & & & & \\
\hline & Sample $\mathbf{6 3 5 2}$ & $<1.03$ & & & & \\
\hline & Sample G453 & $<1.04$ & & & & \\
\hline & Sample G353 & $<1.33$ & & & & \\
\hline & Sample G358 & $<1.32$ & & & & \\
\hline & Sample G454 & $<1.04$ & & & & \\
\hline & Semple 6359 & $<1.03$ & & & & \\
\hline & Sample G363 & $<1.39$ & & & & \\
\hline & Sample G364 & $<1.32$ & & & & \\
\hline & Sample G333 & $<1.03$ & & & & \\
\hline & Sample G459 & $<1.01$ & & & & \\
\hline & Sample G460 & $<1.01$ & & & & \\
\hline & Sample G338 & $<1.03$ & & & & \\
\hline & Sample G341 & $<1.39$ & & & & \\
\hline & Sample G443 & $<1.38$ & & & & \\
\hline
\end{tabular}


Table A-3. Tank 241-AP-102 Analytical Data: Strontium-90

\begin{tabular}{|c|c|c|c|c|c|c|}
\hline Ahlyte & $\begin{array}{l}\text { Laboratory } \\
\text { Somple } \\
\text { dentification. }\end{array}$ & $\begin{array}{l}\text { Apoptict } \\
\text { prowat }\end{array}$ & Penre & $\begin{array}{l}\text { Sthotcd } \\
\text { Men }\end{array}$ & srminderor & Propoled \\
\hline Radionuclide & & $\mu \mathrm{Ci} / \mathrm{mL}$ & $\mu \mathrm{Cl} / \mathrm{mL}$ & $\mu \mathrm{ci} / \mathrm{mL}$ & $\mu \mathrm{climL}$ & $\mathrm{Ci}$ \\
\hline \multirow{13}{*}{$\underset{\mathrm{SOS}}{\mathrm{BPC}}$} & Sample G342 & $(1.45)$ & \multirow{13}{*}{$\begin{array}{l}1.37 \\
\text { to } \\
1.49\end{array}$} & \multirow[t]{13}{*}{1.44} & \multirow[t]{13}{*}{0.0174} & \multirow[t]{13}{*}{6,020} \\
\hline & Semple G348 & $(1.41)$ & & & & \\
\hline & Sample G349 & $(1.48)$ & & & & \\
\hline & Sample G352 & (1.37) & & & & \\
\hline & Sample G353 & (1.39) & & & & \\
\hline & Sample 6358 & $(1.42)$ & & & & \\
\hline & Sample G359 & $(1,43)$ & & & & \\
\hline & Sample G363 & $(1.39)$ & & & & \\
\hline & Sample G364 & $(1.42)$ & & & & \\
\hline & Sample G459 & $(1.41)$ & & & & \\
\hline & Sample G460 & $(1.40)$ & & & & \\
\hline & Sample G341 & (1.39) & & & & \\
\hline & Sample G443 & $(1.49)$ & & & & \\
\hline
\end{tabular}

Table A-3. Tank 241-AP-102 Analytical Data: Technetium-99

\begin{tabular}{|c|c|c|c|c|c|c|}
\hline Analyte & $\begin{array}{c}\text { Laboratory } \\
\text { Sample } \\
\text { Identification }\end{array}$ & $\begin{array}{l}\text { Anahytical } \\
\text { Data } \\
\text { Result } \\
\end{array}$ & $\begin{array}{c}\text { Range } \\
\text { of } \\
\text { Velues } \\
\end{array}$ & $\begin{array}{c}\text { Statistical } \\
\text { Mean }\end{array}$ & $\begin{array}{l}\text { Standard } \\
\text { Error } \\
\text { (Mean) }\end{array}$ & $\begin{array}{l}\text { Projected } \\
\text { Impentory }\end{array}$ \\
\hline Radionuclide & & $\mu \mathrm{Ci} / \mathrm{mL}$ & $\mu \mathrm{Ci} / \mathrm{mL}$ & $\mu \mathrm{Ci} / \mathrm{mL}$ & $\mu \mathrm{CimnL}$ & $\mathrm{Ci}$ \\
\hline \multirow{13}{*}{$\begin{array}{l}\text { LSC. } \\
{ }^{99} \mathrm{TC}\end{array}$} & Sample G342 & $(0.0899)$ & \multirow{13}{*}{$\begin{array}{c}0.0489 \\
\text { to } \\
0.0954\end{array}$} & \multirow[t]{13}{*}{0.0856} & \multirow[t]{13}{*}{0.00204} & \multirow[t]{13}{*}{358} \\
\hline & Sample G348 & $(0.0884)$ & & & & \\
\hline & Sample G349 & 10.08901 & & & & \\
\hline & Sample G352 & $(0.0839)$ & & & & \\
\hline & Sample G353 & $(0.0521)$ & & & & \\
\hline & Sample G358 & $(0.0489)$ & & & & \\
\hline & Sample G359 & $(0.0537)$ & & & & \\
\hline & Sample G363 & $(0.0853)$ & & & & \\
\hline & Sample G364 & $(0.0859)$ & & & & \\
\hline & Sample G459 & $(0.0824)$ & & & & \\
\hline & Sample G460 & $(0.0691)$ & & & & \\
\hline & Sample G341 & $(0.0899)$ & & & & \\
\hline & Sample G443 & $(0.0954)$ & & & & \\
\hline
\end{tabular}


WHC-SD-WM-ER-358 REV O

Table A-3. Tank 241-AP-102 Analytical Date: Tritium

\begin{tabular}{|c|c|c|c|c|c|c|}
\hline Antro & Wobotory & 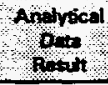 & pars & Strtistied & $\begin{array}{l}\text { Sepdord } \\
\text { Enot } \\
\text { istin }\end{array}$ & Projoctod \\
\hline Radionuclide & & rCinmL. & $\mu \mathrm{Ci} / \mathrm{mL}$ & $\mu \mathrm{Ci} / \mathrm{mL}$ & $\mathrm{mCi} / \mathrm{mL}$ & Ci \\
\hline $\operatorname{LSC}^{3} \mathrm{H}$ & Sample G443 & 0.0420 & $N / A$ & $\mathbf{N} / \mathbf{A}$ & $\mathbf{N} / \mathbf{A}$ & N/A \\
\hline
\end{tabular}

Toble A-4. Tank 241-AP-102 Analytical Data: Organic Complexant Analyses (page 1 of 2)

\begin{tabular}{|c|c|c|c|c|c|c|}
\hline Analyte & $\begin{array}{c}\text { Laboratory } \\
\text { Sample } \\
\text { Identification }\end{array}$ & $\begin{array}{c}\text { Analytical } \\
\text { Data } \\
\text { Result }\end{array}$ & $\begin{array}{l}\text { Annge } \\
\text { of } \\
\text { values }\end{array}$ & Mean & $\begin{array}{c}\text { Standard Error } \\
\text { (Mean) }\end{array}$ & $\begin{array}{l}\text { Projected } \\
\text { Irventory }\end{array}$ \\
\hline $\begin{array}{l}\text { Organic } \\
\text { Complexant }\end{array}$ & & $\mathrm{mg} / \mathrm{L}$ & $\mathrm{mg} / \mathrm{L}$ & $m g / L$ & $m g / L$ & kg \\
\hline \multirow[t]{7}{*}{ HPLC.Citrate } & Sample 6300 & $(570)$ & \multirow[t]{7}{*}{415 to 600} & \multirow[t]{7}{*}{515} & \multirow[t]{7}{*}{ N/A } & \multirow[t]{7}{*}{2.15} \\
\hline & Sample G304 & $(600)$ & & & & \\
\hline & Sample G312 & $(560)$ & & & & \\
\hline & Sample G314 & (545) & & & & \\
\hline & Sample 6316 & $(425)$ & & & & \\
\hline & Sample G320 & $(415)$ & & & & \\
\hline & Sample G321 & $(490)$ & & & & \\
\hline \multirow[t]{7}{*}{ HPLC.EDTA } & Sample 6300 & 450 & \multirow[t]{7}{*}{450 to 625} & \multirow[t]{7}{*}{519} & \multirow[t]{7}{*}{$N / A$} & \multirow[t]{7}{*}{2.17} \\
\hline & Sample G304 & 520 & & & & \\
\hline & Semple G312 & 500 & & & & \\
\hline & Sample G314 & 500 & & & & \\
\hline & Sample G316 & 505 & & & & \\
\hline & Sample G320 & 530 & & & & \\
\hline & Sample 6321 & (625) & & & & \\
\hline \multirow[t]{7}{*}{ HPLC.HEDTA } & Sample 6300 & 93 & \multirow[t]{7}{*}{80 to 140} & \multirow[t]{7}{*}{110} & \multirow[t]{7}{*}{ N/A } & \multirow[t]{7}{*}{0.460} \\
\hline & Sample G304 & $(140)$ & & & & \\
\hline & Sample G312 & (135) & & & & \\
\hline & Sample $\mathrm{G} 314$ & $(80)$ & & & & \\
\hline & Sample G316 & 85 & & & & \\
\hline & Sample G320 & 87 & & & & \\
\hline & Sampie 6321 & $\{130\}$ & & & & \\
\hline
\end{tabular}


Table A-4. Tanik 241-AP-102 Analytical Data: Organic Complexant Analyses. (page 2 of 2)

\begin{tabular}{|c|c|c|c|c|c|c|}
\hline (Ansylo, & 1. & $\begin{array}{l}\text { Aolytod } \\
\text { Botal } \\
\text { host }\end{array}$ & $\begin{array}{l}\text { penses } \\
\text { of } \\
\text { pentes }\end{array}$ & Simpte. & Stondard Eror & Propeted \\
\hline $\begin{array}{l}\text { Organic } \\
\text { Complexant }\end{array}$ & & $m g h$ & $m g h$ & $\mathrm{mg} / \mathrm{h}$ & $\mathrm{mgl}$ & kg \\
\hline \multirow[t]{7}{*}{ K. Gycolate } & Sample G300 & 1100 & \multirow[t]{7}{*}{ N/A } & \multirow[t]{7}{*}{1,100} & \multirow[t]{7}{*}{ N/A } & \multirow[t]{7}{*}{4,600} \\
\hline & Semple G304 & 1100 & & & & \\
\hline & Semple G312 & 1100 & & & & \\
\hline & Semple G314 & 1100 & & & & \\
\hline & Sample G316 & 1100 & & & & \\
\hline & Semple G320 & 1500 & & & & \\
\hline & Sample G321 & 1100 & & & & \\
\hline \multirow[t]{7}{*}{ IC. Oxalate } & Sample 6300 & 800 & \multirow{7}{*}{$\begin{array}{l}700 \\
\text { to } \\
800\end{array}$} & \multirow[t]{7}{*}{760} & \multirow[t]{7}{*}{ N/A } & \multirow[t]{7}{*}{3,180} \\
\hline & Semple G304 & 800 & & & & \\
\hline & Sample G312 & 800 & & & & \\
\hline & Sample 6314 & 700 & & & & \\
\hline & Sample G316 & 700 & & & & \\
\hline & Semple G320 & 750 & & & & \\
\hline & Sample G321 & 800 & & & & \\
\hline
\end{tabular}

Table A-5. Tank 241-AP-102 Analytical Data: Percent Water

\begin{tabular}{|c|c|c|c|c|c|}
\hline Analyte & $\begin{array}{c}\text { Labpratory } \\
\text { Sample } \\
\text { Identification }\end{array}$ & $\begin{array}{c}\text { Analytical } \\
\text { Data } \\
\text { Result }\end{array}$ & $\begin{array}{c}\text { Range } \\
\text { of } \\
\text { Vakues }\end{array}$ & Statistical Mean & $\begin{array}{c}\text { Standard Errot } \\
\text { (Mean) }\end{array}$ \\
\hline $\begin{array}{l}\text { Physical } \\
\text { Property }\end{array}$ & & $w \%$ & $w t \%$ & $w t \%$ & \\
\hline \multirow{13}{*}{$\% \mathrm{H}_{2} \mathrm{O}$} & Sample G342 & $(74.6)$ & \multirow{13}{*}{$\begin{array}{c}74.1 \\
\text { to } \\
75.5\end{array}$} & \multirow[t]{13}{*}{75.0} & \multirow[t]{13}{*}{0.144} \\
\hline & Sample G348 & $(75.4)$ & & & \\
\hline & Sample G349 & (75.3) & & & \\
\hline & Sample 6352 & $(75.0)$ & & & \\
\hline & Sampie G353 & $(75.4)$ & & & \\
\hline & Sample G358 & $(75.4)$ & & & \\
\hline & Sample G359 & $(75.4\}$ & & & \\
\hline & Sample G363 & $(74.7)$ & & & \\
\hline & Sample $\mathbf{G 3 6 4}$ & $(74.6)$ & & & \\
\hline & Sample G459 & $(74.1)$ & & & \\
\hline & Sample G460 & $(75.5)$ & & & \\
\hline & Sample G341 & $(75.3)$ & & & \\
\hline & Sample G443 & $\{74.21$ & & & \\
\hline
\end{tabular}


WHC-SD-WM-ER-358 REV O

Table A-5. Tenk 241-AP-102 Analytical Data: Specific Gravity

\begin{tabular}{|c|c|c|c|c|c|}
\hline $\mathrm{Andvte}$ & Whorton & 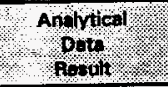 & 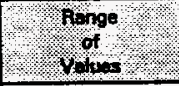 & Stallowol wom & Standard Enor \\
\hline \multicolumn{6}{|l|}{$\begin{array}{l}\text { Physical } \\
\text { Property }\end{array}$} \\
\hline \multirow{13}{*}{$\begin{array}{r}\text { Specific } \\
\text { Gravity }\end{array}$} & Sample G342 & $(1.20)$ & \multirow{13}{*}{$\begin{array}{l}1.19 \\
\text { to } \\
1.21\end{array}$} & \multirow[t]{13}{*}{1.20} & \multirow[t]{13}{*}{0.00167} \\
\hline & Sample G348 & (1.21) & & & \\
\hline & Semple G349 & $(1.20)$ & & & \\
\hline & Somple G352 & $(1.20)$ & & & \\
\hline & Sample G353 & $(1.20)$ & & & \\
\hline & Sample G358 & $(1.20)$ & & & \\
\hline & Sample $\mathbf{6 3 5 9}$ & $(1.20)$ & & & \\
\hline & Sample G363 & $\{1.20\}$ & & & \\
\hline & Sample G364 & (1.19) & & & \\
\hline & Sample G459 & $(1.20)$ & & & \\
\hline & Sample G460 & $(1.20)$ & & & \\
\hline & Sample G341 & $(1.20)$ & & & \\
\hline & Sample G443 & $(1.20)$ & & & \\
\hline
\end{tabular}

Table A-5. Tank 241-AP-102 Analytical Data: Total Inorganic Carbon

\begin{tabular}{|c|c|c|c|c|c|c|}
\hline Analyte & $\begin{array}{l}\text { Laboratory } \\
\text { Sample } \\
\text { Identification }\end{array}$ & $\begin{array}{c}\text { Anafytical } \\
\text { Data } \\
\text { Restit }\end{array}$ & $\begin{array}{c}\text { Range } \\
\text { of } \\
\text { Values }\end{array}$ & Statistical Mean & $\begin{array}{c}\text { Standard Error } \\
\text { [Mean] }\end{array}$ & $\begin{array}{l}\text { Projected } \\
\text { Inventory }\end{array}$ \\
\hline $\begin{array}{l}\text { Physical } \\
\text { Property }\end{array}$ & & $\mu \mathrm{g} / \mathrm{mL}$ & $\mu \mathrm{g} / \mathrm{mL}$ & $\mu \mathrm{g} / \mathrm{mL}$ & $\mu \mathrm{g} / \mathrm{mL}$ & kg \\
\hline \multirow[t]{14}{*}{ COUL.TIC } & Sample G342 & $(5,540)$ & \multirow{14}{*}{$\begin{array}{c}4,760 \\
\text { to } \\
5,880\end{array}$} & \multirow[t]{14}{*}{5.350} & \multirow[t]{14}{*}{111} & \multirow[t]{14}{*}{22,400} \\
\hline & Sample G348 & $(5,110)$ & & & & \\
\hline & Sample G349 & $(5,190)$ & & & & \\
\hline & Sample G352 & $(5,290)$ & & & & \\
\hline & Sample $\mathbf{G 3 5 3}$ & $(5,150)$ & & & & \\
\hline & Sample G35B & $(5,230)$ & & & & \\
\hline & Sample G359 & $(5,700)$ & & & & \\
\hline & Sample 6363 & $(5,330)$ & & & & \\
\hline & Sample G364 & $(5,860)$ & & & & \\
\hline & Sample G333 & $(5,060)$ & & & & \\
\hline & Sample G459 & $(4,850)$ & & & & \\
\hline & Sample 6460 & $(4,760)$ & & & & \\
\hline & Sample G338 & $(5,130)$ & & & & \\
\hline & Sample G341 & $(5, e 40)$ & & & & \\
\hline
\end{tabular}


Table A-5. Tank 241-AP-102 Analytical Data: Total Organic Carbon

\begin{tabular}{|c|c|c|c|c|c|c|}
\hline कAndre & $\begin{array}{l}\text { Laboratofy } \\
\text { Sample } \\
\text { Wertifiction }\end{array}$ & $\begin{array}{l}\text { Andyted } \\
\text { Dotat }\end{array}$ & $\begin{array}{l}\text { honoe } \\
\text { yol }\end{array}$ & Striftical Mos & Whider & $\begin{array}{l}\text { Projectod } \\
\text { inventory }\end{array}$ \\
\hline $\begin{array}{l}\text { Ptryicel } \\
\text { Property }\end{array}$ & & $\omega / \mathrm{mL}$ & $\mu v / m L$ & $\mu \mathrm{g} / \mathrm{mL}$ & $\mu \mathrm{g} / \mathrm{mL}$ & $\mathbf{k g}$ \\
\hline \multirow[t]{13}{*}{ COUL.TOC } & Sample $\mathbf{6 3 4 2}$ & $(3,180)$ & \multirow{13}{*}{$\begin{array}{c}3,060 \\
t 0 \\
3,480\end{array}$} & \multirow[t]{13}{*}{3,280} & \multirow[t]{13}{*}{42.2} & \multirow[t]{13}{*}{13,700} \\
\hline & Semple G348 & $(3,240)$ & & & & \\
\hline & Sample G349 & $(3,060)$ & & & & \\
\hline & Sample $\mathbf{G 3 5 2}$ & $(3,340)$ & & & & \\
\hline & Sample G353 & $(3,340)$ & & & & \\
\hline & Sample G358 & $(3,480)$ & & & & \\
\hline & Sample G359 & $(3,420)$ & & & & \\
\hline & Sample G363 & $(3,180)$ & & & & \\
\hline & Sample G364 & $(3,440)$ & & & & \\
\hline & Sample G459 & $(3,060)$ & & & & \\
\hline & Sample G460 & $(3,290)$ & & & & \\
\hline & Sample G341 & $(3,320)$ & & & & \\
\hline & Sample G443 & $(3,240)$ & & & & \\
\hline
\end{tabular}


Table A-6. Tank 241-AP-102 Analytical Data: Volatile Organic Analyses

\begin{tabular}{|c|c|c|c|}
\hline 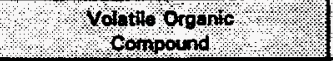 & 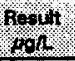 & $\begin{array}{l}\text { Volatie orpenis } \\
\text { Compound }\end{array}$ & topt \\
\hline Chloromethane & ND & Bromotorm & ND \\
\hline Bromomethane & ND & 4-Methyl-2-Pentanone & ND \\
\hline Vinyl Chloride & ND & 2-Hexanone & ND \\
\hline Chloroethene & ND & Tetrochloroethene & ND \\
\hline Methylene Chloride & ND & 1,1,2,2-Tetrechlorcethane & ND \\
\hline Acetone & ND & Toluane & ND \\
\hline Carbon Disulfide & ND & Chlorobenzene & ND \\
\hline 1,1-Dichioroethene & ND & Ethlybenzerse & ND \\
\hline 1,1-Dichloroethane & ND & Styrene & ND \\
\hline trans-1,2-Dichloroethene & ND & m\&p-Xylene & ND \\
\hline cis-1,2-Dichloroethene & ND & o-Xylene & ND \\
\hline Chloroform & ND & Isopropylbenzene & ND \\
\hline 1,2-Dichloroethane & ND & 1,3,5-Trimethylbenzene & ND \\
\hline 2-Butanone & ND & 1,2,4-Trimethylbenzene & ND \\
\hline 1,1,1-Trichloroethane & ND & 1,2,3-Trime thylbenzene & ND \\
\hline Carbon Tetrachloride & ND & Dibromochloromethane & ND \\
\hline Vinyl Acetate & ND & 1,1,2.Trichloroethane & ND \\
\hline Bromodichloromethane & ND & Benzene & ND \\
\hline 1,2-Dichloropropane & ND & trans-1,3-Dichloropropene & ND \\
\hline cis-1,3-Dichloropropene & ND & Trichloroethene & ND \\
\hline
\end{tabular}


Table A-7. Tank 241-AP-102 Analytical Data: Semivolatile Organic Analyses

\begin{tabular}{|c|c|c|c|}
\hline Somivolathe Organic & pesult & औ. Semivolatile Organic & presils \\
\hline 1-Butanol & ND & 2,4,6-Trichlorophenol & ND \\
\hline Pyridine & ND & 2,4,5-Trichlorophenol & ND \\
\hline Phend & ND & 2-Chloronaphthalene & No \\
\hline bis(2-Chlorcethyl)ether & ND & 2-Nitroaniline & ND \\
\hline 2-Chlorophenol & ND & Dimothylphthalate & ND \\
\hline 1,3-Dichlorobenzene & ND & Acenaphthylene & No \\
\hline 1,4-Dichlorobenzene & ND & 2,6-Dinitrotoluene & ND \\
\hline Benzyl alcohol & ND & 3-Nitroaniline & ND \\
\hline 1,2-Dichlorobenzene & ND & Acenaphthene & ND \\
\hline 2-Methylphenol & ND & 2,4-Dinitrophenol & ND \\
\hline bis (2-Chloroisopropyl)ether & ND & 4-Nitrophenol & ND \\
\hline 4-Methylphenol & ND & Dibenzofuran & ND \\
\hline N-Nitroso-di-n-propylamine & ND & 2,4-Dinitrotoluene & ND \\
\hline Hexachloroethane & ND & Diethylphthalate & ND \\
\hline Nitrobenzene & ND & 4-Chlorophenyl-phenylether & ND \\
\hline Isophorone & ND & Flourene & ND \\
\hline 2-Nitropheno! & ND & 4-Nitroanaline & ND \\
\hline 2,4-Dimethylphenol & ND & 4,6-Dinitro-2-methylohenol & ND \\
\hline Benzoic acid & ND & N-Nitrosodiphenylamine & ND \\
\hline bis(2-Chloroethoxy)methane & ND & Tributylphosphate & ND \\
\hline 2,4-Dichlorophenol & ND & 4-Bromophenyl-phenylether & ND \\
\hline 1,2,4-Trichioroberzene & ND & Hexachlotoberzene & ND \\
\hline Naphthalene & ND & Pentachlorophenol & ND \\
\hline 4-Chloroaniline & ND & Phenanthrene & NO \\
\hline Hexachlorobutadiene & ND & Anthracene & ND \\
\hline 4-Chloro-3-methylphenol & ND & Din-butylphthalate & ND \\
\hline 2-Methylnaphthaiene & ND & Fluoranthene & ND \\
\hline Hexachlorocyclopentadiene & ND & Pyrene & ND \\
\hline Butylbenzylphthalate & ND & Benzo(b)fluoranthene & ND \\
\hline 3.3'-Dichlorobenzidine & ND & Benzo(k)fluoranthene & ND \\
\hline Benzo(a)anthracene & ND & Benzola)pyrene & ND \\
\hline Chrysene & ND & Indeno $\{1,2,3$-cd)pyrene & ND \\
\hline Bis (2-Ethylhexyliphthalate & ND & Dibenz $(a, h)$ anthracene & ND \\
\hline Di-n-octylphthalate & ND & Benzolg,h,i)perylene & ND \\
\hline
\end{tabular}


Table A-8. Tank 241-AP-102 Analytical Data: Acetone

\begin{tabular}{|c|c|c|c|c|c|c|}
\hline Anqlyte & $\begin{array}{l}\text { Laborton } \\
\text { Sanple } \\
\text { dofifitation }\end{array}$ & $\begin{array}{l}\text { Analytical } \\
\text { Data } \\
\text { nosuth }\end{array}$ & $\begin{array}{l}\text { Panos } \\
\text { of } \\
\text { Yolues }\end{array}$ & bopepton L fint & $\begin{array}{l}\text { Stindard } \\
\text { Eror } \\
\text { Woand }\end{array}$ & 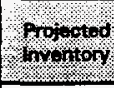 \\
\hline Organic & & $\mu g \Omega$ & $\mu g h$ & $\mu \boldsymbol{\rho} \Omega$ & $\mu / L$ & kg \\
\hline \multirow{8}{*}{$\begin{array}{l}\text { VOA. } \\
\text { Acetone }\end{array}$} & Sample G300 & $<500$ & \multirow{8}{*}{$\begin{array}{c}230 \\
\text { to } \\
<500\end{array}$} & \multirow[t]{8}{*}{$<500$} & \multirow[t]{8}{*}{ N/A } & \multirow[t]{8}{*}{2.09} \\
\hline & Semple G304 & $<500$ & & & & \\
\hline & Sample G312 & $<500$ & & & & \\
\hline & Sample G314 & 230 & & & & \\
\hline & Sample G3T4D & $<500$ & & & & \\
\hline & Sample G316 & $<500$ & & & & \\
\hline & Sample G320 & $<500$ & & & & \\
\hline & Sample G321 & $<500$ & & & & \\
\hline
\end{tabular}

Table A-8. Tank 241-AP-102 Analytical Data: 1-Butanol

\begin{tabular}{|c|c|c|c|c|c|c|}
\hline Anatyte & $\begin{array}{c}\text { Laboratory } \\
\text { Sample } \\
\text { Identification }\end{array}$ & $\begin{array}{c}\text { Analytical } \\
\text { Data } \\
\text { Result }\end{array}$ & $\begin{array}{c}\text { Range } \\
\text { of } \\
\text { Vałues }\end{array}$ & $\begin{array}{l}\text { Simple } \\
\text { Mean }\end{array}$ & $\begin{array}{l}\text { Standard } \\
\text { Error } \\
\text { (Mean) }\end{array}$ & $\begin{array}{l}\text { Projected } \\
\text { inventory }\end{array}$ \\
\hline Organic & & $\mu g / \mathrm{L}$ & $\mu g / \Omega$ & $\mu g /$ & $\mu g / L$ & $\mathrm{~kg}$ \\
\hline \multirow{10}{*}{$\begin{array}{r}\text { SVOA. } \\
\text { 1-Butanol }\end{array}$} & Sample G300-1 & 370 & \multirow{10}{*}{$\begin{array}{l}370 \\
\text { to } \\
820\end{array}$} & \multirow[t]{10}{*}{618} & \multirow[t]{10}{*}{ N/A } & \multirow[t]{10}{*}{2.58} \\
\hline & Sample G300-2 & 470 & & & & \\
\hline & Sample G304 & $<1000$ & & & & \\
\hline & Sample 6312 & 750 & & & & \\
\hline & Sample G314 & 820 & & & & \\
\hline & Sample G316-1 & 600 & & & & \\
\hline & Sample G316-2 & 690 & & & & \\
\hline & Sample G320 & 730 & & & & \\
\hline & Sample G321 & 510 & & & & \\
\hline & Sample G324 & $<1000$ & & & & \\
\hline
\end{tabular}


WHC-SD-WM-ER-358 REV O

Table A-8. Tank 241-AP-102 Analytical Data: 2-Butanone

\begin{tabular}{|c|c|c|c|c|c|c|}
\hline Analyte & $\begin{array}{l}\text { Laboratory } \\
\text { Sample } \\
\text { Identifertion }\end{array}$ & $\begin{array}{c}\text { Analytical } \\
\text { Data } \\
\text { Resuti }\end{array}$ & $\begin{array}{l}\text { Range } \\
\text { of of } \\
\text { Yalus }\end{array}$ & 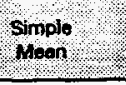 & $\begin{array}{l}\text { Standard } \\
\text { Eror } \\
\text { (Nol }\end{array}$ & $\begin{array}{l}\text { Proiectod } \\
\text { Ioverpten }\end{array}$ \\
\hline Orgaric & $\cdot$ & $\mu g$ & $\mu \theta \Omega$ & $\mu g /$ & $\mu g /$ & $\mathbf{k g}$ \\
\hline \multirow{8}{*}{$\begin{array}{l}\text { VOA. } \\
\text { 2-Butanone }\end{array}$} & Sample G300 & $<500$ & \multirow{8}{*}{$\begin{array}{c}<500 \\
\text { to } \\
590\end{array}$} & \multirow[t]{8}{*}{$<500$} & \multirow[t]{8}{*}{$N / A$} & \multirow[t]{8}{*}{2.09} \\
\hline & Sample G304 & $<500$ & & & & \\
\hline & Sample G312 & $<500$ & & & & \\
\hline & Sample G314 & 590 & & & & \\
\hline & Sample G314D & $<500$ & & & & \\
\hline & Sample G316 & $<500$ & & & & \\
\hline & Sample G320 & $<500$ & & & & \\
\hline & Sample G321 & $<500$ & & & & \\
\hline
\end{tabular}

Table A-8. Tank 241-AP-102 Analytical Data: Toluene

\begin{tabular}{|c|c|c|c|c|c|c|}
\hline Analyte & $\begin{array}{l}\text { Laboratory } \\
\text { Sample } \\
\text { Identification }\end{array}$ & $\begin{array}{c}\text { Analytical } \\
\text { Data } \\
\text { Result }\end{array}$ & $\begin{array}{c}\text { Range } \\
\text { of } \\
\text { Values }\end{array}$ & $\begin{array}{l}\text { Simple } \\
\text { Mean }\end{array}$ & $\begin{array}{l}\text { Standard } \\
\text { Error } \\
\text { (Mean) }\end{array}$ & $\begin{array}{l}\text { Projected } \\
\text { Inventory }\end{array}$ \\
\hline Organic & & $\mu g / L$ & $\mu g / L$ & $\mu g / L$ & $\mu g / L$ & $\mathbf{k g}$ \\
\hline \multirow{8}{*}{$\begin{array}{l}\text { VOA. } \\
\text { Toluene }\end{array}$} & Sample G300 & $<500$ & \multirow{8}{*}{$\begin{array}{l}43 \\
\text { to } \\
<500\end{array}$} & \multirow[t]{8}{*}{$<500$} & \multirow[t]{8}{*}{ N/A } & \multirow[t]{8}{*}{2.09} \\
\hline & Sample G304 & $<500$ & & & & \\
\hline & Sample G312 & $<500$ & & & & \\
\hline & Sample G314 & 140 & & & & \\
\hline & Sample G314D & $<500$ & & & & \\
\hline & Sample 6316 & 43 & & & & \\
\hline & Sample G320 & $<500$ & & & & \\
\hline & Sample G321 & $<500$ & & & & \\
\hline
\end{tabular}



WHC-SD-WM-ER-358 REV O

Appendix B. Statistical Analysis Presentation 
, 


\section{B.1 The ANOVA Model (Welsh 1993)}

This appendix contains a description of the statistical model that describes the structure of the data from supernate samples taken from Tank 241-102-AP. Equations are also presented for estimates of the mean concentration, the variance for the mean concentration, and the confidence intervals on the mean concentration.

The statistical model that describes the structure of the data is

$$
y_{i j k}=\mu+L_{i}+B_{i j}+A_{i j k}, i=1, \ldots a, j=1, \ldots b_{i}, k=1, \ldots n_{i j} \text {, }
$$

where

$$
\begin{aligned}
& y_{i j k}=\quad \begin{array}{l}
\text { laboratory results from the } k^{\text {th }} \text { dupicate of the } j^{\text {th }} \text { bottle } \\
\text { of the } i^{\text {th }} \text { location in the tank, }
\end{array} \\
& L_{i}=\begin{array}{l}
\text { the grand mean of all the data, } \\
\text { the effect of the } i^{\text {th }} \text { location (measuring spatial } \\
\text { variability). }
\end{array} \\
& B_{i j}=\begin{array}{l}
\text { the effect of the } j^{\text {th }} \text { bottle at the } i^{\text {th }} \text { location (measuring } \\
\text { local sampling variability), and }
\end{array} \\
& A_{i j k}=\begin{array}{l}
\text { the analytical error associated with the } k^{\text {th }} \text { duplicate in } \\
\text { the } j^{\text {th }} \text { bottle in the } i^{\text {th }} \text { location. }
\end{array}
\end{aligned}
$$

For the inorganic and radiological analytes, there are generaliy only three tank locations that have duplicate bottles and all others locations have one bottle (i.e., $b_{i}=1$ or 2 ). Reruns of the samples and duplicates (within each bottle) were obtained for some of the locations (i.e., $n_{i} ;=2,4$ or 6 ).

$L_{i}$ and $B_{i j}$ are treated as random effects. It is assumed that $L_{i}, B_{i j}$ and $A_{i j k}$ are each distributed normally with mean zero and a variances $\sigma_{l}^{2}, " \sigma_{B}^{2}$, and $\sigma_{A}^{A_{i j k}}$, respectively. Estimates of $\sigma_{L}^{2}, \sigma_{B}^{2}$, and $\sigma_{A}^{2}$ were obtained using Restricted Maximum Likelihood Estimation (REML). "This method applied to variance component estimation is described by Harville (1977).

The mean concentration of each analyte of interest in the tank was calculated using the following equation:

$$
\bar{y}_{r}=\frac{\sum_{i=1}^{a} \bar{y}_{i} .}{a}=\frac{\sum_{i=1}^{a} \frac{\sum_{j=1}^{b_{i}} \sum_{k=1}^{n_{i j}} y_{i j k}}{b_{i}} \sum_{j=1}^{a} n_{i j} \frac{\sum_{i=1}^{b_{i}} \sum_{k=1}^{n_{j j}}\left(\mu+L_{i}-B_{i j}+A_{i j k}\right)}{b_{i}}}{a}=\frac{\sum_{i=1}^{b_{i}} n_{i j}}{a}
$$


The variance of $\bar{y}_{1}$ is

$$
V\left(\vec{y}_{1}\right)=C_{1} \sigma_{L}^{2}+C_{2} \sigma_{B}^{2}+C_{3} \sigma_{A}^{2}
$$

where

$$
\left.c_{1}=\frac{1}{a}, c_{2}=\sum_{i=1}^{2} \frac{\left(\left[\sum_{j=1}^{b_{i}} n_{i j} n_{i j}^{2}\right.\right.}{a^{2}}\right], \quad c_{3}=\sum_{i=1}^{\infty} \frac{\left(\sum_{j=1}^{b_{i=1}} n_{i j} n_{i j}\right)^{2}}{a^{2}}
$$

Using $\hat{\sigma}_{L}^{2}, \hat{\sigma}_{B}^{2}$, and $\hat{\sigma}_{A}^{2}$ (REML variance component estimates), an estimated variance of $\bar{y}_{T}$ is

$$
\dot{\sigma}^{2}\left(\bar{y}_{1}\right)=C_{1} \dot{\sigma}_{L}^{2}+C_{2} \dot{\sigma}_{B}^{2}+C_{3} \dot{\sigma}_{A}^{2}
$$

The approximate degrees of freedom used for $\dot{\sigma}^{2}\left(\bar{y}_{T}\right)$ is the number of locations sampled minus one (which varies for each analyte).

A 95\%. two-sided confidence interval on the mean concentration $\left(\bar{y}_{1}\right)$ for a given analyte is

$$
\bar{y}_{T} \pm t_{.9 \pi s} \sqrt{\tilde{\sigma}^{2}\left(\bar{y}_{T}\right)}
$$

where $t .97$ is the .975 quantile from a Student's $t$-distribution with the approximate degrees of freedom associated with $\hat{\sigma}^{2}\left(\bar{y}_{T}\right)$.

A $95 \%$ upper-tailed confidence interval on $\bar{y}_{T}$ is

$$
\bar{y}_{T}+t_{.95} \sqrt{\dot{\sigma}^{2}\left(\bar{y}_{\mathrm{r}}\right)}
$$

where $t .95$ is the .95 quantile from a student's t-distribution with the approximate degrees of freedom associated with $\dot{\sigma}^{2}\left(\bar{y}_{1}\right)$. 